\title{
Abiotic Degradation Rates for Carbon Tetrachloride and Chloroform: Final Report
}

\author{
JE Amonette \\ PM Jeffers \\ O Qafoku \\ CK Russell \\ DR Humphrys \\ TW Wietsma \\ MJ Truex
}

December 2012

\section{Pacific Northwest}

NATIONAL LABORATORY

Proudly Operated by Battelle Since 1965 



\title{
DISCLAIMER
}

This report was prepared as an account of work sponsored by an agency of the United States Government. Neither the United States Government nor any agency thereof, nor Battelle Memorial Institute, nor any of their employees, makes any warranty, express or implied, or assumes any legal liability or responsibility for the accuracy, completeness, or usefulness of any information, apparatus, product, or process disclosed, or represents that its use would not infringe privately owned rights. Reference herein to any specific commercial product, process, or service by trade name, trademark, manufacturer, or otherwise does not necessarily constitute or imply its endorsement, recommendation, or favoring by the United States Government or any agency thereof, or Battelle Memorial Institute. The views and opinions of authors expressed herein do not necessarily state or reflect those of the United States Government or any agency thereof.

\author{
PACIFIC NORTHWEST NATIONAL LABORATORY \\ operated by \\ BATTELLE \\ for the \\ UNITED STATES DEPARTMENT OF ENERGY \\ under Contract DE-AC05-76RL01830
}

Printed in the United States of America

$$
\begin{aligned}
& \text { Available to DOE and DOE contractors from the } \\
& \text { Office of Scientific and Technical Information, } \\
& \text { P.O. Box } 62 \text {, Oak Ridge, TN } 37831-0062 \text {; } \\
& \text { ph: }(865) 576-8401 \\
& \text { fax: }(865) 576-5728 \\
& \text { email: reports@adonis.osti.gov }
\end{aligned}
$$

Available to the public from the National Technical Information Service 5301 Shawnee Rd., Alexandria, VA 22312 ph: (800) 553-NTIS (6847)

email: orders antis.gov <http://www.ntis.gov/about/form.aspx> Online ordering: http://www.ntis.gov 

PNNL-22062

RPT-DVZ-AFRI-012

\section{Abiotic Degradation Rates for Carbon Tetrachloride and Chloroform: Final Report}

JE Amonette

PM Jeffers ${ }^{1}$

O Qafoku

CK Russell

DR Humphrys

TW Wietsma

MJ Truex

December 2012

Prepared for

the U.S. Department of Energy

under Contract DE-AC05-76RL01830

Pacific Northwest National Laboratory

Richland, Washington 99352

\footnotetext{
${ }^{1}$ The Research Foundation of the State University of New York, Cortland, New York.
} 



\section{Abstract}

Between 1955 and 1973, an estimated 920,000 kg of carbon tetrachloride (CT) were discharged to the soil in the 200 West Area of the Hanford Site as part of the plutonium production process. Of this amount, some CT reached the groundwater more than $70 \mathrm{~m}$ below the ground surface and formed a plume of $10 \mathrm{~km}^{2}$ extent. Remediation of the CT plume is underway using a pump-and-treat approach to reduce concentrations of $\mathrm{CT}$ and other contaminants such as chloroform (CF) and radionuclides in the aquifer over a projected 25-year operational period. Following the period of pump-and-treat operation, monitored natural attenuation will be the continuing remedy to reach groundwater remediation goals. Multiple mechanisms of natural attenuation can reduce CT and CF concentrations over time during pumpand-treat and the subsequent monitored natural attenuation remedy phases. Of these attenuation mechanisms, hydrolysis reactions are expected to contribute as a degradation process for CT and CF. This report documents the results of long-term experiments to quantify the homogeneous and heterogeneous hydrolysis rates for CT and CF needed to estimate the contribution of hydrolysis to natural attenuation of the contaminant plumes under the subsurface conditions at the Hanford Site (e.g., temperature and sediment mineralogy). Experiments were conducted across a temperature range of $20^{\circ}-$ $93^{\circ} \mathrm{C}$ for periods as long as 6 years, and the Arrhenius equation was used to estimate activation energies and calculate half-lives for typical Hanford groundwater conditions (temperature of $16^{\circ} \mathrm{C}$ and $\mathrm{pH}$ of 7.75). A half-life of 630 years for hydrolysis for $\mathrm{CT}$ under these conditions was estimated, where CT hydrolysis was unaffected by contact with sterilized, oxidized minerals or Hanford sediment within the sensitivity of the experiments. In contrast to CT, hydrolysis of CF was generally slower and very sensitive to $\mathrm{pH}$ due to the presence of both neutral and base-catalyzed hydrolysis pathways. A half-life of 3400 years was estimated for hydrolysis of $\mathrm{CF}$ in homogeneous solution at $16^{\circ} \mathrm{C}$ and $\mathrm{pH} 7.75$. Experiments with CF in suspensions of Hanford sediment or smectite, the dominant clay mineral in Hanford sediment, equilibrated to an initial $\mathrm{pH}$ of 7.2, yielded calculated half-lives of 1700 years and 190 years, respectively, at $16^{\circ} \mathrm{C}$. Experiments for $\mathrm{CF}$ with three other mineral phases at the same $\mathrm{pH}$ (muscovite mica, albite feldspar, and kaolinite) showed no change from the homogeneous solution results (i.e., a half-life of 3400 years). The strong influence of Hanford sediment on CF hydrolysis was attributed to the presence of smectite and its ability to adsorb protons, thereby buffering the solution $\mathrm{pH}$ at a higher level than would otherwise occur. 


\section{Acknowledgments}

During the first three years, this work was funded as two separate projects by various sponsors, all of whom received their funding from the U.S. Department of Energy (DOE), and involved a funded collaboration with staff from the State University of New York at Cortland (SUNY-Cortland). In fiscal year (FY) 2009, the two projects were combined and funded by CH2M HILL Plateau Remediation Company through FY 2011 and the funded collaboration with SUNY-Cortland was ended. In FY 2012, the combined project was funded directly by the DOE Richland Operations office as part of the Deep Vadose Zone - Applied Research Initiative. The Pacific Northwest National Laboratory is operated by Battelle Memorial Institute for the DOE under Contract DE-AC05-76RL01830. 


\section{Abbreviations}

$\begin{array}{ll}\text { CF } & \text { chloroform } \\ \text { CT } & \text { carbon tetrachloride } \\ \text { DOE } & \text { U.S. Department of Energy } \\ \text { FY } & \text { fiscal year } \\ \text { GC } & \text { gas chromatography } \\ \text { IC } & \text { ion chromatography } \\ \text { PCE } & \text { perchloroethene } \\ \text { PFO } & \text { pseudo-first-order } \\ \text { PNNL } & \text { Pacific Northwest National Laboratory } \\ \text { SUNY-Cortland } & \text { State University of New York at Cortland } \\ \text { ZHR } & \text { zero-headspace reactor }\end{array}$




\section{Symbols}

$\begin{array}{ll}\mathrm{A} & \text { Arrhenius pre-exponential factor } \\ \mathrm{CL}_{ \pm 95 \%} & \pm 95 \% \text { confidence interval } \\ \mathrm{cm} & \text { centimeter } \\ \mathrm{E}_{\mathrm{a}} & \text { activation energy } \\ \mathrm{in} & \text { inch } \\ \mathrm{K}_{\mathrm{H}}{ }^{\prime} & \text { dimensionless Henry's law constant } \\ \mathrm{K}_{\mathrm{lv}} & \text { dimensionless liquid-vapor partition coefficient } \\ \mathrm{k}_{\mathrm{app}} & \text { apparent rate constant } \\ \mathrm{k}_{\mathrm{B}} & \text { base-catalyzed rate constant for CF hydrolysis } \\ \mathrm{k}_{\mathrm{N}} & \text { neutral rate constant for CF hydrolysis } \\ \mathrm{k}_{\mathrm{pfo}} & \text { pseudo-first-order rate constant for CF hydrolysis } \\ \mathrm{k}_{\mathrm{zhs}} & \text { rate constant normalized to zero headspace } \\ \mathrm{kg} & \text { kilogram } \\ \mathrm{L} & \text { liter } \\ \mathrm{m} & \text { meter } \\ \mathrm{M} & \text { molar } \\ \mathrm{mg} & \text { milligram } \\ \mathrm{mm} & \text { millimeter } \\ \mathrm{mM} & \text { millimolar } \\ \mathrm{mol} & \text { mole } \\ \mathrm{ppm} & \text { parts-per-million } \\ \mathrm{R} & \text { gas constant } \\ \mathrm{RC} & \text { relative confidence in rate constant, k } \\ \mathrm{s} & \text { second } \\ \mathrm{t}_{\mathrm{k}} & \text { half life } \\ \mathrm{T} & \text { temperature } \\ \mu \mathrm{g} & \text { microgram } \\ \mathrm{V}_{\mathrm{l}} & \text { volume of liquid in sealed reaction vessel } \\ \mathrm{V}_{\mathrm{v}} & \text { volume of headspace in sealed reaction vessel } \\ & \end{array}$




\section{Contents}

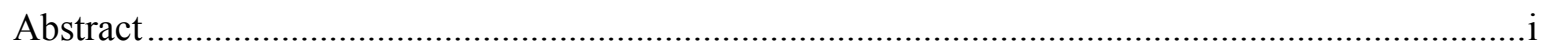

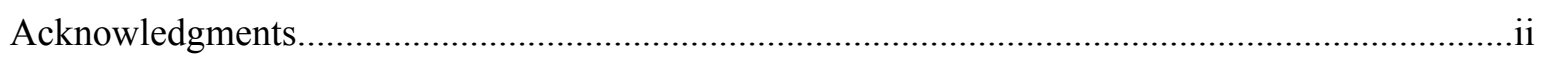

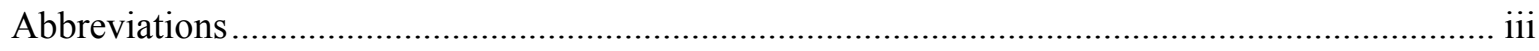

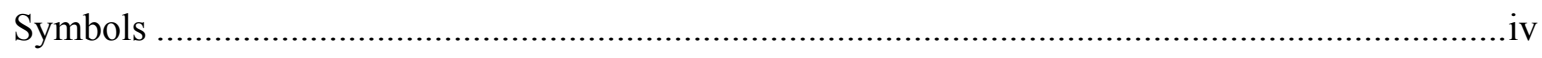

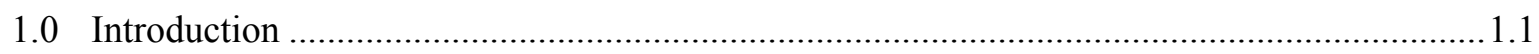

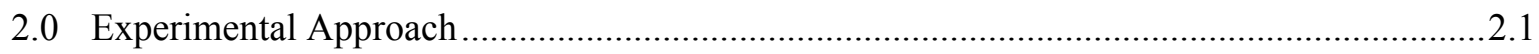

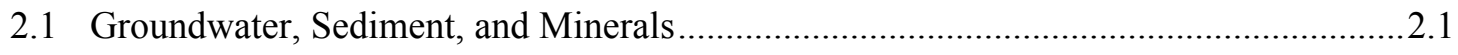

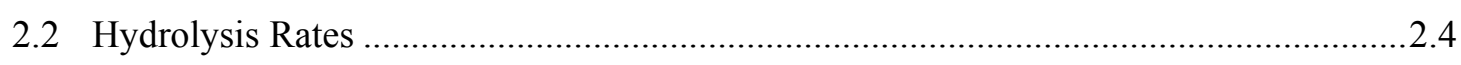

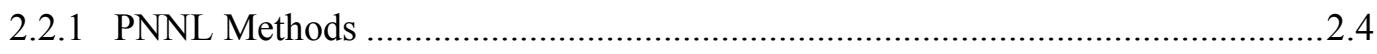

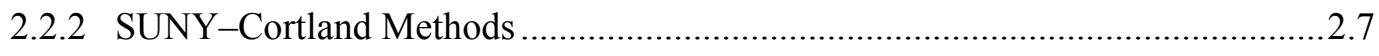

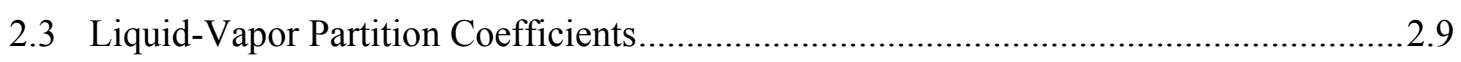

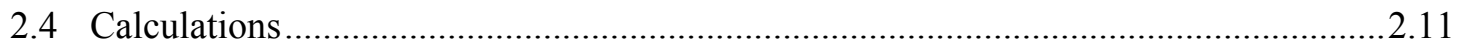

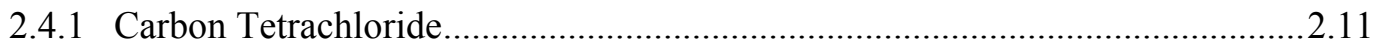

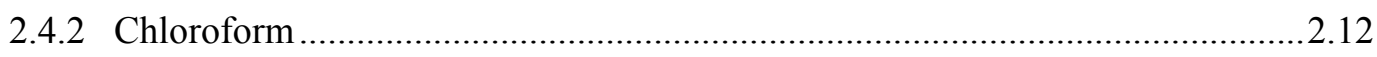

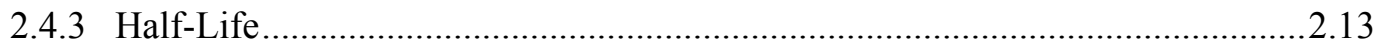

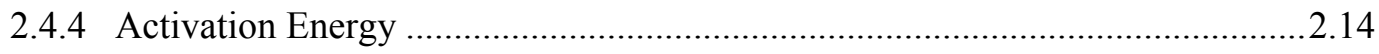

2.4.5 Correction to Zero Headspace ................................................................... 2.14

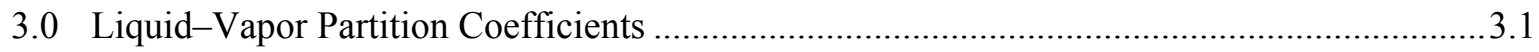

4.0 Hydrolysis Rate Experiments ...................................................................................... 4.1

4.1 Homogeneous Experiments with Carbon Tetrachloride ............................................... 4.1

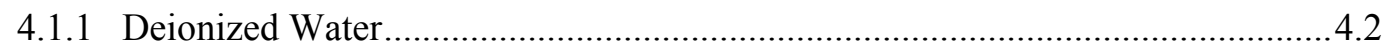

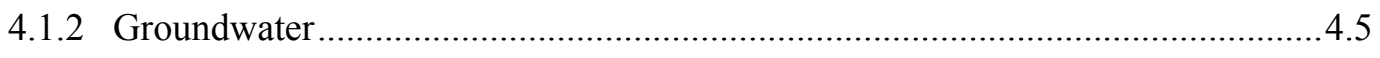

4.1.3 Summary of Homogeneous Results for Carbon Tetrachloride …........................4.6

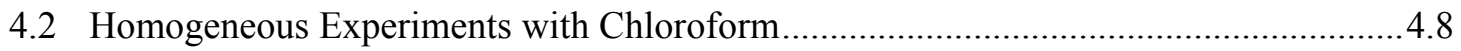

4.3 Heterogeneous Experiments with Carbon Tetrachloride .......................................... 4.12

4.4 Heterogeneous Experiments with Chloroform ........................................................ 4.15

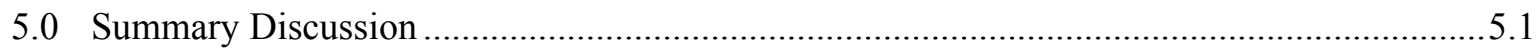

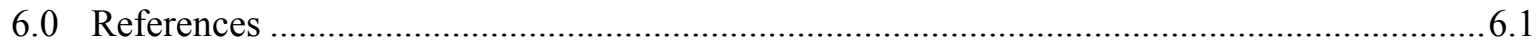




\section{Figures}

Figure 2.1. Ampule (left) and Automatic Ampule Sealer (right) Used for PNNL Hydrolysis Experiments.

Figure 2.2. Set of Ampules in Rack (top left) Ready for Insertion into Incubator (bottom left) and Incubator Array Used in PNNL Experiments (right).

Figure 2.3. Zero-Headspace Reactor (top) and Apparatus for Determination of Liquid-Vapor Partition Coefficients (bottom) Fabricated and Used for Hydrolysis Experiments at SUNY-Cortland.

Figure 2.4. Infrared Gas Cell and Spectrometer Used in the Liquid-Vapor Partition Coefficient Determinations at PNNL.

Figure 2.5. Plot of Typical Absorbance Data for Successive Equilibrations of CT in the Partition

Coefficient Determination.

Figure 2.6. Linear Relation Between Log of Absorbance and Equilibration Number.

Figure 3.1. Values of $\mathrm{K}_{\mathrm{H}}$ for Carbon Tetrachloride Determined and Extrapolated to Higher Temperatures from Gossett (1987) and Staudinger and Roberts (2001), Together with Empirical Determinations of $\mathrm{K}_{\mathrm{lv}}$ at SUNY-Cortland and PNNL by Measurements in the Aqueous and Vapor Phases, Respectively.

Figure 3.2. Mean Values of $\mathrm{K}_{\mathrm{lv}}$ for Chloroform Measured by SUNY-Cortland and PNNL, Together with $\mathrm{K}_{\mathrm{h}}$ Values for Chloroform Reported by Gorgenyi et al. (2002) and Predicted by the Staudinger and Roberts (2001) Equation.

Figure 4.1. Arrhenius Plot of $\mathrm{k}_{\mathrm{zhs}}$ Data for Deionized Water Generated in This Study Along with $\mathrm{k}_{\mathrm{app}}$ Data as Reported by Jeffers et al. (1996) and the 1996 Data Normalized to $\mathrm{k}_{\mathrm{zhs}}$ Assuming a 2\% Headspace-to-Liquid Ratio and the Extrapolated Values of $\mathrm{K}_{\mathrm{lv}}$ (Table 4.3). Blue Triangles are SUNY Data for Deionized Water Using Zero-Headspace Reactors.

Figure 4.2. Arrhenius Plot of All Robust $\mathrm{k}_{\mathrm{zhs}}$ Data for Carbon Tetrachloride Hydrolysis in Deionized Water (DI) and Hanford Groundwater (HGW) Generated in This Study at SUNY-Cortland (SUNY) and PNNL. Error Bars are 95\% Confidence Intervals.

Figure 4.3. Arrhenius Plot of All Homogeneous Hydrolysis Data $\left(\mathrm{k}_{\mathrm{zhs}}\right)$ for Chloroform. Error bars represent $\pm 95 \%$ confidence intervals. White triangle is $\mathrm{pH} 3$ datum not included in Arrhenius regression.

Figure 4.4. Arrhenius Plot of Base-Catalyzed Homogeneous Hydrolysis Data $\left(\mathrm{k}_{\mathrm{zhs}}\right)$ for Chloroform.

Figure 4.5. Impact of Temperature and $\mathrm{pH}$ on Hydrolysis Half-life Predicted for Chloroform From Homogeneous Rate Data Developed in This Project.

Figure 4.6. Arrhenius Plot of $\mathrm{k}_{\mathrm{zhs}}$ Data for Hydrolysis of Carbon Tetrachloride in Deionized Water, Hanford Groundwater, and Suspensions of Oxidized Hanford Sediment in Hanford Groundwater. Error Bars are 95\% Confidence Intervals.

Figure 4.7. Arrhenius Plot of Observed Pseudo-First-Order Rate Data $\left(\mathrm{k}_{\mathrm{pfo}}\right)$ for Hydrolysis of Chloroform in Suspensions of Minerals or Hanford Sediment and Calculated for Homogeneous Solutions at Several $\mathrm{pH}$ Levels. White circle is datum not included in Arrhenius regression for Hanford sediment. Error Bars are 95\% Confidence Intervals. ..4.18 


\section{Tables}

Table 2.1. Typical Composition and Chemical Properties of Hanford Groundwater from Well 699-49-100C

Table 2.2. Texture and Mineralogy of Hanford Sediment

Table 2.3. Minerals Used in Heterogeneous Experiments and Their Source Locales

Table 4.1. Conditions for Homogeneous Carbon Tetrachloride Hydrolysis Experiments and the Relative Confidence of the Rate Constants Obtained.

Table 4.2. Rate Constants for Hydrolysis of Carbon Tetrachloride in Deionized Water.

Table 4.3. Rate Constants for Hydrolysis of Carbon Tetrachloride in Deionized Water at High Temperatures as Reported by Jeffers et al. (1996) $\left(\mathrm{k}_{\mathrm{app}}\right)$ and as Corrected for an Assumed $2 \%$ Headspace-to-Liquid Ratio Using Extrapolated Values of $\mathrm{K}_{\mathrm{lv}}\left(\mathrm{k}_{\mathrm{zhs}}\right)$

Table 4.4. Half-Life Values for Hydrolysis of Carbon Tetrachloride in Deionized Water Based on Rate Constants Listed in Table 4.2.

Table 4.5. Rate Constants for Hydrolysis of Carbon Tetrachloride in Hanford Groundwater .......4.5

Table 4.6. Half-Life Values for Hydrolysis of Carbon Tetrachloride in Hanford Site Groundwater Based on Rate Constants Listed in Table 4.5

Table 4.7. Arrhenius Parameters for Hydrolysis of Carbon Tetrachloride in Homogeneous Aqueous Solution (Deionized Water and Groundwater) and Corresponding Half-Lives Estimated for $16^{\circ} \mathrm{C}$

Table 4.8. Conditions for Homogeneous Chloroform Hydrolysis Experiments and the Relative Confidence of the Rate Constants Obtained...

Table 4.9. Rate Constants for Neutral Homogeneous Hydrolysis of Chloroform

Table 4.10. Rate Constants for Base-Catalyzed Homogeneous Hydrolysis of Chloroform

Table 4.11. Conditions for Heterogeneous Carbon Tetrachloride Hydrolysis Experiments and the Relative Confidence of the Rate Constants Obtained.

Table 4.12. Rate Constants for Hydrolysis of Carbon Tetrachloride in Suspensions of Hanford Site Sediment in Hanford Groundwater ....

Table 4.13. Half-Life Values for Hydrolysis of Carbon Tetrachloride in Suspensions of Hanford Site Sediment in Hanford Site Groundwater Based on Rate Constants in Table 4.12 .......4.13

Table 4.14. Rate Constants for Hydrolysis of Carbon Tetrachloride in Suspensions of Minerals in Hanford Groundwater.

Table 4.15. Conditions for Heterogeneous Chloroform Hydrolysis Experiments and the Relative Confidence of the Rate Constants Obtained

Table 4.16. Pseudo-First-Order Rate Constants $\left(\mathrm{k}_{\mathrm{pfo}}\right)$ for Hydrolysis of Chloroform in Suspensions of Hanford Sediment or Specific Minerals in Hanford Groundwater. 



\subsection{Introduction}

Between 1955 and 1973, an estimated 920,000 kg of carbon tetrachloride (CT) were discharged to the soil in the 200 West Area of the Hanford Site as part of the plutonium production process (Oostrom et al. 2007). Of this amount, some CT reached the groundwater more than $70 \mathrm{~m}$ below the ground surface and formed a plume of $10 \mathrm{~km}^{2}$ extent. Remediation of the CT plume is underway using a pump-and-treat approach to reduce concentrations of CT and other contaminants such as chloroform (CF) and radionuclides in the aquifer over a projected 25-year operational period (EPA, Ecology, and DOE-RL 2008). Following the period of pump-and-treat operation, monitored natural attenuation will be the continuing remedy to reach groundwater remediation goals. Multiple mechanisms of natural attenuation can reduce $\mathrm{CT}$ and $\mathrm{CF}$ concentrations over time during pump-and-treat and the subsequent monitored natural attenuation remedy phases.

Of the possible natural-attenuation mechanisms, biodegradation is not likely to contribute significantly (Truex et al. 2001), and mechanisms such as dispersion, dilution, and sorption to Hanford Site sediments have been the focus of previous field and modeling efforts (e.g., Riley et al. 2005). In contrast, abiotic-degradation processes such as hydrolysis and reduction, which are likely to contribute significantly to natural attenuation (Truex et al. 2001), are not well understood or quantified. The work in this project was designed to partly bridge that gap by determining the mechanisms and rates associated with hydrolysis.

Prior to this project, estimates of chlorinated-methane hydrolysis rates were based on studies conducted at high temperatures (typically $70^{\circ} \mathrm{C}-150^{\circ} \mathrm{C}$ ) and extrapolated to ambient conditions using the Arrhenius equation. The use of data extrapolated from higher temperatures to estimate hydrolysis rates at groundwater temperatures injected considerable uncertainty into any attempt to determine the role of abiotic processes in $\mathrm{CT}$ and $\mathrm{CF}$ degradation and frustrated the development and design of possible remedies. To resolve this situation, collection of hydrolysis rate data at temperatures at or near actual groundwater temperatures was needed. Because the hydrolysis rates are very slow at low temperatures, adequate resolution of the issue required a lengthy experiment (at least 5 years), extremely accurate sampling and analytical procedures, control of temperature and microbial populations, adequate headspace in the vials to minimize pressure effects, and a large number of replicates. Not surprisingly, the combination of these requirements inhibited the collection of these data at ambient temperatures heretofore.

In addition to the uncertainty associated with temperature, the possibility of heterogeneous catalytic effects on hydrolysis rates exists. In 1994, Jeffers et al. reported on a search for heterogeneous catalysis in the hydrolysis of trichloroethene, tetrachloroethene, and 1,1,1-trichloroethane. In experiments executed at $102^{\circ} \mathrm{C}$ or $106^{\circ} \mathrm{C}$, no additional hydrolysis reactivity was observed with aqueous solutions containing finely divided dispersions of eleven different minerals (Jeffers et al. 1994). However, any catalytic process would be characterized by a lower activation energy, implying that Arrhenius curves for homogeneous and heterogeneous reactions could cross at some relatively low temperature, and in any case, a heterogeneous reaction path would become increasingly important as temperature decreased due to the increased probability of sorption.

This study was initiated to decrease the uncertainties in abiotic degradation rates of $\mathrm{CT}$ and $\mathrm{CF}$ associated with temperature and possible heterogeneous effects. Homogeneous and heterogeneous 
hydrolysis rates were quantified for CT and CF to improve estimates of the contribution of hydrolysis to natural attenuation of the contaminant plumes under the subsurface conditions at the Hanford Site (e.g., temperature and sediment mineralogy). Experiments were conducted for a temperature range of $20-93$ ${ }^{\circ} \mathrm{C}$ for periods as long as 6 years, and the Arrhenius equation was used to estimate activation energies and calculate half-lives for typical Hanford groundwater conditions (temperature of $16^{\circ} \mathrm{C}$ and $\mathrm{pH}$ of 7.75). After two years of data collection, preliminary evidence for heterogeneous effects was reported for hydrolysis of CT (Amonette et al. 2008), and for the effects of different mineral types on CF hydrolysis rates (Amonette et al. 2009). As documented in the subsequent reports (Amonette et al. 2010a, 2010b) and confirmed in the present report, with longer experimentation, the evidence for heterogeneous effects on CT hydrolysis faded, whereas that for the effect of one type of mineral on CF hydrolysis strengthened. This mineral type, smectite, has a significant $\mathrm{pH}$-buffering capacity and its effect therefore probably stems from the fact that CF hydrolyzes by both neutral and base-catalyzed mechanisms.

The overall goals of this project were to:

1. Determine the homogeneous rates of hydrolysis for CT and CF (including neutral and base-catalyzed rates) in deionized water and Hanford Site groundwater at temperatures from $20^{\circ} \mathrm{C}$ to $70^{\circ} \mathrm{C}$.

2. Determine the Arrhenius parameters (i.e., activation energy and prefactor) for hydrolysis of CT and $\mathrm{CF}$ in aqueous systems using the hydrolysis rate data collected at temperatures of $20^{\circ} \mathrm{C}$ to $70^{\circ} \mathrm{C}$ together with previously published data, thus allowing highly accurate interpolated estimates of hydrolysis rate at any temperature in the $20-150{ }^{\circ} \mathrm{C}$ range and reasonable extrapolation to groundwater temperatures.

3. Determine the impact and mechanisms of fine-grained Hanford Site sediment in Hanford groundwater and of representative Hanford mineral surfaces on the hydrolysis of CT and CF at nearambient temperatures.

Analysis of experiment data required use of Henry's Law liquid-vapor partitioning coefficients. Because of the sensitivity of the analyses to the value of these coefficients, experiments were conducted to measure partitioning coefficients under the conditions used in the hydrolysis rate experiments. It is important to note that the determined liquid-vapor partition coefficients for CT under the temperatures and pressures encountered in the sealed vessels used for hydrolysis experiments differ significantly from extrapolations of published Henry's Law coefficients. 


\subsection{Experimental Approach}

Experiments were conducted in the Environmental Molecular Sciences Laboratory at Pacific Northwest National Laboratory (PNNL) and at the State University of New York at Cortland (SUNYCortland). As described below, the experiments at PNNL used ampules with a headspace-to-liquid ratio of about 1:2.2. The SUNY-Cortland experiments used minimal-headspace ampules (headspace-to-liquid ratio of about 1:50) and a zero-headspace reactor (ZHR). The SUNY-Cortland work also included direct determinations of liquid-vapor partition coefficients for CT and CF using a specially built reactor.

At PNNL, the overall experimental design involved collection of data at four to six temperatures covering the range of $20^{\circ} \mathrm{C}-70^{\circ} \mathrm{C}$. Samples were incubated under one of three environments (sterile deionized water, sterile filtered Hanford 200-Area groundwater, sterile Hanford 200-Area sediment or pure-phase minerals in 200-Area groundwater), at one of two initial concentrations ( $40 \mathrm{ppm}$ or $400 \mathrm{ppm}$ ), for periods of up to 6 years. We conducted five replicate analyses for each treatment combination at each of ten times during the experiment. Reaction progress was followed by measurement (using ion chromatography) of the chloride released. Two additional replicates were prepared as controls for potential analysis by gas chromatography in the event that non-hydrolytic degradation pathways were suspected. In addition, another 14 ampules were prepared for each temperature/environment combination to ascertain initial and maximum potential concentrations of chloride. Thus, the number of ampules for a temperature/environment combination was 84 .

Selected subsets of these experimental conditions were identified for corroborative experiments conducted at SUNY-Cortland. This work included development of novel ZHRs and focused on determination of hydrolysis rates in homogeneous systems (primarily deionized water).

Over the course of the project, 99 temperature/environment combinations (a total of more than 8300 ampules) were started at PNNL and an additional 34 experimental combinations were sampled at SUNYCortland. Sections $2.1-2.3$ provide details of the laboratory procedures used and calculations followed, together with analyses of the groundwater, sediment, and representative minerals.

\subsection{Groundwater, Sediment, and Minerals}

Uncontaminated Hanford groundwater was obtained from Well 699-49-100C located near the Yakima barricade west and upgradient of the 200-West Area at the Hanford Site. The sample \# B1JX90 (SAF\# X06-043) was collected on 12 July 2006. Water from this well has been used by the Hanford groundwater monitoring project for background values for a number of years. Although not measured specifically for the samples in this project (aside from chloride) the composition of the water from this well is summarized from Hanford Environmental Information System (HEIS) data in Table 2.1. 
Table 2.1. Typical Composition and Chemical Properties of Hanford Groundwater from Well 699-49-100C

\begin{tabular}{cc}
\hline Constituent/Property & $\begin{array}{c}\text { Value } \\
\text { otherwise indicated })\end{array}$ \\
\hline $\mathrm{SO}_{4}^{2-}$ & 75000 \\
$\mathrm{NO}_{3}^{-}$ & 13000 \\
$\mathrm{Cl}^{-}$ & 19000 \\
$\mathrm{~F}^{-}$ & 300 \\
$\mathrm{Ca}^{2+}$ & 60000 \\
$\mathrm{Mg}^{2+}$ & 21000 \\
$\mathrm{Na}^{+}$ & 25000 \\
$\mathrm{~K}^{+}$ & 7500 \\
Fe (valence unspecified) & 30 \\
Alkalinity & 175000 \\
Total Organic Carbon & 1000 \\
Electrical Conductivity $\left(\mu \mathrm{S} \mathrm{cm}{ }^{-1}\right)$ & 570 \\
pH (log units) & 7.75 \\
\hline
\end{tabular}

Uncontaminated Hanford sediment was a silt loam (22\% clay, $78 \%$ silt) obtained from Borehole 299-W15-46 (SAF\#F03-018, SAMP\# B19NK8). The sample was collected on 4 January 2005 at 216-Z-9/C3426 from a depth of $421.5 \mathrm{ft}$ to $423.5 \mathrm{ft}$ using a split-spoon liner. The mineralogy of the Hanford sediment was determined by $x$-ray diffraction of the whole sediment and of the clay $(<2-\mu \mathrm{m}$ particle size) fraction according to the procedures of Amonette. ${ }^{1}$

The results of the textural and mineralogical analysis of the Hanford sediment are summarized in Table 2.2. Based on the particle-size analysis, the sediment can be classified as a silt loam. Quartz was the most abundant mineral, followed by smectite and plagioclase feldspar ( $60 \%$ anorthite $/ 40 \%$ albite). Other layer silicates, such as mica/illite and kaolin/serpentine were present in measurable quantities.

Based on this analysis and the ready availability of mineralogically pure samples, we selected montmorillonite (a type of smectite), kaolinite, albite, and muscovite (a type of mica) as the four minerals for testing of heterogeneous effects on hydrolysis (Table 2.3). Quartz, although the most abundant mineral, was not selected because of its ubiquity in soils and sediments. Any heterogeneous effect seen in our tests with bulk sediment that exceeded that for the minerals selected for testing could be attributed to quartz or to a highly reactive mineral that could not be detected by our method. One such class of

\footnotetext{
${ }^{1}$ Amonette JE. 1994a. Soil texture determinations and preparation of samples for mineralogical analysis by x-ray diffraction (XRD). PNL Procedure JEA-2, Revision 0, Pacific Northwest National Laboratory, Richland, Washington.

Amonette JE. 1994b. Mineralogical analysis of soil samples by x-ray diffraction (XRD). PNL Procedure JEA-3, Revision 0, Pacific Northwest National Laboratory, Richland, Washington.
} 
Table 2.2. Texture and Mineralogy of Hanford Sediment

\begin{tabular}{lc} 
& \multicolumn{2}{c}{ Weight Percent } \\
\hline & Particle Size Class \\
\hline Sand $(>53 \mu \mathrm{m})$ & 0 \\
\hline Silt $(2-53 \mu \mathrm{m})$ & 78 \\
Clay $(<2 \mu \mathrm{m})$ & 22 \\
\hline & Bulk Mineralogy \\
\hline Quartz & 49 \\
Plagioclase $(60: 40$ & 10 \\
Anorthite:Albite $)$ & \\
Potassium feldspar & 1 \\
Smectite & 30 \\
Mica/illite & 6 \\
Kaolin/serpentine & 5 \\
\hline
\end{tabular}

Table 2.3. Minerals Used in Heterogeneous Experiments and Their Source Locales

\begin{tabular}{ll}
\hline \multicolumn{1}{c}{ Mineral } & \multicolumn{1}{c}{ Source Locale } \\
\hline $\begin{array}{l}\text { Montmorillonite } \\
(<2 \mu \text { m fraction) }\end{array}$ & $\begin{array}{l}\text { Newcastle Formation, Crook County, Wyoming (SWy-2, Source Clay of The Clay Minerals } \\
\text { Society) }\end{array}$ \\
Kaolinite & Bath, South Carolina (Peerless \#2) \\
Albite & $\begin{array}{l}\text { Kona, South Carolina (SRM 99a, Soda Feldspar, National Institute of Standards and } \\
\text { Technology) }\end{array}$ \\
Muscovite & Stoneham, Maine (ground to silt size) \\
\hline
\end{tabular}

reactive minerals would be the iron and manganese oxides. If much higher reactivity was seen with the bulk sediment than with our mineralogically pure samples, further work could involve these more reactive but less abundant minerals. We were careful to select minerals that had no Fe(II) in their structures and ensured this by oxidatively sterilizing them with $10 \%$ hydrogen peroxide to convert labile Fe(II) to Fe(III).

In the heterogeneous experiments with minerals, we used $28 \mathrm{mg}$ montmorillonite in each ampule and $20 \mathrm{mg}$ of the other three minerals. In the initial experiment, the montmorillonite was sterilized by adding the appropriate amount of clay to each ampule as $1 \mathrm{~mL}$ of aqueous slurry, incubating for one week to induce vegetative growth of microorganisms, and then adding $0.5 \mathrm{~mL}$ of $30 \% \mathrm{H}_{2} \mathrm{O}_{2}$. The ampules were wrapped in autoclave paper and oven-dried at $40^{\circ} \mathrm{C}$. Once dry, the clay was re-wetted with $0.75 \mathrm{~mL} \mathrm{H}_{2} \mathrm{O}$ to displace any residual $\mathrm{H}_{2} \mathrm{O}_{2}$ and dried again. The clay was re-wetted one more time, dried, and then stored in the autoclave paper until use. The other three minerals were sterilized in batch mode before they were weighed into the ampules using a similar sequence of wetting, oxidation with $\mathrm{H}_{2} \mathrm{O}_{2}$, and drying. 


\subsection{Hydrolysis Rates}

\subsubsection{PNNL Methods}

At PNNL, a stock solution saturated with CT was prepared by adding $8 \mathrm{~mL}$ of high-performance liquid chromatography-grade CT ( $>99.9 \%$ pure, Sigma-Aldrich, 270652$)$ to $1 \mathrm{~L}$ deionized $\mathrm{H}_{2} \mathrm{O}$ in a borosilicate glass bottle containing 10 glass beads. The mixture was shaken continuously on an orbital shaker at $150 \mathrm{rpm}$ for several weeks before being used. The nominal concentration of CT in this stock solution was about $800 \mathrm{mg} \mathrm{L}^{-1}$.

For CF, 0.5 L of pesticide residue analysis-grade CF ( $>99.9 \%$ pure, Sigma-Aldrich, 324019) was purified to remove the amylene stabilizer by contact with $80 \mathrm{~g}$ of $13 \mathrm{X}$ molecular sieve followed by vacuum degassing. This purified reagent $\mathrm{CF}$ was then used to prepare a saturated stock solution by adding at least $100 \mathrm{~mL}$ to about $2 \mathrm{~L}$ of deionized $\mathrm{H}_{2} \mathrm{O}$ or Hanford groundwater in a volumetric flask that was capped and allowed to shake as for the CT solution for at least two weeks at room temperature. The nominal concentration of $\mathrm{CF}$ in the saturated stock solution was $8000 \mathrm{mg} \mathrm{L}^{-1}$.

Starting solutions for hydrolysis determinations were prepared in 1.2-L polytetrafluoroethylene gas sampling bags (Alltech 41004, Deerfield, Illinois). The appropriate masses of CT/CF stock solution and deionized water were filter-sterilized (Anotop 25, Whatman) and added to the sampling bag using a sterile glass syringe driven by a syringe pump. For $\mathrm{CF}$ experiments, $\mathrm{pH}$ control was provided by addition of $\mathrm{H}_{2} \mathrm{SO}_{4}$ (pH 3.3) or a 0.1-M sodium phosphate buffer ( $\mathrm{pH} 8.05$ or 12.11). The concentrations of hydroxyl ion in these solutions were calculated from compositional data and $\mathrm{pH}$ determinations using Visual MINTEQ version 3.0 (Gustaffson, 2012). Also, $10 \mu \mathrm{L}$ of neat perchloroethene (PCE), which has an hydrolysis half-life of $10^{9}$ years (Jeffers et al. 1989), was added as an internal standard during gas chromatographic (GC) analyses. Some water was added and headspace in the bag eliminated before the $\mathrm{CT} / \mathrm{CF}$ stock solution, $\mathrm{pH}$ reagent, and PCE were added. A typical final volume in the bag was $800 \mathrm{~mL}$, and initial CT/CF concentrations were nominally 40 or $400 \mathrm{mg} \mathrm{L}^{-1}$. After addition, the contents of the bag were mixed by gently squeezing the bag. Then the outlet on the bag was attached to the inlet of a dispenser designed for organic liquids (Dispensette Organic, BrandTech Scientific, Essex, Connecticut), and the contents were dispensed through a large-bore stainless-steel needle into ampules for immediate sealing.

The hydrolysis experiments were conducted in 1-mL (nominal volume) glass ampules (Figure 2.1 left, Wheaton 176772, Millville, New Jersey). These ampules typically have an internal volume of 2.4 $\mathrm{mL}$ when sealed. We added $1.6 \mathrm{~mL}$ of aqueous sample to the ampule, leaving $0.8 \mathrm{~mL}$ as headspace. The ampules were sealed within $15 \mathrm{~s}$ of sample addition using an automatic ampule sealer (Figure 2.1, right; Ampulmatic Model 290 001, Bioscience, Inc., Bethlehem, Pennsylvania).

For each incubation temperature, 84 ampules were prepared. Seventy of these were incubated at the desired temperature and sampled in batches of seven after various periods to determine hydrolysis rate. The first batch was sampled immediately after ampule sealing and defined the starting conditions for the experiment (e.g., some hydrolysis can occur during the ampule-sealing process due to the high temperatures involved). The remaining 14 ampules were controls. Seven were incubated at $100^{\circ} \mathrm{C}$ until hydrolysis was complete and then analyzed to determine the actual starting concentration of CT/CF in the 

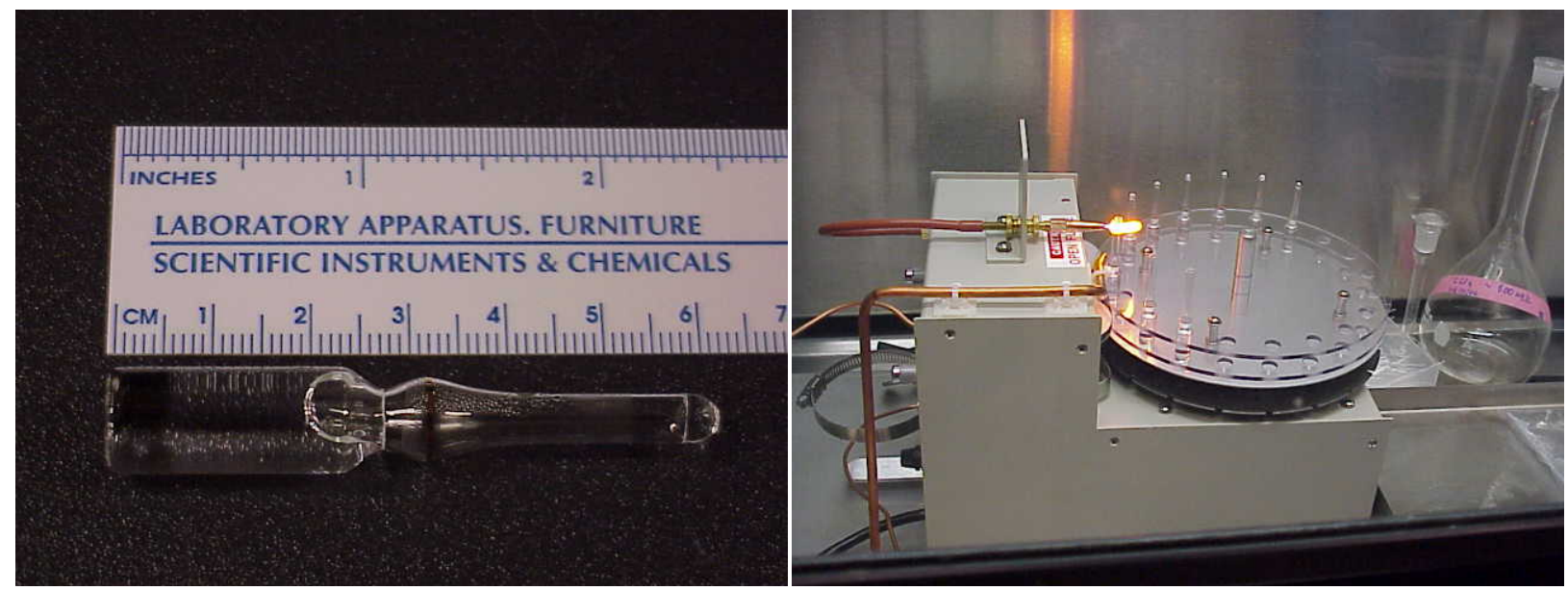

Figure 2.1. Ampule (left) and Automatic Ampule Sealer (right) Used for PNNL Hydrolysis Experiments.

ampules. The other seven were stored at $4{ }^{\circ} \mathrm{C}$ where hydrolysis rates are negligible (except for $\mathrm{CF}$ at $\mathrm{pH}$ 12, which hydrolyzes quite readily). These seven served as reference points for the initial conditions in case any questions arose during the experiment.

During the ampule-preparation process, 8 of the 84 ampules were selected at regularly spaced intervals to provide data for the estimation of headspace volume (this was done by weighing the empty ampule and the same ampule after filling and sealing). After incubation, but before the ampules were opened during the sampling process, the ampules were reweighed to verify no leakage, and their headspace was determined by a differential density approach. A syringe large enough to contain the ampule was filled with water of known density and weighed. Some of the water was then displaced by the sealed ampule (the total volume within the syringe remained the same with no air bubbles), and the syringe with ampule was re-weighed. From these data and the physical properties of the solutions and glass, the headspace within the ampule $\left(\mathrm{V}_{\mathrm{v}}\right)$ was calculated by

$$
\mathrm{V}_{\mathrm{v}}=\left(\mathrm{m}_{\text {tot }}^{\mathrm{A}}-\mathrm{m}_{\text {tot }}^{\mathrm{B}}+\mathrm{m}_{\mathrm{Amp}+\mathrm{CT} / \mathrm{CF}}\right) / \rho_{\mathrm{H} 2 \mathrm{O}}-\left(\mathrm{m}_{\mathrm{Amp}} / \rho_{\mathrm{Amp}}\right)-\left(\mathrm{m}_{\mathrm{CT} / \mathrm{CFSoln}} / \rho_{\mathrm{CT} / \mathrm{CFsoln}}\right)
$$

where $\mathrm{m}_{\text {tot }}^{\mathrm{A}}=$ mass of syringe filled with $\mathrm{H}_{2} \mathrm{O}, \mathrm{m}^{\mathrm{B}}$ tot $=$ mass of syringe filled with sealed ampule and $\mathrm{H}_{2} \mathrm{O}$, $\mathrm{m}_{\mathrm{Amp}+\mathrm{CT} / \mathrm{CF}}=$ mass of filled ampule, $\rho_{\mathrm{H} 2 \mathrm{O}}=$ density of water, $\mathrm{m}_{\mathrm{Amp}}=$ mass of empty ampule, $\rho_{\mathrm{Amp}}=$ density of glass in ampule, $\mathrm{m}_{\mathrm{CT} / \mathrm{CFS} \text { oln }}=$ mass of solution in ampule, and $\rho_{\mathrm{CT} / \mathrm{CFs} \text { soln }}=$ density of solution in ampule.

The 70 ampules for hydrolysis measurement were arranged in labeled metal racks (Figure 2.2, left) and incubated at the desired temperature using an air-flow incubator (Figure 2.2, right; Incumax IC 150 or IC 150R, Amerex Instruments, Lafayette, California). Temperature inside each incubator was continuously measured by two thermocouples located near the top and bottom of the incubator volume and recorded on a datalogger (CR3000, Campbell Scientific, Logan, Utah). Thermocouples were calibrated initially using a NIST-certified platinum-resistance thermometer (Hart Scientific 1502A, American Forks, Utah).

After appropriate periods whose length depended on the expected hydrolysis rate and the sensitivity of our analytical determinations, seven samples were removed from the incubator, and the hydrolysis reaction was quenched. For $\mathrm{CT}$ and all $\mathrm{CF}$ samples except those at $\mathrm{pH} 12$, quenching was achieved by storage in $4^{\circ} \mathrm{C}$ refrigerator. When convenient for analysis (or immediately for $\mathrm{pH}-12 \mathrm{CF}$ samples), five 
samples from each time period were opened and their contents transferred to pre-cleaned glass ion chromatography (IC) vials. The pre-cleaning procedure to remove traces of chloride from the IC vials involved soaking them in deionized $\mathrm{H}_{2} \mathrm{O}$ for several days, with two changes of $\mathrm{H}_{2} \mathrm{O}$ during the first day and one change on each subsequent day. The transferred samples remained at $4{ }^{\circ} \mathrm{C}$ until IC analysis was completed. For all $\mathrm{CF}$ samples, $0.5 \mathrm{~mL}$ of hexane was added to the vial to extract $\mathrm{CF}$ from the aqueous solution. This was necessary to prevent damage to the IC column. If the expected levels of the analyte (chloride ion) were greater than $100 \mathrm{mg} \mathrm{L}^{-1}$, then $5 \mathrm{x}$ dilutions with deionized $\mathrm{H}_{2} \mathrm{O}$ were made from these vials prior to analysis. Otherwise, the vials were analyzed without dilution. Chloride concentrations were determined by IC (Dionex DX-500, AS11-HC column, suppressed conductivity detection). The remaining two samples from each time period were reserved for GC analysis to verify that only hydrolysis reactions occurred (e.g., reduction of CT would yield some chloroform as a product, which is easily detected by GC methods).
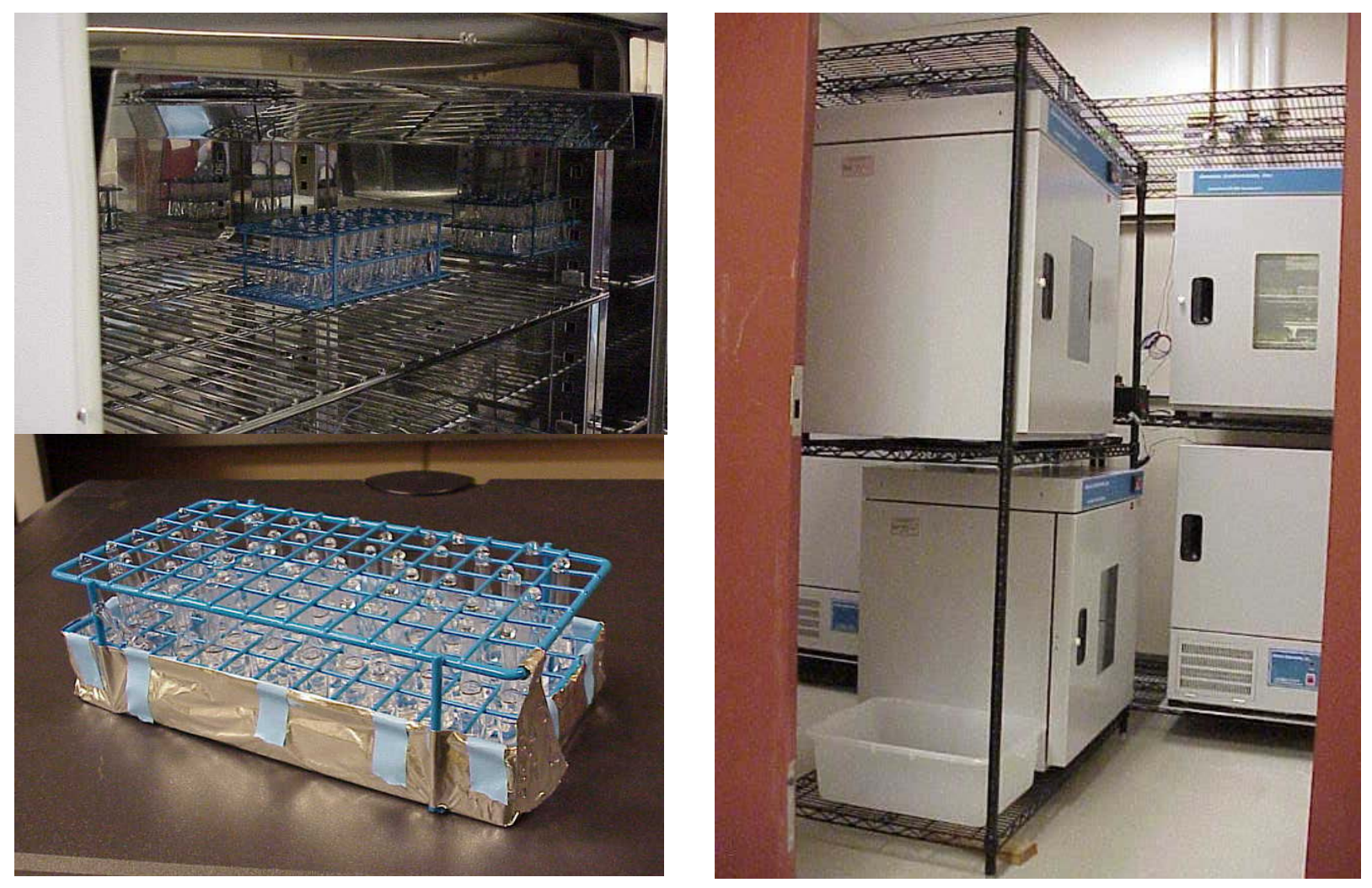

Figure 2.2. Set of Ampules in Rack (top left) Ready for Insertion into Incubator (bottom left) and Incubator Array Used in PNNL Experiments (right). 


\subsubsection{SUNY-Cortland Methods}

At SUNY-Cortland, the same general approach was used as at PNNL (i.e., hydrolysis in sealed glass container at temperatures in the $20^{\circ}-70^{\circ} \mathrm{C}$ range). Differences were found, however, in the type of container, the headspace-to-liquid ratio, and in the type of incubator. These measurements utilized two water baths constructed for the project, controlled with mercury sensors and electronic relays; they were easily adjusted to desired temperatures and were stable within $0.1^{\circ} \mathrm{C}$ for intervals as long as a month (the longest duration of the actual measurements). Temperatures were measured with mercury thermometers reading to $0.1^{\circ} \mathrm{C}$, and the calibration was checked with ice/deionized water.

Early experiments were conducted using sealed bulbs made from borosilicate glass tubing. The bulbs were drawn from 8-mm outside-diameter tubing and typically had a volume of about $1 \mathrm{~mL}$ with a void volume of $0.04-0.1 \mathrm{~mL}$ at $20^{\circ} \mathrm{C}$. At high temperature, $70^{\circ} \mathrm{C}$, the void volume was reduced to $0.02-0.08 \mathrm{~mL}$ (value determined by both calculation and measurement). A problem that became apparent early in the work was the appearance of measurable $\mathrm{Cl}^{-}$in $\mathrm{t}=0 \mathrm{bulbs}$, due to inadvertent heating of the solution during the sealing process. Re-design of the bulbs reduced this problem but failed to eliminate it. A second problem observed in an early bulb experiment at $60^{\circ} \mathrm{C}$ was the clear evidence of microbial activity. This problem was solved by treating all glassware and other implements that would touch the solution by heating at $120^{\circ} \mathrm{C}$ overnight and wearing surgical gloves for bulb filling. A third problem was associated with determination of the appropriate correction to the observed rate constant to account for partitioning of CT between liquid and headspace. The variable headspace in these bulbs and the consequential need to measure headspace on each and every bulb made corrections for CT partitioning tedious at best and added considerable uncertainty to the data, particularly at the higher temperatures.

To avoid the problems with premature hydrolysis and uncertain headspace, a zero-headspace reactor (ZHR) was designed, fabricated, and used with significant success in these studies. The body of the ZHR (Figure 2.3, top) was a 10-cm length of 20-mm Pyrex tubing with a 10-cm length of 2-mm insidediameter Pyrex capillary at one end and a $25-\mathrm{cm}$ length of 8-mm outside-diameter Pyrex tubing at the other end. The capillary was flared at the end to fit inside a 0.25 -in.-Swagelok fitting and afforded a glass- to 10 -mm-GC septum seal. The 8 -mm tubing was bent in a $\mathrm{U}$ and terminated in a $2-\mathrm{mm}$ Teflon stopcock with a $2-\mathrm{cm}$ by $10-\mathrm{mm}$ Pyrex reservoir at the top, which extended slightly beyond the capillary end. The reactor was filled using a 50-mL glass syringe with a long wide-bore needle until the solution just spilled out past the loosened Swagelok nut, which was then secured. The ZHR was placed into a water thermostat bath with only the ends above water, and the stopcock remained open until the solution was temperature-equilibrated. Samples were drawn into a $1-\mathrm{mL}$ glass syringe fitted with a $15-\mathrm{cm}$ 17-gauge needle that extended to the middle of the reactor body. The stopcock was opened for the sampling process, and the fresh reaction mix was placed in the reservoir above the stopcock. Typically, $0.2-0.3 \mathrm{~mL}$ of solution were withdrawn for analysis. Thus, a run totaling 10 samplings drained far less solution than was contained in the 8-mm feed tube, while the very narrow-gauge sampling needle caused little mixing in the capillary sampling arm.

The ZHR and all associated glassware, syringes, and needles were heat-sterilized before use. The deionized water was boiled and sparged with a flow of He to remove dissolved air. This prevented the formation of air bubbles inside the reactor to which reactant could partition during a run and is an important precaution to take at all temperatures above $40^{\circ} \mathrm{C}$. 


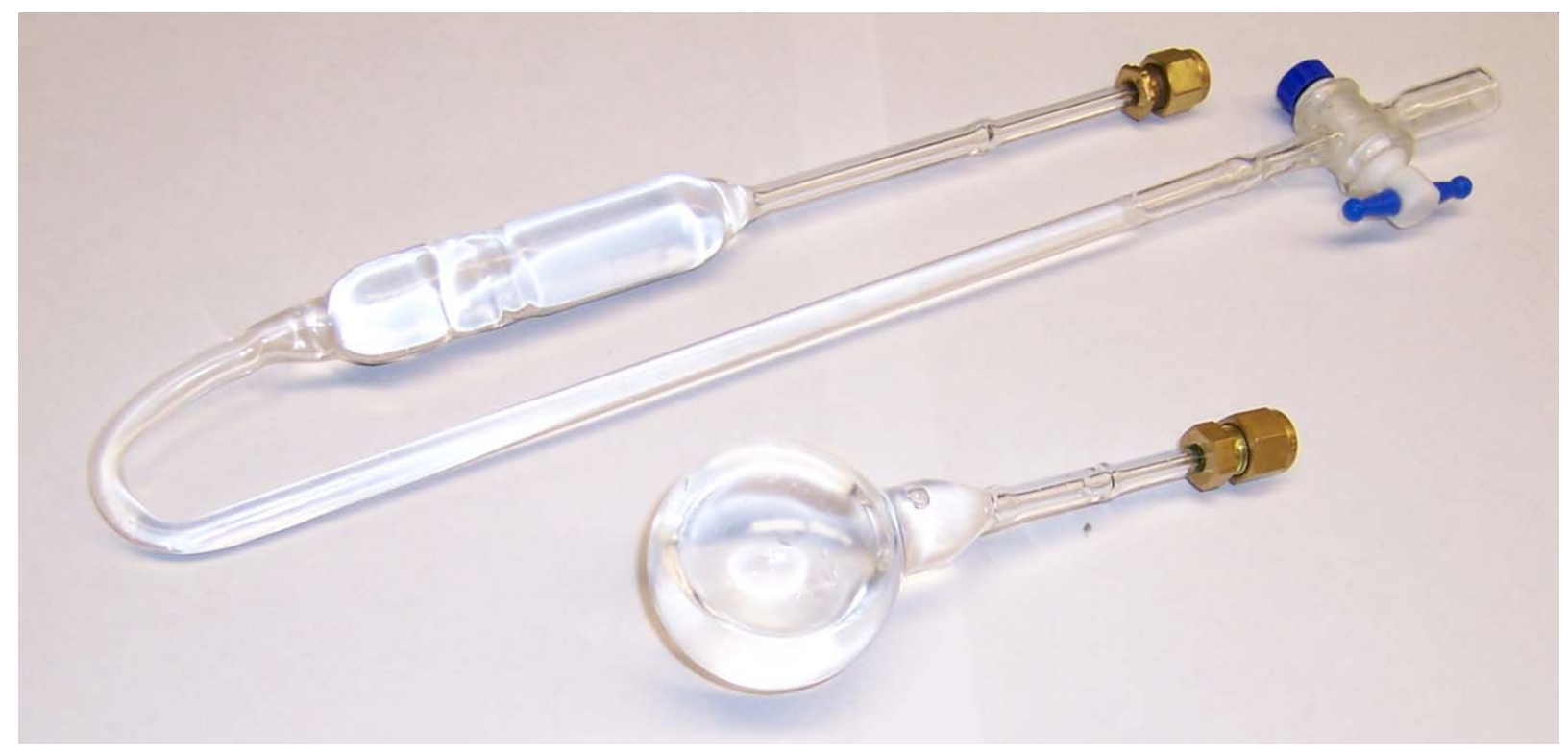

Figure 2.3. Zero-Headspace Reactor (top) and Apparatus for Determination of Liquid-Vapor Partition Coefficients (bottom) Fabricated and Used for Hydrolysis Experiments at SUNY-Cortland.

An essential quantity in calculating the rate constant is the initial concentration of reactant. For experiments in deionized water, this value can be measured by complete hydrolysis of the reactor solution at the end of a run, measuring the total chloride ion liberated. Initially, with CT, about $1 \mathrm{~mL}$ of solution was withdrawn from the reactor, injected into a 1.2-mL bulb drawn from $8-\mathrm{mm}$ Pyrex tubing. The bulb was then quickly flame-sealed and placed in a $130^{\circ} \mathrm{C}$ oven for about 30 hours. CT has a half-life of about 2 hours at $130^{\circ} \mathrm{C}$, so hydrolysis should have been complete. The bulb was opened, and the solution quantitatively diluted to a range appropriate for IC analysis. A significant improvement was to do the dilution prior to hydrolysis by drawing 7-cm-long bulbs from 12-mm Pyrex tubing, adding a weighed amount of deionized water, then injecting about $0.3-0.4 \mathrm{~mL}$ solution with the sampling syringe, carefully keeping the needle tip near the bottom of the bulb, then quickly flame-sealing and re-weighing to determine the dilution factor. The revised process allowed very little opportunity for reactant to diffuse out of solution before the bulb was sealed and resulted in very close agreement on concentration with duplicate samples.

The SUNY-Cortland experiments with CF utilized 0.01 molal $\mathrm{NaOH}$ solutions. Concentrations of CF were about $50-150 \mathrm{mg} \mathrm{L}^{-1}$, or $0.00126-0.00378$ molal, low enough that the base concentration changed little during the experiment $(<10 \%$ completion) and pseudo-first-order kinetics could be assumed. Advantages of the dilute-base approach are that the $\mathrm{OH}^{-}$concentration could be measured directly and there was no temperature dependence on any acid/base equilibrium constant, as would be the case with any buffer solution. Another advantage was that kinetics properly uses concentration rather than activity, which is the quantity reported by a $\mathrm{pH}$ meter. The concentration was measured directly and accurately by titration of a primary standard, potassium hydrogen phthalate in this case. Finally, at this base concentration, $\mathrm{CF}$ hydrolyzed to completion in two days at $70^{\circ} \mathrm{C}$, so to determine final concentration the entire ZHR could be placed in an oven, stopcock open until the temperature had equilibrated, affording the entire reactor contents for final analysis. 


\subsection{Liquid-Vapor Partition Coefficients}

At SUNY-Cortland, an apparatus was designed and fabricated, and techniques were developed to measure liquid-vapor partition coefficients at the temperatures and conditions of our experiments, as the only available data (Gossett, 1987; Gorgenyi et al., 2002) did not extend beyond $60^{\circ} \mathrm{C}$ and were not necessarily valid for the high concentrations we were using. The technique relied on measurement of solution concentrations of $\mathrm{CT}$ or $\mathrm{CF}$, based on total analysis of $\mathrm{Cl}^{-}$concentration after total hydrolysis.

The apparatus (Figure 2.3, bottom), which consisted of a 50-mL round-bottom Pyrex bulb with the neck replaced by a $5-\mathrm{cm}$ length of 1-mm-inner diameter capillary glass flared at the top and fitted with a 0.25-in. fitting (Swagelok) so that a rubber septum directly sealed to the glass, was similar to the ZHR but without a second fill tube. The bulb could be rinsed, filled, and drained using a syringe. In practice, the bulb was weighed empty, filled using a 50-mL syringe and long wide-bore needle, weighed full, and sampled with a 1-mL syringe and 17-gauge needle, then drained about one-third using the 50-mL syringe, quickly sealed, reweighed, and immersed in the thermostat bath. The bulb was shaken several times over a 15 -30-min interval, then sampled through the septum while still in the bath, to determine an equilibrium solution concentration. During the draining process, some solution was deposited in the capillary to serve as an indicator that no solution or vapor escaped through the septum. The initial and equilibrium samples were then hydrolyzed to completion as with the ZHR experiments. The dimensionless partition coefficient could be simply calculated as

$$
\mathrm{K}_{\mathrm{lv}}=\left[\left(\mathrm{C}_{0}-\mathrm{C}_{\mathrm{f}}\right) / \mathrm{C}_{\mathrm{f}}\right]\left(\mathrm{V}_{\mathrm{l}} / \mathrm{V}_{\mathrm{v}}\right)
$$

where $\mathrm{C}_{0}$ and $\mathrm{C}_{\mathrm{f}}$ are the initial and equilibrium liquid concentrations of $\mathrm{Cl}^{-}$in ppm, and $\mathrm{V}_{1}$ and $\mathrm{V}_{\mathrm{v}}$ are the equilibrium liquid and vapor volumes.

At PNNL, we developed an infrared spectroscopic method to measure the concentrations in the vapor phase (both CT and CF give strong absorptions in the mid-infrared part of the spectrum). We purchased an ultra-low-volume 0.5 -m path length gas cell (Figure 2.4) with a nominal sample volume of $25 \mathrm{ml}$. This cell required a minimum of about $35 \mathrm{~mL}$ of gas to totally flush the cell with a new sample.

In a typical experiment, which was adapted from that of McAuliffe (1971) as described in Schwarzenbach et al. (1993, p. 118-119), we equilibrated $50 \mathrm{~mL}$ of liquid (containing either CT or CF) in a $100-\mathrm{mL}$ gas syringe with $50 \mathrm{~mL}$ of headspace at a fixed temperature. The exact volumes of the liquid and headspace were determined gravimetrically. Temperature was maintained by an incubating shaker cabinet, and the syringe was fixed in a special holder so that it could be agitated at $200 \mathrm{rpm}$ to induce adequate mixing between the liquid and the vapor in the syringe. Incubation period for each equilibration was ten minutes, as determined by preliminary experiments. At the end of the equilibration period, the headspace in the syringe was transferred to another gas syringe, which was securely capped and allowed to cool to room temperature. Fresh headspace was then added to the first syringe and a new equilibration period started. Once the sample in the second syringe had reached ambient temperature the gas was injected into the gas cell in the spectrometer. A spectrum was obtained in about 5 minutes.

An experiment consisted of several (at least 4) successive equilibrations, with the concentration of CT or CF in the vapor decreasing each time (Figure 2.5). A plot of the log of the concentration versus equilibration number yielded a straight line (Figure 2.6), the slope of which was used, together with the volumes of liquid and gas in the syringe, to calculate the partition coefficient $\left(\mathrm{K}_{\mathrm{lv}}\right)$ by 


$$
\mathrm{K}_{\mathrm{lv}}=\left(10^{-\mathrm{n}}-1\right)\left(\mathrm{V}_{1} / \mathrm{V}_{\mathrm{v}}\right)
$$

where $\mathrm{n}$ is the slope, $\mathrm{V}_{1}$ the volume of liquid and $\mathrm{V}_{\mathrm{v}}$ the headspace volume. For each experiment, we estimated concentration by the height of the absorption peak and by the area of the absorption peak. The two values thus obtained were then averaged, along with values from identical experiments, to obtain an estimate of the partition coefficient.

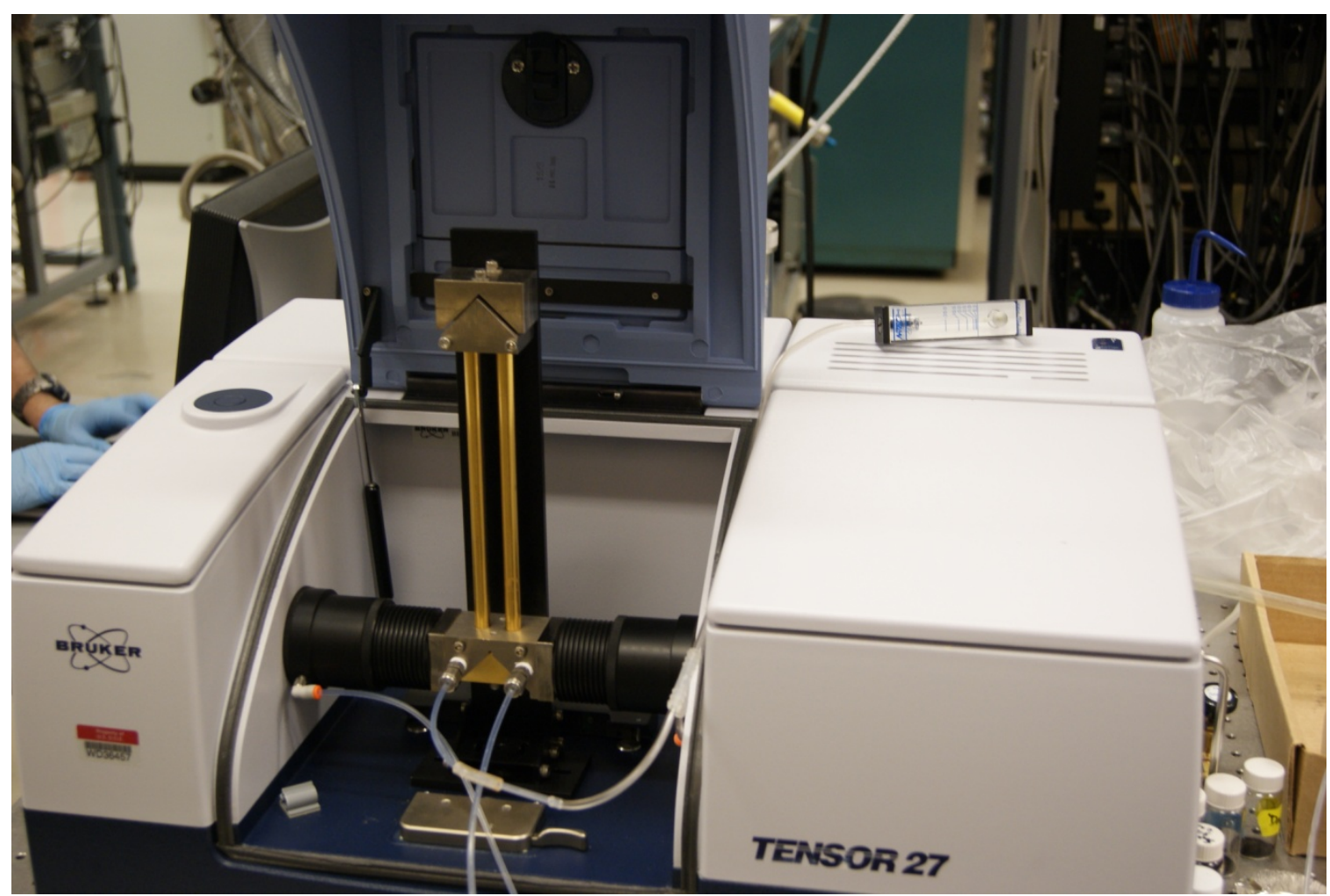

Figure 2.4. Infrared Gas Cell and Spectrometer Used in the Liquid-Vapor Partition Coefficient Determinations at PNNL. 


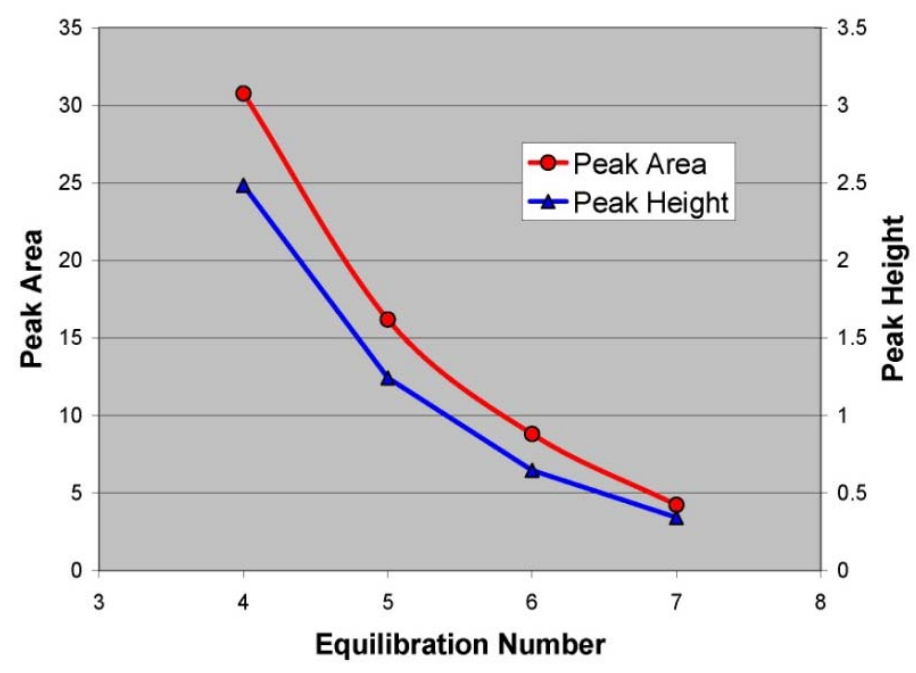

Figure 2.5. Plot of Typical Absorbance Data for Successive Equilibrations of CT in the Partition Coefficient Determination.

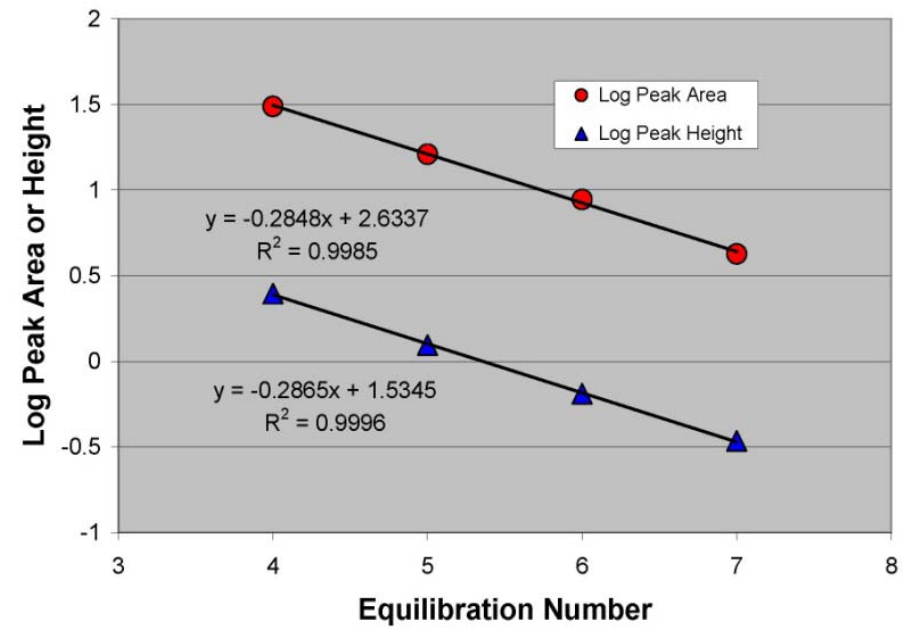

Figure 2.6. Linear Relation Between Log of Absorbance and Equilibration Number.

\subsection{Calculations}

\subsubsection{Carbon Tetrachloride}

The hydrolysis of CT follows the overall reaction

$$
\mathrm{CCl}_{4}+2 \mathrm{H}_{2} \mathrm{O} \rightarrow \mathrm{CO}_{2}+4 \mathrm{H}^{+}+4 \mathrm{Cl}^{-}
$$


The rate law for this reaction is

$$
-\mathrm{d}\left[\mathrm{CCl}_{4}\right] / \mathrm{dt}=(1 / 4) \mathrm{d}\left[\mathrm{Cl}^{-}\right] / \mathrm{dt}=\mathrm{k}\left[\mathrm{CCl}_{4}\right]
$$

which, upon integration, yields

$$
\left[\mathrm{Cl}^{-}\right]_{\mathrm{t}}=4\left[\mathrm{CCl}_{4}\right]_{0}[1-\exp (-\mathrm{kt})]
$$

Rearranging and taking the natural log of both sides yields

$$
\ln \left\{1-\left[\mathrm{Cl}^{-}\right]_{\mathrm{t}} /\left(4\left[\mathrm{CCl}_{4}\right]_{0}\right\}=-\mathrm{kt}\right.
$$

A plot of the left side of Equation 2.7 versus time yields a straight line with a slope of $-\mathrm{k}$, the apparent rate constant.

In our work, we determined $\left[\mathrm{CCl}_{4}\right]_{0}$ by the difference between the final $\left[\mathrm{Cl}^{-}\right]$with complete hydrolysis [i.e., data from long-term hydrolysis at $100^{\circ} \mathrm{C}(\mathrm{PNNL})$ or $\left.130^{\circ} \mathrm{C}(\mathrm{SUNY}-\mathrm{Cortland})\right]$ and the initial $\left.\mathrm{Cl}^{-}\right]$ [data from time $=0$ samples]. We then calculated the value of the left side of Equation 2.7 for each time data point in the given experiment. Regression of these values against the corresponding incubation times yielded the slope, from which the apparent rate constant $\left(\mathrm{k}_{\mathrm{app}}\right)$ was obtained by multiplying by -1 . For reaction vessels with headspace, partition equilibrium was assumed and the apparent rate constant was corrected to obtain a rate constant normalized to zero headspace $\left(\mathrm{k}_{\mathrm{zhs}}\right)$ by

$$
\mathrm{k}_{\mathrm{zhs}}=\mathrm{k}_{\mathrm{app}}\left[1+\left(\mathrm{K}_{\mathrm{lv}}\right)\left(\mathrm{V}_{\mathrm{v}} / \mathrm{V}_{\mathrm{l}}\right)\right]
$$

where $\mathrm{K}_{\mathrm{lv}}$ is the dimensionless liquid-vapor-partition coefficient, and $\mathrm{V}_{1}$ and $\mathrm{V}_{\mathrm{v}}$ are the equilibrium liquid and vapor volumes.

\subsubsection{Chloroform}

The hydrolysis of CF follows two parallel pathways. One of these is independent of $\mathrm{pH}$, whereas the other is first order in $\mathrm{OH}^{-}$. The rate of CF hydrolysis, therefore, is the sum of the rates of the two pathways:

$$
-\mathrm{d}\left[\mathrm{CHCl}_{3}\right] / \mathrm{dt}=\left(\mathrm{k}_{\mathrm{N}}+\mathrm{k}_{\mathrm{B}}\left[\mathrm{OH}^{-}\right]\right)\left[\mathrm{CHCl}_{3}\right]
$$

where $\mathrm{k}_{\mathrm{N}}$ is the rate constant for the neutral ( $\mathrm{pH}$-independent) pathway, and $\mathrm{k}_{\mathrm{B}}$ is the rate constant for the base-catalyzed pathway.

The neutral hydrolysis pathway is

$$
\mathrm{CHCl}_{3}+2 \mathrm{H}_{2} \mathrm{O} \rightarrow \mathrm{HCOOH}+3 \mathrm{H}^{+}+3 \mathrm{Cl}^{-}
$$

and the corresponding integrated and rearranged rate law is analogous to that for CT shown in Equations 2.5 through 2.7 :

$$
\ln \left\{1-\left[\mathrm{Cl}^{-}\right]_{\mathrm{t}} /\left(3\left[\mathrm{CHCl}_{3}\right]_{0}\right\}=-\mathrm{k}_{\mathrm{N}} \mathrm{t}\right.
$$


Neutral hydrolysis is the dominant pathway at $\mathrm{pH}<4$, and Equation 2.11 can be used to estimate $\mathrm{CF}$ hydrolysis under those conditions.

At $\mathrm{pH}$ greater than 4, the base-catalyzed hydrolysis pathway becomes important (and is dominant at $\mathrm{pH}>8$ ) due to the strong neutrophilic character of the hydroxyl ion. The overall reaction can be written as

$$
\mathrm{CHCl}_{3}+4 \mathrm{OH}^{-} \rightarrow \mathrm{HCOO}^{-}+2 \mathrm{H}_{2} \mathrm{O}+3 \mathrm{Cl}^{-}
$$

The rate law for the base-catalyzed hydrolysis reaction is second-order overall, being first-order in both $\mathrm{CHCl}_{3}$ and $\mathrm{OH}^{-}$:

$$
-\mathrm{d}\left[\mathrm{CHCl}_{3}\right] / \mathrm{dt}=-(1 / 4) \mathrm{d}\left[\mathrm{OH}^{-}\right] / \mathrm{dt}=(1 / 3) \mathrm{d}\left[\mathrm{Cl}^{-}\right] / \mathrm{dt}=\mathrm{k}_{\mathrm{B}}\left[\mathrm{CHCl}_{3}\right]\left[\mathrm{OH}^{-}\right]
$$

When the concentrations of $\mathrm{CHCl}_{3}$ and $\mathrm{OH}^{-}$differ by a factor of 10 or more, the reactant at higher concentration remains essentially constant during the first stages of the reaction and the reaction becomes pseudo-first-order (PFO). Thus, at $\mathrm{pH} 12$ and higher, where $\mathrm{OH}^{-}$is in excess, the $\mathrm{PFO}$ rate law becomes

$$
-\mathrm{d}\left[\mathrm{CHCl}_{3}\right] / \mathrm{dt}=-(1 / 4) \mathrm{d}\left[\mathrm{OH}^{-}\right] / \mathrm{dt}=(1 / 3) \mathrm{d}\left[\mathrm{Cl}^{-}\right] / \mathrm{dt}=\mathrm{k}_{\mathrm{Bpfo} 1}\left[\mathrm{CHCl}_{3}\right]
$$

where $\mathrm{k}_{\mathrm{Bpfo} 1} /\left[\mathrm{OH}^{-}\right]_{0}=\mathrm{k}_{\mathrm{B}}$. By analogy to Equations 2.6 and 2.7, the rearranged integrated rate law then becomes

$$
\ln \left\{1-\left[\mathrm{Cl}^{-}\right]_{\mathrm{t}} /\left(3\left[\mathrm{CHCl}_{3}\right]_{0}\right)\right\}=-\mathrm{k}_{\mathrm{B}} \mathrm{t}
$$

At $\mathrm{pH} 8$, where $\mathrm{CHCl}_{3}$ is in excess and the base-catalyzed rate is still much faster than the neutral rate, the PFO rate law becomes

$$
-\mathrm{d}\left[\mathrm{CHCl}_{3}\right] / \mathrm{dt}=-(1 / 4) \mathrm{d}\left[\mathrm{OH}^{-}\right] / \mathrm{dt}=(1 / 3) \mathrm{d}\left[\mathrm{Cl}^{-}\right] / \mathrm{dt}=\mathrm{k}_{\mathrm{Bpfo} 2}\left[\mathrm{OH}^{-}\right]
$$

where $\mathrm{k}_{\mathrm{Bpfo} 2} /\left[\mathrm{CHCl}_{3}\right]_{0}=\mathrm{k}_{\mathrm{B}}$, and by analogy to Equations 2.14 and 2.15,

$$
\ln \left\{1-\left[\mathrm{Cl}^{-}\right]_{\mathrm{t}} /\left(3\left[\mathrm{OH}^{-}\right]_{0}\right\}=-\mathrm{k}_{\mathrm{B}} \mathrm{t}\right. \text {. }
$$

At $\mathrm{pH}$ greater than 8 , then either Equation 2.15 or 2.17 can be used to estimate overall $\mathrm{CF}$ hydrolysis given the dominance of $\mathrm{k}_{\mathrm{B}}$. Between $\mathrm{pH} 4$ and $\mathrm{pH} 8$, neither hydrolysis mechanism (i.e., neutral or basecatalyzed) is dominant, and the overall hydrolysis rate for chloroform is best approximated using both rate constants as in Equation 2.9.

\subsubsection{Half-Life}

Half-lives can be calculated when first-order kinetics apply. They can be calculated also for secondorder kinetic systems, if these are converted to PFO and with the caveat that the concentration of the "constant" reactant indeed remains constant for the duration of the reaction. Thus, for CT, and for CF at $\mathrm{pH}$ less than 4 or greater than 8 , the half-life was estimated by

$$
\mathrm{t}_{1 / 2}=(3.168 \mathrm{e}-8) \ln (2) / \mathrm{k}
$$


where the first factor on the right side converts the rate constant from seconds to years, and $\mathrm{k}$ can be $\mathrm{k}_{\mathrm{zhs}}$, $\mathrm{k}_{\mathrm{N}}$, or $\mathrm{k}_{\mathrm{B}}$. For $\mathrm{CF}$ between $\mathrm{pH} 4$ and $\mathrm{pH} 8$, the half-life can be estimated by substituting $\mathrm{k}_{\mathrm{N}}+\mathrm{k}_{\mathrm{B}}\left[\mathrm{OH}^{-}\right]$for $\mathrm{k}$ in Equation 2.18.

\subsubsection{Activation Energy}

Activation energies were calculated from values of $\mathrm{k}$ at several temperatures using the logarithmic form of the Arrhenius expression

$$
\ln (\mathrm{k})=\ln (\mathrm{A})-\left(\mathrm{E}_{\mathrm{a}} / \mathrm{R}\right)(1 / \mathrm{T})
$$

where $\mathrm{k}$ can be $\mathrm{k}_{\mathrm{zhs}}, \mathrm{k}_{\mathrm{N}}$, or $\mathrm{k}_{\mathrm{B}}\left(\mathrm{s}^{-1}\right)$, A is the pre-exponential factor $\left(\mathrm{s}^{-1}\right), \mathrm{E}_{\mathrm{a}}$ is the activation energy $\left(\mathrm{J} \mathrm{mol}^{-1}\right)$, $\mathrm{R}$ is the gas constant $\left(8.314 \mathrm{~J} \mathrm{~mol}^{-1} \mathrm{~K}^{-1}\right)$, and $\mathrm{T}$ is the reaction temperature $(\mathrm{K})$. Regression of $\ln (\mathrm{k})$ versus $(1 / T)$ yields a slope of $E_{a} / R$, from which $E_{a}$ was readily calculated. As with half-lives, the use of PFO rate constants (such as $\mathrm{k}_{\mathrm{B}}$ ) carries the assumption that the "constant" reactant remains constant and the values of $\mathrm{A}$ and $\mathrm{E}_{\mathrm{a}}$ thus calculated are valid for only the specific concentration of "constant" reactant.

\subsubsection{Correction to Zero Headspace}

To account for the lack of hydrolysis occurring when CT or CF molecules are in the vapor phase, and therefore not in contact with water, the apparent rate constant, $\mathrm{k}_{\mathrm{app}}$, is adjusted by

$$
\mathrm{k}_{\mathrm{zhs}}=\mathrm{k}_{\mathrm{app}}\left[1+\mathrm{K}_{\mathrm{lv}}\left(\mathrm{V}_{\mathrm{v}} / \mathrm{V}_{\mathrm{l}}\right)\right]
$$

where $\mathrm{K}_{\mathrm{lv}}$ is the liquid-vapor partition coefficient for the temperature and pressure conditions of the experiment, $\mathrm{V}_{\mathrm{v}}$ is the volume of headspace, and $\mathrm{V}_{1}$ is the volume of liquid in the sealed reaction vessel. Values for $\mathrm{K}_{\mathrm{lv}}$ at each temperature were determined experimentally as described in Sections 2.3 and 3.0. Values for $\mathrm{V}_{\mathrm{v}}$ and $\mathrm{V}_{1}$ were also determined for each hydrolysis experiment as described in Section 2.2.1. 


\subsection{Liquid-Vapor Partition Coefficients}

As discussed in Section 2.4.5, results obtained in vessels having headspace needed to be corrected to zero-headspace using a liquid-vapor partition coefficient to account for the lack of hydrolysis occurring for the fraction of CT or CF molecules in the vapor phase. For CT initially, we regressed published values for Henry's law constant $\left(\mathrm{K}_{\mathrm{H}}{ }^{\prime}\right)$ measured at temperatures of 10 to $35^{\circ} \mathrm{C}$ (Gossett 1987) to allow extrapolation to the higher temperatures of our experiments. However, results corrected in this manner using Equation 2.20 did not agree well with results obtained at SUNY-Cortland using zero-headspace reactors. Recognizing that Henry's law is strictly valid only at infinite dilution and ambient pressure, direct measurements of liquid-vapor partition coefficients $\left(\mathrm{K}_{\mathrm{lv}}\right)$ for both $\mathrm{CT}$ and $\mathrm{CF}$ at the concentrations and pressures used in our experiments were conducted at SUNY-Cortland and at PNNL in an attempt to provide experimental values valid at the temperatures of our joint experiments.

The results of the $\mathrm{K}_{\mathrm{lv}}$ measurements for CT are plotted in an Arrhenius-type plot (Figure 3.1), along with $\mathrm{K}_{\mathrm{H}}{ }^{\prime}$ data (measured and extrapolated) of Gossett (1987), and $\mathrm{K}_{\mathrm{H}}{ }^{\prime}$ values calculated using an equation derived by Staudinger and Roberts (2001) from a critical review of nine studies including Gossett (1987). The $\mathrm{K}_{\mathrm{lv}}$ results obtained by SUNY and PNNL are in excellent agreement, which is remarkable given that the measurements were made by entirely different methods, one focused on solution-phase data and the other on vapor-phase data (Figure 3.1). The published values for $\mathrm{K}_{\mathrm{H}}{ }^{\prime}$ from the literature (Gossett, 1987; Staudinger and Roberts, 2001) also are in excellent agreement with each other. Although the

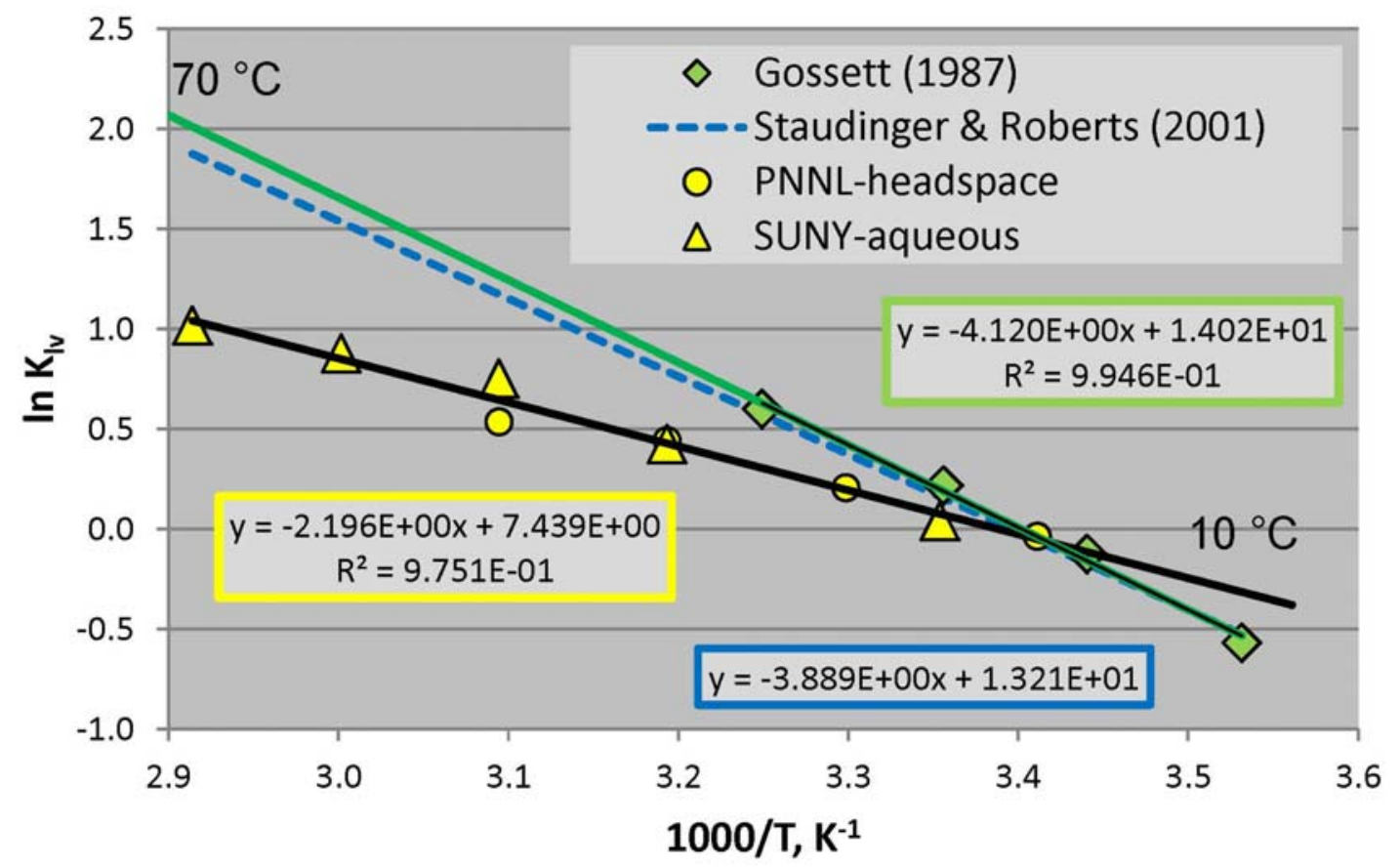

Figure 3.1. Values of $\mathrm{K}_{\mathrm{H}}{ }^{\prime}$ for Carbon Tetrachloride Determined and Extrapolated to Higher Temperatures from Gossett (1987) and Staudinger and Roberts (2001), Together with Empirical Determinations of $\mathrm{K}_{\mathrm{lv}}$ at SUNY-Cortland and PNNL by Measurements in the Aqueous and Vapor Phases, Respectively. 
published $\mathrm{K}_{\mathrm{H}}$ ' data and the empirical $\mathrm{K}_{\mathrm{lv}}$ data collected in this study agree well at near-ambient temperatures, they diverge progressively and significantly at temperatures above $30^{\circ} \mathrm{C}$, differing by more than a factor of 2 at the highest temperatures.

Development of a theoretical understanding of the factors leading to the differences between published $\mathrm{K}_{\mathrm{H}}{ }^{\prime}$ data and the empirical $\mathrm{K}_{\mathrm{lv}}$ data generated in this study was beyond the scope of the project. The excellent agreement between the SUNY-Cortland and PNNL determinations of $\mathrm{K}_{\mathrm{lv}}$, coupled with equally impressive agreement between the SUNY-Cortland and PNNL rate constants after correction using the empirical $\mathrm{K}_{\mathrm{lv}}$ data, suggest that the empirical $\mathrm{K}_{\mathrm{lv}}$ data are appropriate for our experiments. We therefore regressed the empirical data to obtain a working equation for estimation of $\mathrm{K}_{\mathrm{lv}}$ for $\mathrm{CT}$ at the temperatures used in our experiments.

$$
\mathrm{K}_{\mathrm{lv}}(\mathrm{CT})=\exp [(-2196 / \mathrm{T})+7.439]
$$

where $\mathrm{T}$ is in degrees Kelvin.

A similar situation exists for $\mathrm{CF}$, although the size of the correction factor is much less. A total of 32 separate aqueous-phase measurements were made at SUNY that sampled essentially the entire range of temperatures and concentrations of our CF hydrolysis-rate experiments. Three vapor-phase measurements were made at PNNL at $20.5^{\circ} \mathrm{C}$ in deionized water, Hanford groundwater, and Hanford sediment suspended in Hanford groundwater. The PNNL results were identical (+/- 0.001) for all three systems, and exactly matched the value of 0.139 calculated by the Gorgenyi equation (2002). Unfortunately, limited resources prevented additional measurements by the PNNL approach at other temperatures. The mean values obtained for $\mathrm{K}_{\mathrm{lv}}$ are shown in Figure 3.2, together with values for $\mathrm{K}_{\mathrm{H}}{ }^{\prime}$ (measured and extrapolated) of Gorgenyi et al. (2002) and predicted values from Staudinger and Roberts (2001).

Clearly, the $\mathrm{K}_{\mathrm{lv}}$ results we have obtained and the $\mathrm{K}_{\mathrm{H}}{ }^{\prime}$ values of Gorgenyi et al. (2002) and Staudinger and Roberts (2001) for CF differ at temperatures above about $35^{\circ} \mathrm{C}$. Gorgenyi et al. (2002) collected data from 2 to $60^{\circ} \mathrm{C}$ with strong statistical power. The database supporting the Staudinger and Roberts (2001) data, however, is limited to temperatures between 2 and $35^{\circ} \mathrm{C}$, adding considerable uncertainty to the values obtained by extrapolation of their equation to higher temperatures. Finally, the statistical power of the empirical $\mathrm{K}_{\mathrm{lv}}$ data for $\mathrm{CF}$ collected on this project is much poorer than was obtained for CT. For these reasons, we decided to use the $\mathrm{K}_{\mathrm{H}}$ ' data of Gorgenyi et al. (2002) to correct observed rate constants for headspace effects in the CF experiments. We fit a cubic polynomial $\left(r^{2}=0.9995\right)$ to the Gorgenyi et al. (2002) data to allow exact interpolation and extrapolation.

$$
\mathrm{K}_{\mathrm{lv}}(\mathrm{CF})=(2.687 \mathrm{e}-8) \mathrm{T}^{3}+(9.212 \mathrm{e}-5) \mathrm{T}^{2}+(2.696 \mathrm{e}-3) \mathrm{T}+4.308 \mathrm{e}-2
$$

where $\mathrm{T}$ is in degrees $\mathrm{C}$. 


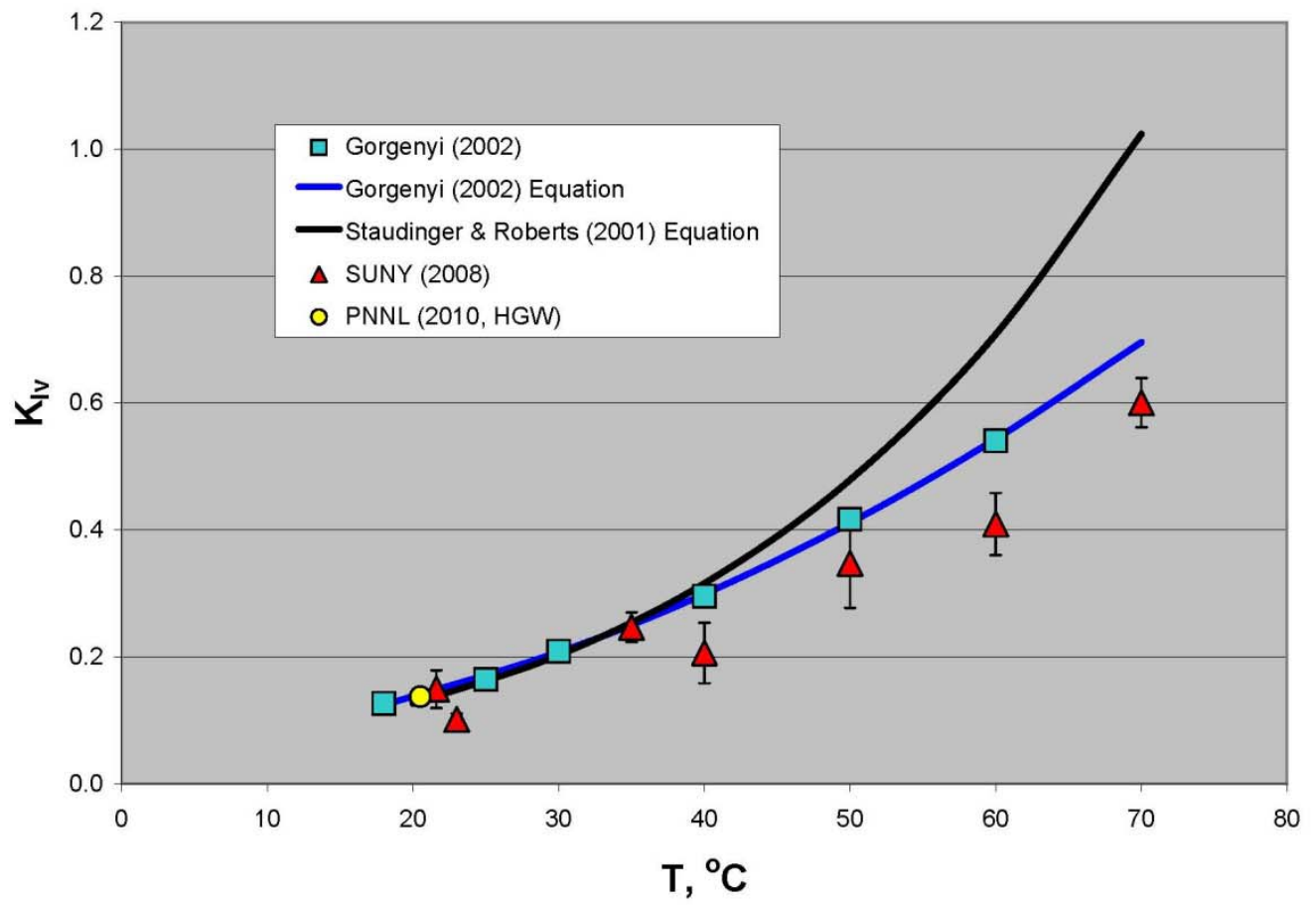

Figure 3.2. Mean Values of $\mathrm{K}_{\mathrm{lv}}$ for Chloroform Measured by SUNY-Cortland and PNNL, Together with $\mathrm{K}_{\mathrm{h}}$ Values for Chloroform Reported by Gorgenyi et al. (2002) and Predicted by the Staudinger and Roberts (2001) Equation. 



\subsection{Hydrolysis Rate Experiments}

In this section, we list all the experiments conducted and report rate constants and relevant parameters for statistically robust data sets. For the purpose of discussion, the experiments are grouped into four sections corresponding to whether $\mathrm{CT}$ or $\mathrm{CF}$ were being tested and whether the experiment involved homogeneous solutions or heterogeneous suspensions. To assess the statistical strength of each data set, we define the relative confidence in the rate constant, $\mathrm{RC}_{\mathrm{k}}$, as

$$
\mathrm{RC}_{\mathrm{k}}=\mathrm{k}_{\mathrm{zhs}} / \mathrm{CL}_{ \pm 95 \%}
$$

where $\mathrm{CL}_{ \pm 95 \%}$ is the $\pm 95 \%$ confidence interval calculated about the rate constant, $\mathrm{k}_{\mathrm{zhs}}$. When $\mathrm{RC}_{\mathrm{k}}>1$, the data set is considered robust. Generally, this criterion also corresponds to a probability of greater than 0.95 that $\mathrm{k}_{\mathrm{zhs}}$ is different from zero. A table at the front of each section lists the experiments and their corresponding $\mathrm{RC}_{\mathrm{k}}$ values, which are also shown graphically by the use of icons.

\subsection{Homogeneous Experiments with Carbon Tetrachloride}

More than 59 individual rate experiments were conducted in homogeneous solutions containing CT. Twenty-four of these, split evenly between deionized water and Hanford groundwater, were conducted at PNNL using sealed ampules with headspace, and more than 35 were conducted at SUNY-Cortland using minimum-headspace bulbs or the ZHR described in Section 2.2.2. Of the 35 experiments conducted at SUNY-Cortland, however, only the 11 most reliable experiments conducted in the ZHR (9 in deionized $\mathrm{H}_{2} \mathrm{O}$ and 2 in Hanford groundwater) are considered here. The approximate temperatures, aqueous medium, and initial CT concentrations for these experiments are listed in Table 4.1, along with the $\mathrm{RC}_{\mathrm{k}}$ values for each rate constant. Experiments with $\mathrm{RC}_{\mathrm{k}}<1$ are not considered further in this report.

Table 4.1. Conditions for Homogeneous Carbon Tetrachloride Hydrolysis Experiments and the Relative Confidence of the Rate Constants Obtained

\begin{tabular}{|c|c|c|c|c|c|c|}
\hline $\begin{array}{l}\text { Approximate } \\
\text { Temperature }\end{array}$ & $\begin{array}{c}\text { Deionized } \mathrm{H}_{2} \mathrm{O}, \\
\text { SUNY, } \\
\text { ppm CT varies }\end{array}$ & $\begin{array}{c}\text { Deionized } \mathrm{H}_{2} \mathrm{O} \\
9.8 \text { ppm CT }\end{array}$ & $\begin{array}{c}\text { Deionized } \mathrm{H}_{2} \mathrm{O} \\
152 \mathrm{ppm} \mathrm{CT}\end{array}$ & $\begin{array}{c}\text { Hanford } \\
\text { Groundwater, } \\
\text { SUNY, } \\
\text { ppm CT varies }\end{array}$ & $\begin{array}{c}\text { Hanford } \\
\text { Groundwater, } \\
49 \text { ppm CT }\end{array}$ & $\begin{array}{c}\text { Hanford } \\
\text { Groundwater, } \\
424 \text { ppm CT }\end{array}$ \\
\hline$-\cdots-{ }^{\circ} \mathrm{C}-\cdots$ & ---------- & - & $\mathrm{RC}_{\mathrm{k}}^{\dagger}$ & 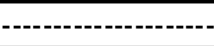 & 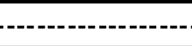 & --------- \\
\hline 93 & 18 & -- & -- & -- & -- & -- \\
\hline 88 & 52 & -- & -- & -- & -- & -- \\
\hline 80 & 135 & -- & -- & -- & -- & -- \\
\hline 70 & 32 & 11 & 11 & -- & 13 & 16 \\
\hline 60 & 56 & 7.3 & 12 & 3.6 & 2.7 & 16 \\
\hline 50 & 42 & 6.9 & 10 & 1.4 & 3.5 & 13 \\
\hline 50 & 35 & -- & -- & -- & -- & -- \\
\hline 40 & 15 & 2.5 & 8.2 & -- & 1.9 & 6.7 \\
\hline 30 & 13 & 0.6 & 3.0 & -- & 0.9 & 4.4 \\
\hline 20 & -- & 0.2 & 2.0 & -- & 0.1 & 3.4 \\
\hline
\end{tabular}

$\mathrm{TRC}_{\mathrm{k}}$ is the relative confidence in the rate constant, $\mathrm{k}$, as calculated using Equation 4.1. Black fill in circular icons corresponds to the following ranges in $\mathrm{RC}_{\mathrm{k}}$ values: $100 \%$ black $\left(\mathrm{RC}_{\mathrm{k}}>10\right), 75 \%$ black $\left(\mathrm{RC}_{\mathrm{k}}=5\right.$ to 10$)$, $50 \%$ black $\left(\mathrm{RC}_{\mathrm{k}}=2\right.$ to 5$), 25 \%$ black $\left(\mathrm{RC}_{\mathrm{k}}=1\right.$ to 2$), 0 \%$ black $\left(\mathrm{RC}_{\mathrm{k}}<1\right)$ 


\subsubsection{Deionized Water}

Experimental conditions, rate constants, 95\% confidence intervals, and headspace correction parameters for the 19 statistically robust datasets collected for CT in deionized water are shown in Table 4.2. The SUNY-Cortland data, being obtained with zero headspace, require no correction for headspace effects. For experiments conducted at PNNL, the apparent rate constant, $\mathrm{k}_{\text {app }}$, together with the ratio of gas volume to liquid volume inside the ampules $\left(\mathrm{V}_{\mathrm{v}} / \mathrm{V}_{\mathrm{l}}\right)$ and the value for $\mathrm{K}_{\mathrm{lv}}$ (calculated using Equation 3.1) that were used to correct $k_{a p p}$ to zero-headspace conditions by Equation 2.20 are given in addition to $\mathrm{k}_{\mathrm{zhs}}$.

Table 4.2. Rate Constants for Hydrolysis of Carbon Tetrachloride in Deionized Water

\begin{tabular}{|c|c|c|c|c|c|c|c|}
\hline $\begin{array}{l}\text { Temperature, } \\
{ }^{\circ} \mathrm{C}\end{array}$ & $\begin{array}{c}\text { Initial } \mathrm{CCl}_{4} \\
\text { Concentration, } \\
\mathrm{mg} \mathrm{L}^{-1}\end{array}$ & $\mathrm{Lab}$ & $\begin{array}{c}\mathrm{k}_{\text {app }}, \\
\mathrm{s}^{-1}\end{array}$ & $\begin{array}{c}\mathrm{k}_{\mathrm{zhs}}, \\
\mathrm{s}^{-1}\end{array}$ & $\begin{array}{c} \pm 95 \% \\
\text { Confidence } \\
\text { Interval, } \mathrm{s}^{-1} \\
\end{array}$ & $\mathrm{~V}_{\mathrm{v}} / \mathrm{V}_{1}$ & $\mathrm{~K}_{\mathrm{lv}}$ \\
\hline 93.0 & 369 & SUNY & -- & $3.49 \mathrm{e}-6$ & $1.94 \mathrm{e}-7$ & -- & -- \\
\hline 88.0 & 177 & SUNY & -- & $1.98 \mathrm{e}-6$ & $3.80 \mathrm{e}-8$ & -- & -- \\
\hline 80.5 & 67 & SUNY & -- & $8.51 \mathrm{e}-7$ & $6.32 \mathrm{e}-9$ & -- & -- \\
\hline 70.0 & 148 & SUNY & -- & $2.20 \mathrm{e}-7$ & $6.87 \mathrm{e}-9$ & -- & -- \\
\hline 70.0 & 152 & PNNL & $7.77 \mathrm{e}-8$ & $1.82 \mathrm{e}-7$ & $6.80 \mathrm{e}-9$ & 0.476 & 2.830 \\
\hline 70.0 & 9.8 & PNNL & $9.48 \mathrm{e}-8$ & $2.22 \mathrm{e}-7$ & $8.36 \mathrm{e}-9$ & 0.476 & 2.830 \\
\hline 60.0 & 350 & SUNY & -- & $5.63 \mathrm{e}-8$ & $1.01 \mathrm{e}-9$ & -- & -- \\
\hline 60.1 & 152 & PNNL & $2.31 \mathrm{e}-8$ & $4.89 \mathrm{e}-8$ & $2.01 \mathrm{e}-9$ & 0.476 & 2.340 \\
\hline 60.2 & 9.8 & PNNL & $2.48 \mathrm{e}-8$ & $5.25 \mathrm{e}-8$ & $3.42 \mathrm{e}-9$ & 0.476 & 2.341 \\
\hline 50.0 & 350 & SUNY & -- & $1.87 \mathrm{e}-8$ & $4.41 \mathrm{e}-10$ & -- & -- \\
\hline 50.0 & 327 & SUNY & -- & $1.34 \mathrm{e}-8$ & $3.81 \mathrm{e}-10$ & -- & -- \\
\hline 50.3 & 152 & PNNL & $5.91 \mathrm{e}-9$ & $1.13 \mathrm{e}-8$ & $6.02 \mathrm{e}-10$ & 0.476 & 1.917 \\
\hline 50.3 & 9.8 & PNNL & $7.03 \mathrm{e}-9$ & $1.34 \mathrm{e}-8$ & $1.02 \mathrm{e}-9$ & 0.476 & 1.916 \\
\hline 40.0 & 340 & SUNY & -- & $2.30 \mathrm{e}-9$ & $1.49 \mathrm{e}-10$ & -- & -- \\
\hline 40.5 & 152 & PNNL & $1.51 \mathrm{e}-9$ & $2.62 \mathrm{e}-9$ & $1.84 \mathrm{e}-10$ & 0.476 & 1.551 \\
\hline 40.6 & 9.8 & PNNL & $1.10 \mathrm{e}-9$ & $1.91 \mathrm{e}-9$ & $4.32 \mathrm{e}-10$ & 0.476 & 1.551 \\
\hline 30.0 & 315 & SUNY & -- & $3.59 \mathrm{e}-10$ & $2.86 \mathrm{e}-11$ & -- & -- \\
\hline 30.3 & 152 & PNNL & $4.65 \mathrm{e}-10$ & $7.36 \mathrm{e}-10$ & $1.57 \mathrm{e}-10$ & 0.476 & 1.225 \\
\hline 20 & 152 & PNNL & $5.55 \mathrm{e}-11$ & $8.08 \mathrm{e}-11$ & $2.84 \mathrm{e}-11$ & 0.476 & 0.956 \\
\hline
\end{tabular}

The earlier high-temperature data published by Jeffers et al. (1996) were not corrected for headspace, as this was assumed to have negligible effect in his minimum-headspace bulbs. Recent measurements of the headspace in similar bulbs suggest that a headspace-to-liquid ratio of 0.02 would make a reasonable estimate for the earlier work. To help compare the values obtained in the current project with those from the earlier work, we have calculated $\mathrm{k}_{\text {zhs }}$ values for the Jeffers et al. (1996) data by the same approach used for the PNNL data. Table 4.3 summarizes these data. 
To visualize the current data in comparison to the earlier high-temperature data of Jeffers et al. (1996), all the $\mathrm{k}_{\mathrm{zhs}}$ values are shown in an Arrhenius plot along with the $\mathrm{k}_{\text {app }}$ values for the hightemperature data (Figure 4.1). Although the high-temperature data on the upper left-hand side of the plot are affected by the headspace correction, even with only $2 \%$ headspace, when these data are extrapolated to lower temperatures (dashed lines), only slightly better agreement with the 2009 - 2012 data is obtained for the headspace-corrected 1996 data than for the original $k_{\text {app }}$ data reported by Jeffers et al. (1996).

Table 4.3. Rate Constants for Hydrolysis of Carbon Tetrachloride in Deionized Water at High Temperatures as Reported by Jeffers et al. (1996) $\left(\mathrm{k}_{\mathrm{app}}\right)$ and as Corrected for an Assumed 2\% Headspace-to-Liquid Ratio Using Extrapolated Values of $\mathrm{K}_{\mathrm{lv}}\left(\mathrm{k}_{\mathrm{zhs}}\right)$

\begin{tabular}{|c|c|c|c|c|}
\hline Temperature, ${ }^{\circ} \mathrm{C}$ & $\begin{array}{c}\text { Nominal Initial } \mathrm{CCl}_{4} \\
\text { Concentration, } \\
\mathrm{mg} \mathrm{L}^{-1}\end{array}$ & $\mathrm{k}_{\mathrm{app}}, \mathrm{s}^{-1}$ & $\mathrm{k}_{\mathrm{zhs}}, \mathrm{s}^{-1}$ & $\mathrm{~K}_{\mathrm{lv}}$ \\
\hline 163.0 & 40 & $1.04 \mathrm{e}-3$ & $1.28 \mathrm{e}-3$ & 11.069 \\
\hline 163.0 & 40 & $7.29 \mathrm{e}-4$ & $8.90 \mathrm{e}-4$ & 11.069 \\
\hline 149.7 & 40 & $3.92 \mathrm{e}-4$ & $4.66 \mathrm{e}-4$ & 9.445 \\
\hline 142.5 & 40 & $2.15 \mathrm{e}-4$ & $2.52 \mathrm{e}-4$ & 8.632 \\
\hline 130.9 & 40 & $9.19 e-5$ & $1.06 \mathrm{e}-4$ & 7.418 \\
\hline 120.4 & 40 & $3.85 e-5$ & $4.35 \mathrm{e}-5$ & 6.417 \\
\hline 110.6 & 40 & $1.68 \mathrm{e}-5$ & $1.87 \mathrm{e}-5$ & 5.563 \\
\hline 98.0 & 40 & $4.67 e-6$ & $5.10 \mathrm{e}-6$ & 4.586 \\
\hline 85.0 & 40 & $8.36 e-7$ & $8.98 \mathrm{e}-7$ & 3.698 \\
\hline
\end{tabular}

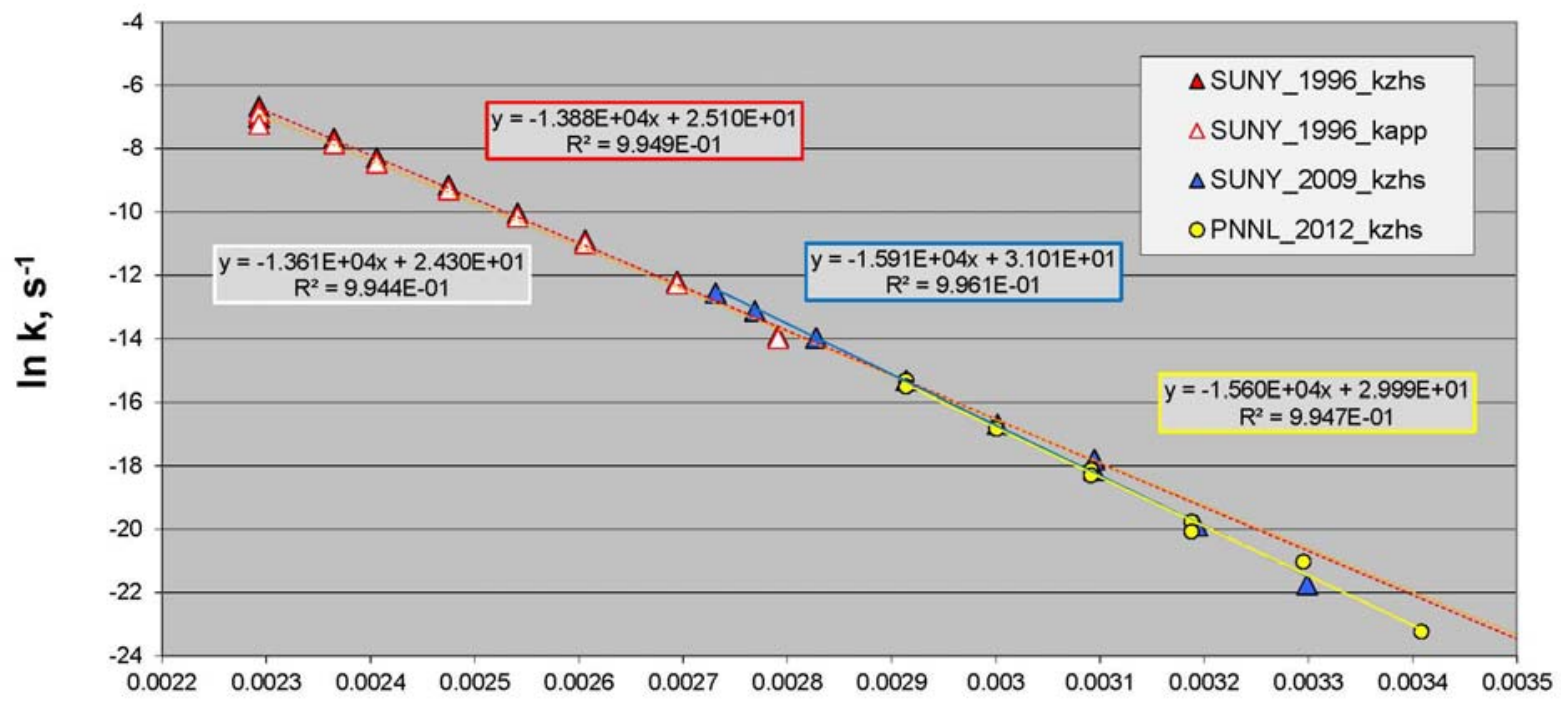

$1 / \mathrm{T}, \mathrm{K}^{-1}$

Figure 4.1. Arrhenius Plot of $\mathrm{k}_{\mathrm{zhs}}$ Data for Deionized Water Generated in This Study Along with $\mathrm{k}_{\mathrm{app}}$ Data as Reported by Jeffers et al. (1996) and the 1996 Data Normalized to $\mathrm{k}_{\text {zhs }}$ Assuming a $2 \%$ Headspace-to-Liquid Ratio and the Extrapolated Values of $\mathrm{K}_{\mathrm{lv}}$ (Table 4.3). Blue Triangles are SUNY Data for Deionized Water Using Zero-Headspace Reactors. 
Overall, the measured rate constants are slower than those that would have been predicted by extrapolation of the $1996 \mathrm{k}_{\text {app }}$ data to lower temperature (i.e., the dashed orange line in Figure 4.1). For example, the Arrhenius equation,

$$
\mathrm{k}=\mathrm{Ae}^{(-\mathrm{Ea} / \mathrm{RT})}
$$

where $\mathrm{A}$ is the pre-exponential factor $\left(\mathrm{s}^{-1}\right), \mathrm{E}_{\mathrm{a}}$ is the activation energy $\left(\mathrm{J} \mathrm{mol}^{-1}\right), \mathrm{R}$ is the gas constant $\left(8.314 \mathrm{~J} \mathrm{~mol}^{-1} \mathrm{~K}^{-1}\right)$, and $\mathrm{T}$ is the temperature $(\mathrm{K})$, predicts from the $1996 \mathrm{k}_{\text {app }}$ data a rate of $4.77 \mathrm{e}-9 \mathrm{~s}^{-1}$ at $40^{\circ} \mathrm{C}$, whereas the measured SUNY $\mathrm{k}_{\text {zhs }}$ value is $2.30 \mathrm{e}-9 \mathrm{~s}^{-1}$, a factor of 2.1 slower. For comparison to previous published analyses that have represented rate constants as half-life values, we converted the rate constants shown in Table 4.2 to equivalent half-life values at $16^{\circ} \mathrm{C}$ using

$$
\mathrm{t}_{1 / 2}=\ln (2) / \mathrm{k}
$$

and listed them, with proportionally adjusted $\pm 95 \%$ confidence intervals, in Table 4.4.

Table 4.4. Half-Life Values for Hydrolysis of Carbon Tetrachloride in Deionized Water Based on Rate Constants Listed in Table 4.2

\begin{tabular}{lcccc}
\hline $\begin{array}{c}\text { Temperature, } \\
{ }^{\circ} \mathrm{C}\end{array}$ & $\begin{array}{c}\text { Initial CCl } \\
\text { Concentration, } \\
\mathrm{mg} \mathrm{L}^{-1}\end{array}$ & $\mathrm{Lab}$ & $\begin{array}{c}\text { using } \mathrm{k}_{\mathrm{zhs}}, \\
\mathrm{yr}\end{array}$ & $\begin{array}{c} \pm 95 \% \text { Confidence } \\
\text { Interval, } \\
\text { yr }\end{array}$ \\
\hline 93.0 & 369 & SUNY & 0.006 & $3.5 \mathrm{e}-4$ \\
88.0 & 177 & SUNY & 0.011 & $2.1 \mathrm{e}-4$ \\
80.5 & 67 & SUNY & 0.026 & $1.9 \mathrm{e}-4$ \\
70.0 & 148 & SUNY & 0.100 & $3.1 \mathrm{e}-3$ \\
70.0 & 152 & PNNL & 0.121 & $4.5 \mathrm{e}-3$ \\
70.0 & 9.8 & PNNL & 0.099 & $3.7 \mathrm{e}-3$ \\
60.0 & 350 & SUNY & 0.39 & $7.0 \mathrm{e}-3$ \\
60.1 & 152 & PNNL & 0.45 & 0.019 \\
60.2 & 9.8 & PNNL & 0.42 & 0.027 \\
50.0 & 350 & SUNY & 1.2 & 0.028 \\
50.0 & 327 & SUNY & 1.6 & 0.047 \\
50.3 & 152 & PNNL & 1.9 & 0.10 \\
50.3 & 9.8 & PNNL & 1.6 & 0.13 \\
40.0 & 340 & SUNY & 9.6 & 0.62 \\
40.5 & 152 & PNNL & 8.4 & 0.59 \\
40.6 & 9.8 & PNNL & 11 & 2.6 \\
30.0 & SUNY & 61 & 4.9 \\
30.2 & 152 & PNNL & 30 & 6.4 \\
20 & & PNNL & 270 & 96 \\
\hline & & & & \\
\hline
\end{tabular}




\subsubsection{Groundwater}

The hydrolysis data for Hanford groundwater are summarized in Tables 4.5 (rate constants) and 4.6 (half-lives).

Table 4.5. Rate Constants for Hydrolysis of Carbon Tetrachloride in Hanford Groundwater

\begin{tabular}{lccccccc}
\hline $\begin{array}{l}\text { Temperature, } \\
{ }^{\circ} \mathrm{C}\end{array}$ & $\begin{array}{c}\text { Initial CCl } \\
\text { Concentration, } \\
\mathrm{mg} \mathrm{L}^{-1}\end{array}$ & Lab & $\begin{array}{c}\mathrm{k}_{\text {app }}, \\
\mathrm{s}^{-1}\end{array}$ & $\begin{array}{c}\mathrm{k}_{\text {zhs }}, \\
\mathrm{s}^{-1}\end{array}$ & $\begin{array}{c} \pm 95 \% \\
\text { Confidence } \\
\text { Interval, } \mathrm{s}^{-1}\end{array}$ & $\mathrm{~V}_{\mathrm{v}} / \mathrm{V}_{\mathrm{l}}$ & $\mathrm{K}_{\mathrm{lv}}$ \\
\hline 70.1 & 424 & PNNL & $6.34 \mathrm{e}-8$ & $1.50 \mathrm{e}-7$ & $3.86 \mathrm{e}-9$ & 0.479 & 2.834 \\
69.8 & 49 & PNNL & $8.57 \mathrm{e}-8$ & $2.02 \mathrm{e}-7$ & $6.57 \mathrm{e}-9$ & 0.480 & 2.816 \\
60 & 436 & SUNY & -- & $4.61 \mathrm{e}-8$ & $1.29 \mathrm{e}-8$ & -- & -- \\
60.1 & 424 & PNNL & $1.79 \mathrm{e}-8$ & $3.79 \mathrm{e}-8$ & $1.12 \mathrm{e}-9$ & 0.479 & 2.339 \\
60.1 & 49 & PNNL & $1.72 \mathrm{e}-8$ & $3.65 \mathrm{e}-8$ & $6.39 \mathrm{e}-9$ & 0.480 & 2.340 \\
50.4 & 424 & PNNL & $4.17 \mathrm{e}-9$ & $8.00 \mathrm{e}-9$ & $3.30 \mathrm{e}-10$ & 0.479 & 1.920 \\
50.4 & 49 & PNNL & $6.75 \mathrm{e}-9$ & $1.30 \mathrm{e}-8$ & $1.95 \mathrm{e}-9$ & 0.480 & 1.920 \\
48.6 & 503 & SUNY & -- & $1.38 \mathrm{e}-8$ & $9.57 \mathrm{e}-9$ & & -- \\
40.4 & 424 & PNNL & $1.20 \mathrm{e}-9$ & $2.09 \mathrm{e}-9$ & $1.79 \mathrm{e}-10$ & 0.479 & 1.546 \\
40.4 & 49 & PNNL & $1.77 \mathrm{e}-9$ & $3.08 \mathrm{e}-9$ & $9.37 \mathrm{e}-10$ & 0.480 & 1.545 \\
30.2 & 424 & PNNL & $2.15 \mathrm{e}-10$ & $3.40 \mathrm{e}-10$ & $4.93 \mathrm{e}-11$ & 0.479 & 1.221 \\
20.3 & 424 & PNNL & $4.76 \mathrm{e}-11$ & $6.94 \mathrm{e}-11$ & $1.40 \mathrm{e}-11$ & 0.479 & 0.956 \\
\hline
\end{tabular}

Table 4.6. Half-Life Values for Hydrolysis of Carbon Tetrachloride in Hanford Site Groundwater Based on Rate Constants Listed in Table 4.5

\begin{tabular}{|c|c|c|c|c|}
\hline $\begin{array}{l}\text { Temperature, } \\
{ }^{\circ} \mathrm{C}\end{array}$ & $\begin{array}{l}\text { Initial } \mathrm{CCl}_{4} \text { Concentration, } \\
\mathrm{mg} \mathrm{L}^{-1}\end{array}$ & $\mathrm{Lab}$ & $\begin{array}{c}\mathrm{t}_{1 / 2} \text { using } \mathrm{k}_{\mathrm{zhs}}, \\
\mathrm{yr}\end{array}$ & $\begin{array}{c} \pm 95 \% \text { Confidence } \\
\text { Interval, } \\
\text { yr }\end{array}$ \\
\hline 70.1 & 424 & PNNL & 0.15 & $3.8 \mathrm{e}-3$ \\
\hline 69.8 & 49 & PNNL & 0.11 & $3.5 \mathrm{e}-3$ \\
\hline 60 & 402 & SUNY & 0.47 & -- \\
\hline 60.1 & 424 & PNNL & 0.58 & 0.017 \\
\hline 60.1 & 49 & PNNL & 0.60 & 0.11 \\
\hline 50.4 & 424 & PNNL & 2.7 & 0.11 \\
\hline 50.4 & 49 & PNNL & 1.7 & 0.25 \\
\hline 48.6 & 464 & SUNY & 1.6 & -- \\
\hline 40.4 & 424 & PNNL & 11 & 0.90 \\
\hline 40.4 & 49 & PNNL & 7.1 & 2.2 \\
\hline 30.2 & 424 & PNNL & 65 & 9.4 \\
\hline 20.3 & 424 & PNNL & 315 & 64 \\
\hline
\end{tabular}




\subsubsection{Summary of Homogeneous Results for Carbon Tetrachloride}

All the robust rate constants obtained for CT in homogeneous solution during this project are plotted in Arrhenius format in Figure 4.2. Arrhenius parameters for each type of data (deionized water or Hanford groundwater, SUNY or PNNL) and various combinations thereof are given in Table 4.7. As can be seen from the plot and from comparison of the activation energies, there is no substantial difference between the results obtained in deionized water and those obtained in Hanford groundwater, nor between results obtained in ZHRs at SUNY-Cortland and those obtained in sealed ampules with headspace at PNNL.

We thus treat all the homogeneous rate constant results determined in this project as a single data set for which Arrhenius parameters (bottom line, Table 4.7) as well as 95\% confidence bands (Figure 4.2) can be calculated. This result will be used in the next section to determine whether contact with sediment and minerals surfaces has a significant effect on CT hydrolysis rates.

Also given in Table 4.7 are Arrhenius parameters for the previous results of Jeffers et al. (1996), with and without correction for headspace effects. As suggested by Figure 4.1, the headspace corrections are minor, and the Jeffers et al. (1996) data are distinctly different from those obtained on the current project, with substantially lower activation energies and pre-exponential factors.

Finally, Table 4.7 lists the corresponding half-lives at $16^{\circ} \mathrm{C}$ calculated for each of the data sets by using the Arrhenius parameters to estimate the rate constants and then inserting them into

$$
\mathrm{t}_{1 / 2}=\ln (2) / \mathrm{k}
$$

These clearly show about a 3.5-fold difference in rate between the original extrapolated data of Jeffers et al. (1996) and that estimated on this project. Unfortunately, it seems, at groundwater temperatures CT hydrolyzes even more slowly than previously thought. 


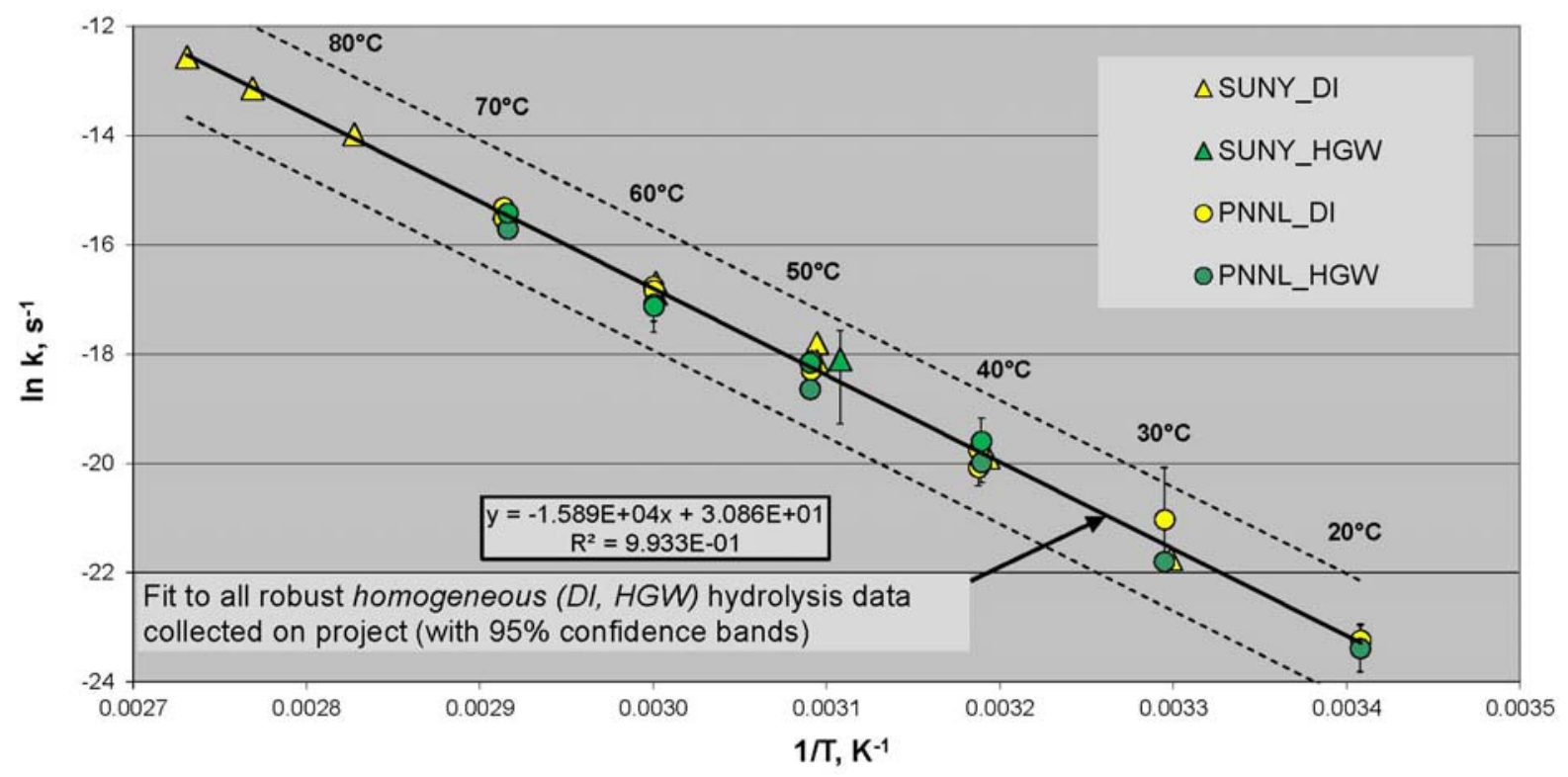

Figure 4.2. Arrhenius Plot of All Robust $\mathrm{k}_{\mathrm{zhs}}$ Data for Carbon Tetrachloride Hydrolysis in Deionized Water (DI) and Hanford Groundwater (HGW) Generated in This Study at SUNY-Cortland (SUNY) and PNNL. Error Bars are 95\% Confidence Intervals.

Table 4.7. Arrhenius Parameters for Hydrolysis of Carbon Tetrachloride in Homogeneous Aqueous Solution (Deionized Water and Groundwater) and Corresponding Half-Lives Estimated for $16^{\circ} \mathrm{C}$

\begin{tabular}{lccc}
\hline Dataset & $\mathrm{E}_{\mathrm{a}}, \mathrm{kJ} \mathrm{mol}^{-1}$ & $\mathrm{~A}^{-1}$ & $\mathrm{t}_{1 / 2}\left(16^{\circ} \mathrm{C}\right), \mathrm{yr}$ \\
\hline Deionized $\mathrm{H}_{2} \mathrm{O}$, Jeffers et al. (1996), $\mathrm{k}_{\mathrm{app}}$ & 113 & $3.6 \mathrm{e} 10$ & 170 \\
Deionized $\mathrm{H}_{2} \mathrm{O}$, Jeffers et al. (1996), $\mathrm{k}_{\text {zhs }}$ & 115 & $8.0 \mathrm{e} 10$ & 190 \\
Deionized $\mathrm{H}_{2} \mathrm{O}, \mathrm{SUNY}, \mathrm{k}_{\text {zhs }}$ & 132 & $2.9 \mathrm{e} 13$ & 590 \\
Deionized $\mathrm{H}_{2} \mathrm{O}$, PNNL, $\mathrm{k}_{\text {zhs }}$ & 130 & $1.1 \mathrm{e} 13$ & 550 \\
Deionized $\mathrm{H}_{2} \mathrm{O}$, All SUNY-PNNL, $\mathrm{k}_{\text {zhs }}$ & 132 & $2.2 \mathrm{e} 13$ & 580 \\
Hanford Groundwater, All SUNY-PNNL, $\mathrm{k}_{\text {zhs }}$ & 132 & $1.9 \mathrm{e} 13$ & 680 \\
All Homogeneous SUNY-PNNL, $\mathrm{k}_{\text {zhs }}$ & 132 & $2.5 \mathrm{e} 13$ & 630 \\
\hline
\end{tabular}




\subsection{Homogeneous Experiments with Chloroform}

A total of 27 homogeneous experiments with chloroform were conducted to determine rate constants for neutral and base-catalyzed hydrolysis (Table 4.8). Ten experiments were conducted at $\mathrm{pH} 3.3$ in dilute $\mathrm{H}_{2} \mathrm{SO}_{4}$ to quantify the neutral hydrolysis rate constants. Another ten experiments were conducted in $0.1 \mathrm{M}$ sodium phosphate buffered at either $\mathrm{pH} 8$ or $\mathrm{pH}$ 12. These 20 experiments in $\mathrm{H}_{2} \mathrm{SO}_{4}$ or sodium phosphate were conducted at PNNL in sealed ampules with nominal headspace. The remaining 7 experiments were conducted in 0.01 molal sodium hydroxide at SUNY-Cortland using a ZHR. The approximate temperatures, aqueous medium, and initial CF concentrations for the homogeneous $\mathrm{CF}$ experiments are listed in Table 4.8, along with the $\mathrm{RC}_{\mathrm{k}}$ values for each rate constant. Experiments with $\mathrm{RC}_{\mathrm{k}}<1$ are not considered further in this report.

The robust rate data from 26 homogeneous CF experiments are summarized in Table 4.9 and Table 4.10, along with the initial reactant concentrations and the dimensionless $\mathrm{K}_{\mathrm{lv}}$ values derived from Gorgenyi et al. (2002). An Arrhenius plot of the homogeneous CF experimental data is given in Figure 4.3.

Table 4.8. Conditions for Homogeneous Chloroform Hydrolysis Experiments and the Relative Confidence of the Rate Constants Obtained

\begin{tabular}{|c|c|c|c|c|c|}
\hline $\begin{array}{l}\text { Approximate } \\
\text { Temperature }\end{array}$ & $\begin{array}{c}\mathrm{pH} 3, \\
41 \mathrm{ppm} \mathrm{CF}, \\
0.3 \mathrm{mM} \mathrm{H}_{2} \mathrm{SO}_{4}\end{array}$ & $\begin{array}{c}\mathrm{pH} 3, \\
337 \mathrm{ppm} \mathrm{CF}, \\
0.3 \mathrm{mM} \mathrm{H}_{2} \mathrm{SO}_{4}\end{array}$ & $\begin{array}{c}\text { pH } 8, \\
204 \text { ppm CF, } \\
\text { 0.1 M phosphate }\end{array}$ & $\begin{array}{c}\text { pH } 12, \\
\text { ppm CF varies, } \\
0.1 \text { M phosphate }\end{array}$ & $\begin{array}{c}\text { pH 12, } \\
\text { ppm CF varies, } \\
0.01 \text { molal } \\
\mathrm{NaOH}\end{array}$ \\
\hline \multicolumn{6}{|l|}{---- ${ }^{\circ} \mathrm{C}$---- } \\
\hline 70 & 39 & 52 & 40 & -- & -- \\
\hline 60 & 22 & 29 & 54 & -- & 43 \\
\hline 55 & -- & -- & -- & -- & 31 \\
\hline 50 & 6.6 & 13 & 40 & 33 & -- \\
\hline 40 & 1.7 & 1.8 & 60 & 44 & 50 \\
\hline 40 & -- & -- & -- & -- & 144 \\
\hline 30 & -- & 2.6 & 33 & 36 & 96 \\
\hline 30 & -- & -- & -- & -- & 19 \\
\hline 20 & -- & 0.6 & 8.2 & 39 & 59 \\
\hline
\end{tabular}

$\uparrow \mathrm{RC}_{\mathrm{k}}$ is the relative confidence in the rate constant, $\mathrm{k}$, as calculated using Equation 4.1. Black fill in circular icons corresponds to the following ranges in $\mathrm{RC}_{\mathrm{k}}$ values: $100 \%$ black $\left(\mathrm{RC}_{\mathrm{k}}>10\right), 75 \%$ black $\left(\mathrm{RC}_{\mathrm{k}}=5\right.$ to 10$), 50 \%$ black $\left(\mathrm{RC}_{\mathrm{k}}=2\right.$ to 5$), 25 \%$ black $\left(\mathrm{RC}_{\mathrm{k}}=1\right.$ to 2$), 0 \%$ black $\left(\mathrm{RC}_{\mathrm{k}}<1\right)$ 
Table 4.9. Rate Constants for Neutral Homogeneous Hydrolysis of Chloroform

\begin{tabular}{lcccccc}
\hline $\begin{array}{l}\text { Temperature, } \\
{ }^{\circ} \mathrm{C}\end{array}$ & $\begin{array}{c}\text { Initial } \mathrm{CHCl}_{3} \\
\text { Concentration, } \\
\mathrm{mg} \mathrm{L}^{-1}\end{array}$ & $\begin{array}{c}\mathrm{k}_{\text {app }}, \\
\left(0.3 \mathrm{mM} \mathrm{H}_{2} \mathrm{SO}_{4}\right), \\
\mathrm{s}^{-1}\end{array}$ & $\begin{array}{c}\mathrm{k}_{\mathrm{N}}, \\
\left(0.3 \mathrm{mM} \mathrm{H}_{2} \mathrm{SO}_{4}\right), \\
\mathrm{s}^{-1}\end{array}$ & $\begin{array}{c} \pm 95 \% \text { Confidence } \\
\text { Interval, } \\
\mathrm{L} \mathrm{mol}^{-1} \mathrm{~s}^{-1}\end{array}$ & $\mathrm{~V}_{\mathrm{v}} / \mathrm{V}_{\mathrm{l}}$ & $\mathrm{K}_{\mathrm{lv}}$ \\
\hline 70.1 & 41 & $1.84 \mathrm{e}-9$ & $2.44 \mathrm{e}-9$ & $6.19 \mathrm{e}-11$ & 0.474 & 0.694 \\
70.1 & 337 & $2.10 \mathrm{e}-9$ & $2.81 \mathrm{e}-9$ & $5.35 \mathrm{e}-11$ & 0.486 & 0.694 \\
60.1 & 41 & $4.13 \mathrm{e}-10$ & $5.20 \mathrm{e}-10$ & $2.32 \mathrm{e}-11$ & 0.474 & 0.544 \\
60.1 & 337 & $5.15 \mathrm{e}-10$ & $6.51 \mathrm{e}-10$ & $2.23 \mathrm{e}-11$ & 0.486 & 0.544 \\
50.0 & 41 & $9.95 \mathrm{e}-11$ & $1.19 \mathrm{e}-10$ & $1.81 \mathrm{e}-11$ & 0.474 & 0.412 \\
50.0 & 337 & $1.36 \mathrm{e}-10$ & $1.63 \mathrm{e}-10$ & $1.26 \mathrm{e}-11$ & 0.486 & 0.412 \\
40.2 & 41 & $2.34 \mathrm{e}-11$ & $2.67 \mathrm{e}-11$ & $1.56 \mathrm{e}-11$ & 0.474 & 0.302 \\
40.2 & 337 & $2.59 \mathrm{e}-11$ & $2.97 \mathrm{e}-11$ & $1.69 \mathrm{e}-11$ & 0.486 & 0.302 \\
30.2 & 337 & $1.91 \mathrm{e}-11$ & $2.11 \mathrm{e}-11$ & $7.98 \mathrm{e}-12$ & 0.486 & 0.209 \\
\hline
\end{tabular}

Table 4.10. Rate Constants for Base-Catalyzed Homogeneous Hydrolysis of Chloroform

\begin{tabular}{|c|c|c|c|c|c|c|c|c|}
\hline $\begin{array}{l}\text { Temper- } \\
\text { ature, } \\
{ }^{\circ} \mathrm{C}\end{array}$ & $\begin{array}{c}\text { Initial } \\
\mathrm{CHCl}_{3} \\
\text { Concentra- } \\
\text { tion, } \\
\mathrm{mg} \mathrm{L}^{-1}\end{array}$ & $\mathrm{Lab}$ & $\begin{array}{l}\text { Initial } \mathrm{OH}^{-} \\
\text {Concentra- } \\
\text { tion, } \\
\text { mol L }^{-1}\end{array}$ & $\begin{array}{c}\text { Phosphate } \\
\text { Concentra- } \\
\text { tion, } \\
\text { mol L }^{-1}\end{array}$ & $\begin{array}{c}\mathrm{k}_{\mathrm{B}}, \\
\mathrm{L} \mathrm{mol}^{-1} \mathrm{~s}^{-1}\end{array}$ & $\begin{array}{c} \pm 95 \% \\
\text { Confi- } \\
\text { dence } \\
\text { Interval, } \\
\text { L mol }^{-1} \mathrm{~s}^{-1}\end{array}$ & $\mathrm{~V}_{\mathrm{v}} / \mathrm{V}_{1}$ & $\mathrm{~K}_{\mathrm{lv}}$ \\
\hline 70.1 & 205 & PNNL & $1.54 \mathrm{e}-6$ & 0.10 & $3.18 \mathrm{e}-1$ & $8.00 \mathrm{e}-3$ & 0.486 & 0.694 \\
\hline 60.5 & 205 & PNNL & $1.54 \mathrm{e}-6$ & 0.10 & $5.90 \mathrm{e}-2$ & $1.09 \mathrm{e}-3$ & 0.486 & 0.550 \\
\hline 60 & 58 & SUNY & $9.73 e-3$ & -- & $8.63 \mathrm{e}-3$ & $2.01 \mathrm{e}-4$ & -- & -- \\
\hline 55 & 156 & SUNY & $9.59 \mathrm{e}-3$ & -- & $4.60 \mathrm{e}-3$ & $1.47 \mathrm{e}-4$ & -- & -- \\
\hline 50.0 & 205 & PNNL & $1.54 \mathrm{e}-6$ & 0.10 & $9.61 \mathrm{e}-3$ & $2.41 \mathrm{e}-4$ & 0.486 & 0.412 \\
\hline 50 & 359 & PNNL & $1.79 \mathrm{e}-2$ & 0.10 & $4.83 \mathrm{e}-3$ & $1.48 \mathrm{e}-4$ & 0.477 & 0.412 \\
\hline 40.2 & 205 & PNNL & $1.54 \mathrm{e}-6$ & 0.10 & $1.25 \mathrm{e}-3$ & $2.08 \mathrm{e}-5$ & 0.486 & 0.302 \\
\hline 40 & 153 & SUNY & $9.59 \mathrm{e}-3$ & -- & $5.36 \mathrm{e}-4$ & $1.07 \mathrm{e}-5$ & -- & -- \\
\hline 40 & 58 & SUNY & $9.74 \mathrm{e}-3$ & -- & $5.18 \mathrm{e}-4$ & $3.58 \mathrm{e}-6$ & -- & -- \\
\hline 40.5 & 295 & PNNL & $1.79 \mathrm{e}-2$ & 0.10 & $1.10 \mathrm{e}-3$ & $2.50 \mathrm{e}-5$ & 0.477 & 0.305 \\
\hline 30.15 & 50 & SUNY & $1.01 \mathrm{e}-2$ & -- & $1.22 \mathrm{e}-4$ & $1.28 \mathrm{e}-6$ & -- & -- \\
\hline 30 & 189 & SUNY & $9.74 \mathrm{e}-3$ & -- & $1.00 \mathrm{e}-4$ & $5.42 \mathrm{e}-6$ & -- & -- \\
\hline 30.2 & 205 & PNNL & $1.54 \mathrm{e}-6$ & 0.10 & $1.59 \mathrm{e}-4$ & $4.80 \mathrm{e}-6$ & 0.486 & 0.209 \\
\hline 29.6 & 283 & PNNL & $1.79 \mathrm{e}-2$ & 0.10 & $1.55 \mathrm{e}-4$ & $4.27 \mathrm{e}-6$ & 0.477 & 0.204 \\
\hline 22 & 153 & SUNY & $9.59 \mathrm{e}-3$ & -- & $3.09 \mathrm{e}-5$ & $5.20 \mathrm{e}-7$ & -- & -- \\
\hline 20.4 & 205 & PNNL & $1.54 \mathrm{e}-6$ & 0.10 & $2.51 \mathrm{e}-5$ & $3.06 \mathrm{e}-6$ & 0.486 & 0.136 \\
\hline 19.9 & 360 & PNNL & $1.79 \mathrm{e}-2$ & 0.10 & $1.80 \mathrm{e}-5$ & $4.60 \mathrm{e}-7$ & 0.477 & 0.133 \\
\hline
\end{tabular}




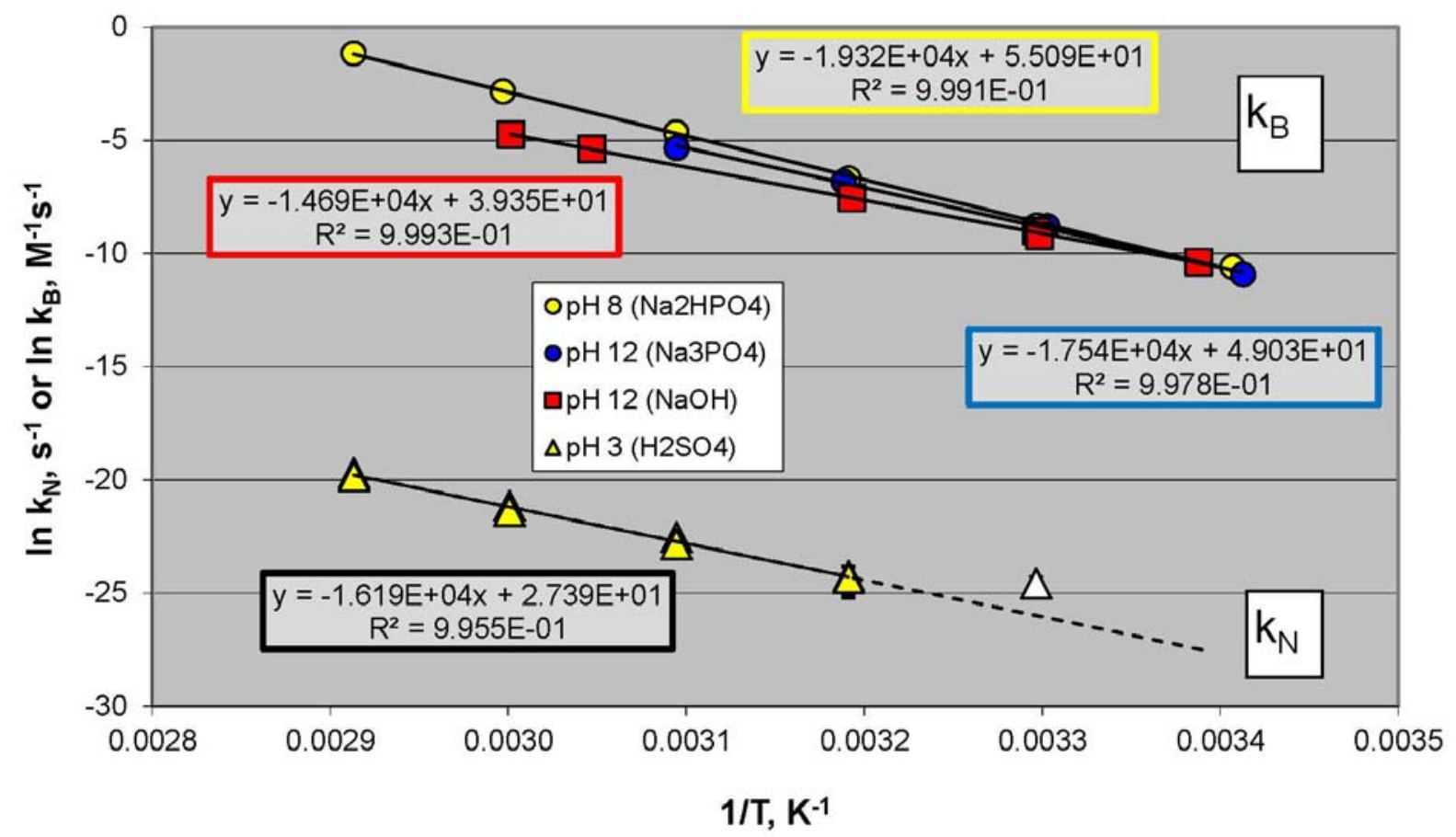

Figure 4.3. Arrhenius Plot of All Homogeneous Hydrolysis Data ( $\left.\mathrm{k}_{\mathrm{zhs}}\right)$ for Chloroform. Error bars represent $\pm 95 \%$ confidence intervals. White triangle is $\mathrm{pH} 3$ datum not included in Arrhenius regression.

The neutral hydrolysis results (Table 4.9, $\mathrm{k}_{\mathrm{N}}$ in Figure 4.3) show excellent agreement between the experiments conducted at the same temperature, even though the initial CF concentrations differ by a factor of ten. This result is consistent with expectations that solute concentration has negligible impact on liquid-vapor partition coefficients (Schwarzenbach et al. 1993, pp. 112 -114) and hence on the amount of solute in contact with water, the hydrolyzing agent.

We note, however, that datum from one experiment $\left(\right.$ at $\left.30.2^{\circ} \mathrm{C}\right)$ plotted as a white triangle in Figure 4.3, did not conform to the expected Arrhenius relation shown by the other eight $\mathrm{pH} 3$ experiments, even though the relative confidence of the measurement was considered robust. We excluded this datum from the Arrhenius relation for $\mathrm{k}_{\mathrm{N}}$ on the basis of a $\mathrm{Q}$ test (Rorabacher, 1991; 95\% confidence) on the residuals from the regression analysis. That is, the difference between the measured rate constant at $30.2^{\circ} \mathrm{C}$ and that calculated using the regression equation for the other eight rate constants accounted for $89 \%$ of the total range in residual values for the nine rate constants, well above the Q-test criterion of $49.3 \%$.

An Arrhenius plot of the base-catalyzed homogeneous rate data is shown in Figure 4.4. One would expect similar $\mathrm{k}_{\mathrm{B}}$ values for the three experiments, and a fair agreement is observed. However, from this plot and Table 4.10, it is clear that the rates in the two phosphate-buffered systems have a temperature dependence that differs from the temperature dependence in $\mathrm{NaOH}$. This effect is due to the nucleophilic character of hydrogen phosphate $\left(\mathrm{HPO}_{4}{ }^{2-}\right)$ ion, which is about twice as great as that for hydroxyl ion, and thus can initiate hydrolysis-like reactions that would release $\mathrm{Cl}^{-}$ions to solution (Swain and Scott 1953; Schwarzenbach et al. 1993, pp. $359-365)$. Differences in the speciation of phosphate with $\mathrm{pH}(60 \%$ 


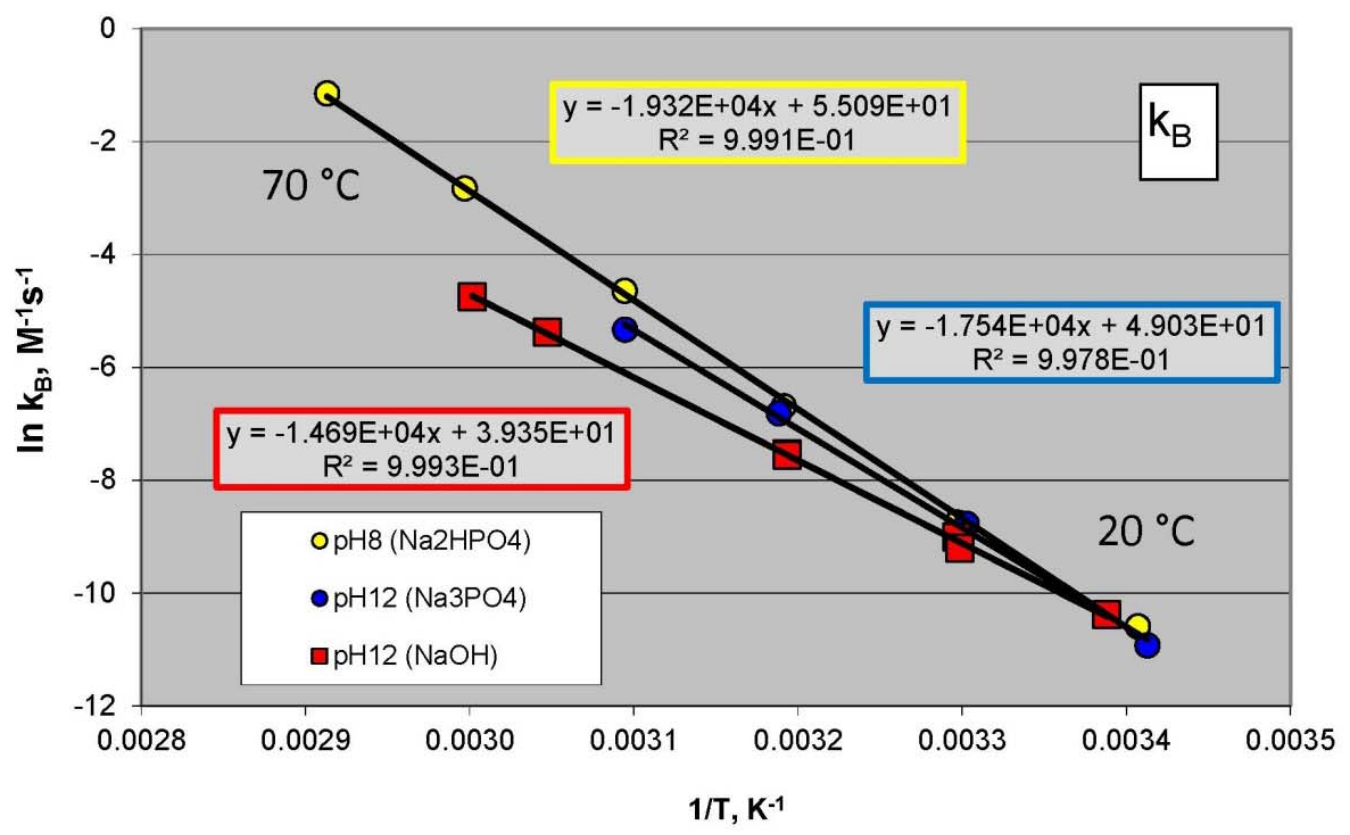

Figure 4.4. Arrhenius Plot of Base-Catalyzed Homogeneous Hydrolysis Data $\left(\mathrm{k}_{\mathrm{zhs}}\right)$ for Chloroform. $\mathrm{HPO}_{4}{ }^{2-}$ at $\mathrm{pH} 8.05$ and $11 \% \mathrm{HPO}_{4}{ }^{2-}$ at $\mathrm{pH} 12.11$ ) could account for the consistently higher rates at $\mathrm{pH} 8$ than $\mathrm{pH}$ 12. Apparently the protonated phosphate ions are much stronger nucleophiles than the $\mathrm{PO}_{4}{ }^{3-}$ ion and ion pairs that form at $\mathrm{pH} 12$.

Because we are interested in the base-catalyzed rate constants, not the additional catalytic effect of phosphate, we will use the data collected in $\mathrm{NaOH}$ for further calculations. The good agreement between $\mathrm{NaOH}$ and $\mathrm{pH} 80.1-\mathrm{M}$ phosphate data at $20^{\circ} \mathrm{C}$ suggests that neither $\mathrm{HPO}_{4}{ }^{2-}$ nor $\mathrm{HCO}_{3}{ }^{-}$, which has roughly equivalent nucleophilicity (Schwarzenbach et al. 1993, p. 359) and is ubiquitous in groundwater, will impact the base-catalyzed reaction rate in groundwater significantly.

The activation energies for base-catalyzed CF hydrolysis are $122 \mathrm{KJ} \mathrm{mol}^{-1}$ for the $0.01 \mathrm{molal} \mathrm{NaOH}$ experiments at $\mathrm{pH} 12,146 \mathrm{~kJ} \mathrm{~mol}^{-1}$ for the experiments in $0.1 \mathrm{M}$ phosphate at $\mathrm{pH} 12$, and $161 \mathrm{~kJ} \mathrm{~mol}^{-1}$ for experiments in $0.1 \mathrm{M}$ phosphate at $\mathrm{pH}$. These compare with a value of $105 \mathrm{~kJ} \mathrm{~mol}^{-1}$ reported from hightemperature experiments by Jeffers et al. (1989) using minimal-headspace (about 2\%) ampules without correction for Henry's law.

The homogeneous hydrolysis data for $\mathrm{CF}$ hydrolysis show that two factors, temperature and $\mathrm{pH}$, have a strong bearing on the rate at which it degrades. With the Arrhenius' expressions for both $\mathrm{k}_{\mathrm{N}}$ and $\mathrm{k}_{\mathrm{B}}$ in hand, we can calculate overall rate constants and corresponding half-lives for any combination of temperature or $\mathrm{pH}$ within or near the range measured using

$$
-\mathrm{d}\left[\mathrm{CHCl}_{3}\right] / \mathrm{dt}=\left(\mathrm{k}_{\mathrm{N}}+\mathrm{k}_{\mathrm{B}}\left[\mathrm{OH}^{-}\right]\right)\left[\mathrm{CHCl}_{3}\right]
$$

A plot of data for temperatures between $10^{\circ} \mathrm{C}$ and $70^{\circ} \mathrm{C}$, and $\mathrm{pH}$ values between 5 and 10 is given in Figure 4.5. For reference, the typical $\mathrm{pH}$ and temperature of Hanford groundwater are shown by the 


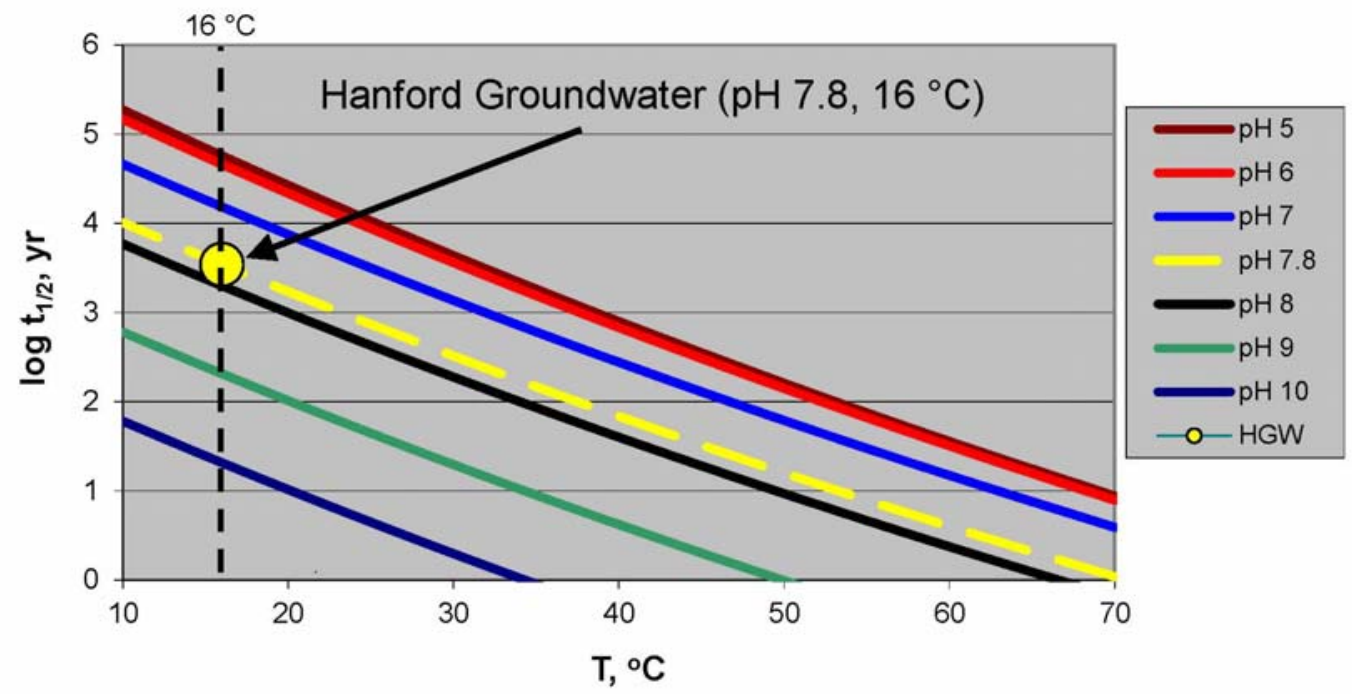

Figure 4.5. Impact of Temperature and $\mathrm{pH}$ on Hydrolysis Half-life Predicted for Chloroform From Homogeneous Rate Data Developed in This Project.

yellow data point, and the impact of temperature alone on hydrolysis half-life in Hanford groundwater is given by the dashed yellow line. From this plot, we infer that either an increase in $\mathrm{pH}$ of about one unit or an increase in temperature of about $15^{\circ} \mathrm{C}$ will decrease the hydrolysis half-life of CF by an order of magnitude.

\subsection{Heterogeneous Experiments with Carbon Tetrachloride}

A total of 24 experiments involving CT reacting in Hanford groundwater in the presence of a Hanford Site sediment or specific minerals were conducted at PNNL in sealed ampules with headspace (Table 4.11). Eight of the experimental sets, in two separate runs started in fiscal year (FY) 2007 and early FY 2010, involved a Hanford Site sediment. The other 16 sets involved specific minerals selected to be representative of those found in Hanford Site sediments as discussed in Section 2.1. The approximate temperatures, suspended material, and initial CT concentrations for the heterogeneous CT experiments are listed in Table 4.11, along with relative confidence $\left(\mathrm{RC}_{\mathrm{k}}\right)$ values for each rate constant. Experiments with $\mathrm{RC}_{\mathrm{k}}<1$ are not considered further in this report.

Six of the Hanford-Site sediment experiments, three from each run, yielded robust rate data. The rate constants are summarized in Table 4.12 along with initial reactant concentrations and headspace correction parameters. Half-life values and their associated confidence intervals for these six experiments are given in Table 4.13. 
Table 4.11. Conditions for Heterogeneous Carbon Tetrachloride Hydrolysis Experiments and the Relative Confidence of the Rate Constants Obtained

\begin{tabular}{|c|c|c|c|c|c|c|}
\hline $\begin{array}{l}\text { Approximate } \\
\text { Temperature }\end{array}$ & $\begin{array}{c}\text { Hanford } \\
\text { Sediment, } \\
265 \text { ppm CT }\end{array}$ & $\begin{array}{c}\text { Hanford } \\
\text { Sediment, } \\
367 \text { ppm CT }\end{array}$ & $\begin{array}{c}\text { Montmorillonite, } \\
410 \text { ppm CT }\end{array}$ & $\begin{array}{l}\text { Kaolinite, } \\
368 \text { ppm CT }\end{array}$ & $\begin{array}{c}\text { Albite, } \\
375 \text { ppm CT }\end{array}$ & $\begin{array}{l}\text { Muscovite, } \\
311 \text { ppm CT }\end{array}$ \\
\hline$-\cdots{ }^{\circ} \mathrm{C} \quad----$ & - ------ & - & $\mathrm{RC}_{\mathrm{k}}$ & 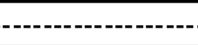 & - & -------- \\
\hline 50 & 10 & -- & ( $\quad 8.3$ & 7.9 & 24 & 17 \\
\hline 40 & 6.2 & -- & 8.7 & 11.2 & 8.8 & 7.5 \\
\hline 35 & -- & 9.5 & -- & -- & -- & -- \\
\hline 30 & 3.9 & 2.7 & 5.2 & 3.8 & 3.6 & 5.5 \\
\hline 25 & -- & 3.5 & -- & -- & -- & -- \\
\hline 20 & 0.4 & 0.4 & 1.6 & 1.4 & 2.4 & 2.8 \\
\hline
\end{tabular}

$\left\lceil\mathrm{RC}_{\mathrm{k}}\right.$ is the relative confidence in the rate constant, $\mathrm{k}$, as calculated using Equation 4.1. Black fill in circular icons corresponds to the following ranges in $\mathrm{RC}_{\mathrm{k}}$ values: $100 \%$ black $\left(\mathrm{RC}_{\mathrm{k}}>10\right), 75 \%$ black $\left(\mathrm{RC}_{\mathrm{k}}=5\right.$ to 10$)$, $50 \%$ black $\left(\mathrm{RC}_{\mathrm{k}}=2\right.$ to 5$), 25 \%$ black $\left(\mathrm{RC}_{\mathrm{k}}=1\right.$ to 2$), 0 \%$ black $\left(\mathrm{RC}_{\mathrm{k}}<1\right)$

Table 4.12. Rate Constants for Hydrolysis of Carbon Tetrachloride in Suspensions of Hanford Site Sediment in Hanford Groundwater

\begin{tabular}{lcccccc}
\hline & $\begin{array}{c}\text { Initial CCl } \\
\text { Concentration, } \\
\mathrm{mg} \mathrm{L}^{-1}\end{array}$ & $\mathrm{k}_{\text {app }}, \mathrm{s}^{-1}$ & $\mathrm{k}_{\text {zhs }}, \mathrm{s}^{-1}$ & $\begin{array}{c} \pm 95 \% \\
\text { Confidence } \\
\text { Interval, } \mathrm{s}^{-1}\end{array}$ & $\mathrm{~V}_{\mathrm{v}} / \mathrm{V}_{\mathrm{l}}$ & $\mathrm{K}_{\mathrm{lv}}$ \\
\hline 50.4 & 265 & $6.66 \mathrm{e}-9$ & $1.23 \mathrm{e}-8$ & $6.35 \mathrm{e}-10$ & 0.439 & 1.918 \\
40.3 & 265 & $1.65 \mathrm{e}-9$ & $2.77 \mathrm{e}-9$ & $2.66 \mathrm{e}-10$ & 0.439 & 1.543 \\
33.1 & 367 & $1.25 \mathrm{e}-9$ & $1.87 \mathrm{e}-9$ & $1.32 \mathrm{e}-10$ & 0.381 & 1.309 \\
30.9 & 367 & $5.60 \mathrm{e}-10$ & $8.25 \mathrm{e}-10$ & $2.04 \mathrm{e}-10$ & 0.381 & 1.243 \\
30.1 & 265 & $3.87 \mathrm{e}-10$ & $5.94 \mathrm{e}-10$ & $1.00 \mathrm{e}-10$ & 0.439 & 1.219 \\
24.8 & 367 & $1.52 \mathrm{e}-10$ & $2.14 \mathrm{e}-10$ & $4.29 \mathrm{e}-11$ & 0.381 & 1.072 \\
\hline
\end{tabular}

Table 4.13. Half-Life Values for Hydrolysis of Carbon Tetrachloride in Suspensions of Hanford Site Sediment in Hanford Site Groundwater Based on Rate Constants in Table 4.12

\begin{tabular}{lccc}
\hline & $\begin{array}{c}\text { Initial } \mathrm{CCl}_{4} \text { Concentration, } \\
\mathrm{mg} \mathrm{L}^{-1}\end{array}$ & $\begin{array}{c}\mathrm{t}_{1 / 2} \text { using } \mathrm{zh}_{\mathrm{hs}}, \\
\mathrm{yr}\end{array}$ & $\begin{array}{c}\text { Interval, } \\
\mathrm{yr}\end{array}$ \\
\hline 50.4 & 265 & 1.8 & 0.09 \\
40.3 & 265 & 7.9 & 0.8 \\
33.1 & 367 & 12 & 0.8 \\
30.9 & 367 & 27 & 7 \\
30.1 & 265 & 37 & 6 \\
24.8 & 367 & 100 & 21 \\
\hline
\end{tabular}


The remaining 16 heterogeneous experiments with CT involve four minerals representative of the Hanford Site as pure phases. Twelve experiments were started in FY 2007 and the remaining four in early FY 2008. All the experiments involve suspensions of minerals in Hanford groundwater. The rate constants for the pure-mineral-phase experiments are summarized in Table 4.14 along with initial reactant concentrations and headspace correction parameters.

To assess whether hydrolysis of CT is subject to heterogeneous catalysis, all the heterogeneous CT rate constants from Tables 4.12 and 4.14 are plotted in Arrhenius format in Figure 4.6, along with the regression line with $95 \%$ confidence bands for all the robust homogeneous CT hydrolysis rate constants that was first plotted in Figure 4.2. Although one of the rate constants for Hanford Sediment is considerably higher than the homogeneous rate data regression line, and the $20^{\circ} \mathrm{C}$ rate constants for the pure-mineral-phase experiments tend to be lower, none of the heterogeneous rate constants obtained in this study fall outside of the $95 \%$ confidence bands associated with the homogeneous rate data. The results of the heterogeneous experiments thus show there is no statistically significant evidence $(\mathrm{P}>0.95)$ for a heterogeneous effect on CT hydrolysis by either Hanford sediment or the four minerals selected to be representative of those found in the sediment.

Table 4.14. Rate Constants for Hydrolysis of Carbon Tetrachloride in Suspensions of Minerals in Hanford Groundwater

\begin{tabular}{|c|c|c|c|c|c|c|c|}
\hline Mineral Phase & $\begin{array}{c}\text { Temper- } \\
\text { ature, } \\
{ }^{\circ} \mathrm{C}\end{array}$ & $\begin{array}{c}\text { Initial } \\
\mathrm{CCl}_{4} \\
\text { Concen- } \\
\text { tration, } \\
\mathrm{mg} \mathrm{L}^{-1} \\
\end{array}$ & $\begin{array}{c}\mathrm{k}_{\text {app }}, \\
\mathrm{s}^{-1}\end{array}$ & $\begin{array}{c}\mathrm{k}_{\mathrm{zhhs}}, \\
\mathrm{s}^{-1}\end{array}$ & $\begin{array}{c} \pm 95 \% \\
\text { Confi- } \\
\text { dence } \\
\text { Interval, } \\
\mathrm{s}^{-1} \\
\end{array}$ & $\mathrm{~V}_{\mathrm{v}} / \mathrm{V}_{1}$ & $\mathrm{~K}_{\mathrm{lv}}$ \\
\hline Muscovite & 49.9 & 311 & $3.63 e-9$ & $9.94 \mathrm{e}-9$ & $2.09 \mathrm{e}-10$ & 0.458 & 1.899 \\
\hline Kaolinite & 49.9 & 368 & $3.62 \mathrm{e}-9$ & $9.92 \mathrm{e}-9$ & $4.56 \mathrm{e}-10$ & 0.457 & 1.900 \\
\hline Albite & 49.9 & 375 & $3.55 \mathrm{e}-9$ & $9.71 \mathrm{e}-9$ & $1.48 \mathrm{e}-10$ & 0.441 & 1.900 \\
\hline Montmorillonite & 49.9 & 410 & $3.57 \mathrm{e}-9$ & $9.76 \mathrm{e}-9$ & $4.32 \mathrm{e}-10$ & 0.457 & 1.901 \\
\hline Muscovite & 40.0 & 311 & $9.86 \mathrm{e}-10$ & $2.13 e-9$ & $1.31 \mathrm{e}-10$ & 0.458 & 1.533 \\
\hline Kaolinite & 40.1 & 368 & $9.57 \mathrm{e}-10$ & $2.07 \mathrm{e}-9$ & $8.57 \mathrm{e}-11$ & 0.457 & 1.534 \\
\hline Albite & 40.1 & 375 & $9.59 \mathrm{e}-10$ & $2.07 \mathrm{e}-9$ & $1.09 \mathrm{e}-10$ & 0.441 & 1.534 \\
\hline Montmorillonite & 40.1 & 410 & $9.98 \mathrm{e}-10$ & $2.15 \mathrm{e}-9$ & $1.15 \mathrm{e}-10$ & 0.457 & 1.534 \\
\hline Muscovite & 30.1 & 311 & $2.05 \mathrm{e}-10$ & $3.59 \mathrm{e}-10$ & $3.75 \mathrm{e}-11$ & 0.458 & 1.217 \\
\hline Kaolinite & 30.1 & 368 & $1.41 \mathrm{e}-10$ & $2.47 \mathrm{e}-10$ & $3.69 \mathrm{e}-11$ & 0.457 & 1.218 \\
\hline Albite & 30.1 & 375 & $1.80 \mathrm{e}-10$ & $3.15 \mathrm{e}-10$ & $4.98 \mathrm{e}-11$ & 0.441 & 1.218 \\
\hline Montmorillonite & 30.1 & 410 & $2.01 \mathrm{e}-10$ & $3.52 \mathrm{e}-10$ & $3.86 \mathrm{e}-11$ & 0.457 & 1.219 \\
\hline Muscovite & 20.3 & 311 & $3.63 \mathrm{e}-11$ & $5.35 \mathrm{e}-11$ & $1.28 \mathrm{e}-11$ & 0.458 & 0.957 \\
\hline Kaolinite & 20.3 & 368 & $2.29 \mathrm{e}-11$ & $3.37 \mathrm{e}-11$ & $1.59 \mathrm{e}-11$ & 0.457 & 0.957 \\
\hline Albite & 20.3 & 375 & $3.15 \mathrm{e}-11$ & $4.64 \mathrm{e}-11$ & $1.32 \mathrm{e}-11$ & 0.441 & 0.957 \\
\hline Montmorillonite & 20.3 & 410 & $2.83 e-11$ & $4.16 \mathrm{e}-11$ & $1.75 \mathrm{e}-11$ & 0.457 & 0.957 \\
\hline
\end{tabular}




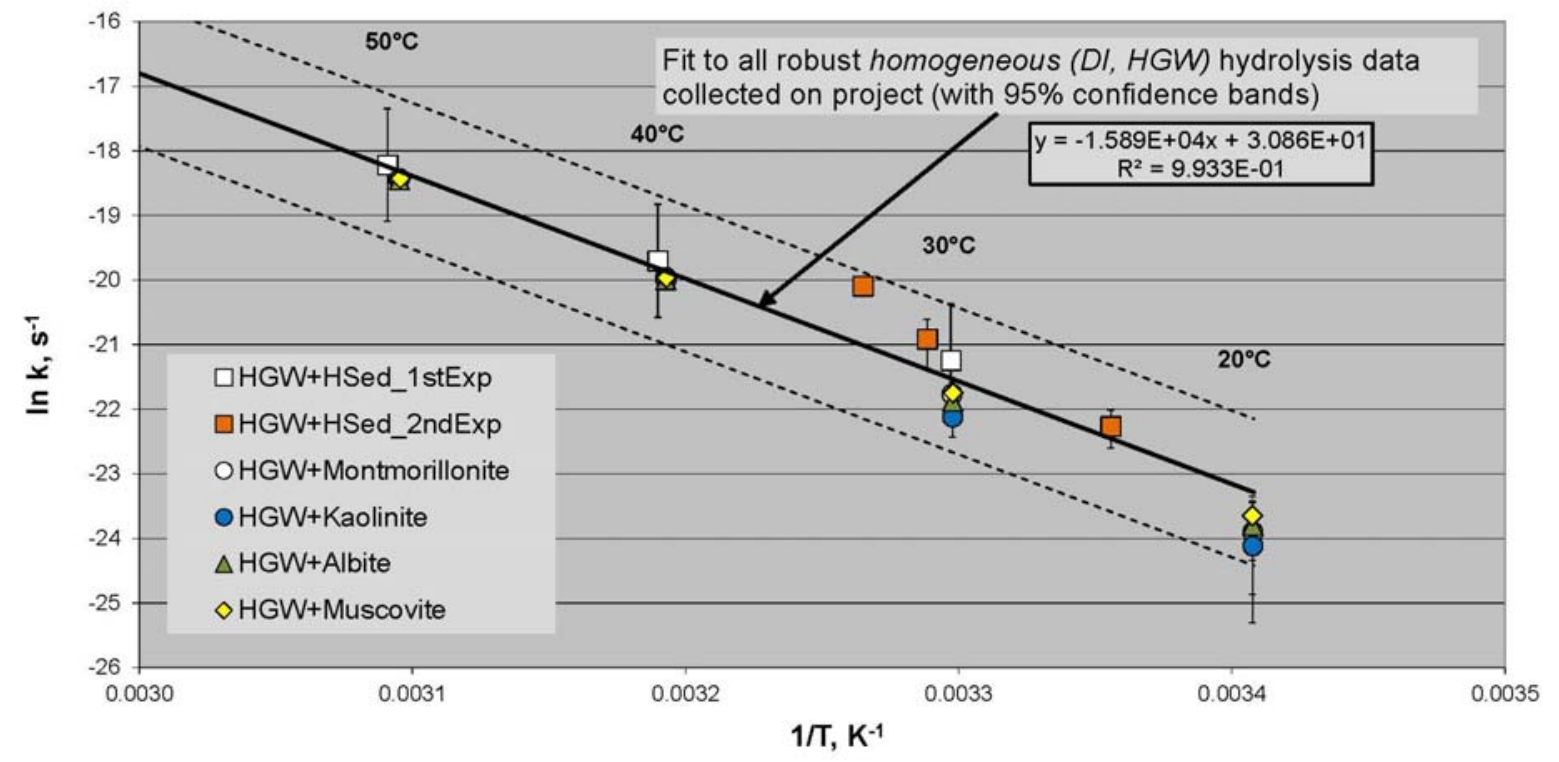

Figure 4.6. Arrhenius Plot of $\mathrm{k}_{\mathrm{zhs}}$ Data for Hydrolysis of Carbon Tetrachloride in Deionized Water, Hanford Groundwater, and Suspensions of Oxidized Hanford Sediment in Hanford Groundwater. Error Bars are 95\% Confidence Intervals.

\subsection{Heterogeneous Experiments with Chloroform}

A total of 28 experiments were conducted in sealed ampules with headspace at PNNL to determine the hydrolysis rates of chloroform in the suspensions of a Hanford sediment or the four minerals selected in Section 2.1 in Hanford groundwater. One set of experiments for each of the five solid phases was started in FY 2007 or early FY 2008. After two years of results it became apparent that $\mathrm{pH}$ was important, but that there was little attention paid to the initial $\mathrm{pH}$ status of the experiments. As a result, two more sets of experiments in which the initial $\mathrm{pH}$ was controlled very carefully were started in the middle of FY 2010. These last two experimental sets involved Hanford sediment and montmorillonite, and these solids were adjusted to an initial $\mathrm{pH}$ of 7.2 after cold sterilization with $15 \% \mathrm{H}_{2} \mathrm{O}_{2}$. The approximate temperatures, suspended material, and initial CF concentrations for the heterogeneous $\mathrm{CF}$ experiments are listed in Table 4.15, along with relative confidence $\left(\mathrm{RC}_{\mathrm{k}}\right)$ values for each rate constant. Experiments with $\mathrm{RC}_{\mathrm{k}}<1$ are not considered further in this report.

Robust rate constants were obtained for 27 of the heterogeneous CF hydrolysis experiments. These rate constants are "pseudo-first-order" rate constants, $\mathrm{k}_{\mathrm{pfo}}$, where

$$
\mathrm{k}_{\mathrm{pfo}}=\mathrm{k}_{\mathrm{N}}+\mathrm{k}_{\mathrm{B}}\left[\mathrm{OH}^{-}\right]
$$

and are listed in Table 4.16 along with the initial CF concentrations, $\pm 95 \%$ confidence intervals, and parameters associated with headspace corrections. 
Table 4.15. Conditions for Heterogeneous Chloroform Hydrolysis Experiments and the Relative Confidence of the Rate Constants Obtained

\begin{tabular}{|c|c|c|c|c|c|c|c|}
\hline $\begin{array}{l}\text { Approximate } \\
\text { Temperature }\end{array}$ & $\begin{array}{c}\text { Hanford } \\
\text { Sediment, } \\
476 \text { ppm CF }\end{array}$ & $\begin{array}{c}\text { Montmorillonite, } \\
385 \text { ppm CF }\end{array}$ & $\begin{array}{l}\text { Kaolinite, } \\
494 \text { ppm CF }\end{array}$ & $\begin{array}{c}\text { Albite, } \\
424 \text { ppm CF }\end{array}$ & $\begin{array}{l}\text { Muscovite, } \\
473 \text { ppm CF }\end{array}$ & $\begin{array}{c}\text { pH } 7.2, \\
\text { Hanford } \\
\text { Sediment, } \\
349 \text { ppm CF }\end{array}$ & $\begin{array}{c}\text { pH } 7.2, \\
\text { Montmorillonite, } \\
348 \text { ppm CF }\end{array}$ \\
\hline -..-- ${ }^{\circ} \mathrm{C}$-..-- & & - & - & $\mathrm{RC}_{\mathrm{k}}$ & 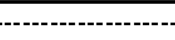 & (1) & - \\
\hline 50 & 22 & 3.1 & 32 & 12 12 & 17 & -- & -- \\
\hline 40 & 19 & 4.2 & 9.5 & 4.4 & 14 & -- & -- \\
\hline 35 & -- & -- & -- & -- & -- & 3.8 & 8.5 \\
\hline 30 & 5.2 & 1.9 & 5.7 & 7.3 & 6.6 & 5.1 & 3.7 \\
\hline 25 & -- & -- & -- & -- & -- & 2.0 & 3.6 \\
\hline 20 & 3.2 & 1.4 & 1.5 & 0.9 & 1.2 & 1.2 & 1.6 \\
\hline
\end{tabular}

$\mathrm{TRC}_{\mathrm{k}}$ is the relative confidence in the rate constant, $\mathrm{k}$, as calculated using Equation 4.1. Black fill in circular icons corresponds to the following ranges in $\mathrm{RC}_{\mathrm{k}}$ values: $100 \%$ black $\left(\mathrm{RC}_{\mathrm{k}}>10\right), 75 \%$ black $\left(\mathrm{RC}_{\mathrm{k}}=5\right.$ to 10$), 50 \%$ black $\left(\mathrm{RC}_{\mathrm{k}}=2\right.$ to 5$)$, $25 \%$ black $\left(\mathrm{RC}_{\mathrm{k}}=1\right.$ to 2$), 0 \%$ black $\left(\mathrm{RC}_{\mathrm{k}}<1\right)$

The heterogeneous CF pseudo-first-order rate constants are plotted in Arrhenius format in Figure 4.7. Also plotted are lines calculated for homogeneous solutions at $\mathrm{pHs}$ of 3, 6.1, 7.8, 8.6 and 8.8. The line calculations were done using Equation 4.5 to estimate $\mathrm{k}_{\mathrm{pfo}}$ from values for $\mathrm{k}_{\mathrm{N}}$ and $\mathrm{k}_{\mathrm{B}}$ (calculated by the Arrhenius equations shown in Figure 4.3) and a value for [OH-] derived assuming an ionic strength of Hanford groundwater of 0.025 (the single-ion activity coefficient for this assumption is 0.862 ).

In contrast to the relatively well-behaved mineral-specific rates obtained for $\mathrm{CT}$, the heterogeneous $\mathrm{k}_{\mathrm{pfo}}$ values obtained for CF varied substantially. For muscovite, kaolinite, and albite, the rate constants did not conform well to the Arrhenius equation. Substantially better Arrhenius behavior was observed for the Hanford sediment and for montmorillonite. As with the CF data for $\mathrm{k}_{\mathrm{N}}$ in Figure 4.3, one datum for Hanford sediment was excluded from the Arrhenius calculation on the basis of the Q-test $(95 \%$ confidence). The activation energy obtained for CF hydrolysis in the presence of Hanford sediment was $120 \mathrm{~kJ} \mathrm{~mol}^{-1}$, which is substantially the same as obtained for homogeneous base-catalyzed hydrolysis in 0.1 molal NaOH $\left(122 \mathrm{~kJ} \mathrm{~mol}^{-1}\right)$.

The most interesting results were those from the montmorillonite experiments. In the initial experimental set, rate constants substantially slower than those obtained for Hanford sediment and the other minerals were obtained. These conformed reasonably well to the Arrhenius equation, but at a much lower apparent activation energy (ca. $60 \mathrm{~kJ} \mathrm{~mol}^{-1}$ ). In the second experimental set, in which the montmorillonite was pre-equilibrated to a $\mathrm{pH}$ of 7.2 before starting the experiment, a similar apparent activation energy was obtained but the rate constants were substantially faster than those for the Hanford sediment and other minerals. The activation energy for Hanford sediment was unchanged by preequilibration to $\mathrm{pH} 7.2$, perhaps because this was near its original value.

The scatter in rate data obtained with these different heterogeneous systems likely stems from different $\mathrm{pH}$ values maintained by the minerals in contact with Hanford groundwater. To test this premise, we measured the $\mathrm{pH}$ of suspensions of the minerals and Hanford sediment in Hanford groundwater, which had a $\mathrm{pH}$ of 8.60 (this $\mathrm{pH}$ is about 0.85 unit higher than that recorded in the field and reported in Table 2.1, presumably due to degassing of $\mathrm{CO}_{2}$ from the sample during storage). For most minerals and the Hanford sediment, the $\mathrm{pH}$ dropped by 0.1 to 0.25 unit, and there was no correlation between the $\mathrm{pH}$ decrease and the difference between the rate constant and that obtained in homogeneous solution. For the original montmorillonite used in the first experimental set, however, a pH drop of 0.8 
Table 4.16. Pseudo-First-Order Rate Constants $\left(\mathrm{k}_{\mathrm{pfo}}\right)$ for Hydrolysis of Chloroform in Suspensions of Hanford Sediment or Specific Minerals in Hanford Groundwater

\begin{tabular}{|c|c|c|c|c|c|c|c|}
\hline $\begin{array}{l}\text { Sediment or } \\
\text { Mineral }\end{array}$ & $\begin{array}{l}\text { Temper- } \\
\text { ature, }{ }^{\circ} \mathrm{C} \\
\end{array}$ & $\begin{array}{c}\text { Initial } \mathrm{CHCl}_{3} \\
\text { Concentration, } \\
\mathrm{mg} \mathrm{L}^{-1} \\
\end{array}$ & $\mathrm{k}_{\mathrm{app}}, \mathrm{s}^{-1}$ & $\mathrm{k}_{\mathrm{zhs}}, \mathrm{s}^{-1}$ & $\begin{array}{c} \pm 95 \% \\
\text { Confidence } \\
\text { Interval, } \mathrm{s}^{-1} \\
\end{array}$ & $\mathrm{~V}_{\mathrm{v}} / \mathrm{V}_{1}$ & $\mathrm{~K}_{\mathrm{lv}}$ \\
\hline $\begin{array}{l}\text { Hanford } \\
\text { Sediment }\end{array}$ & 50.2 & 476 & $2.51 \mathrm{e}-9$ & $2.98 \mathrm{e}-9$ & $1.35 \mathrm{e}-10$ & 0.459 & 0.414 \\
\hline Muscovite & 49.9 & 473 & $2.32 \mathrm{e}-9$ & $2.75 \mathrm{e}-9$ & $1.64 \mathrm{e}-10$ & 0.458 & 0.411 \\
\hline Kaolinite & 49.9 & 495 & $1.22 \mathrm{e}-9$ & $1.44 \mathrm{e}-9$ & $4.44 \mathrm{e}-11$ & 0.456 & 0.410 \\
\hline Albite & 49.9 & 424 & $1.47 \mathrm{e}-9$ & $1.74 \mathrm{e}-9$ & $1.44 \mathrm{e}-10$ & 0.442 & 0.410 \\
\hline Montmorillonite & 49.9 & 389 & $1.45 \mathrm{e}-10$ & $1.72 \mathrm{e}-10$ & $5.53 e-11$ & 0.464 & 0.410 \\
\hline $\begin{array}{l}\text { Hanford } \\
\text { Sediment }\end{array}$ & 40.3 & 476 & $6.21 \mathrm{e}-10$ & $7.07 \mathrm{e}-10$ & $3.81 \mathrm{e}-11$ & 0.459 & 0.303 \\
\hline Muscovite & 40.1 & 473 & $4.11 \mathrm{e}-10$ & $4.67 \mathrm{e}-10$ & $3.39 \mathrm{e}-11$ & 0.458 & 0.301 \\
\hline Kaolinite & 40.1 & 495 & $1.80 \mathrm{e}-10$ & $2.05 e-10$ & $2.17 \mathrm{e}-11$ & 0.456 & 0.301 \\
\hline Albite & 40.1 & 424 & $1.77 \mathrm{e}-10$ & $2.00 \mathrm{e}-10$ & $4.52 \mathrm{e}-11$ & 0.442 & 0.301 \\
\hline Montmorillonite & 40.1 & 389 & $7.96 \mathrm{e}-11$ & $9.08 \mathrm{e}-11$ & $2.19 \mathrm{e}-11$ & 0.464 & 0.301 \\
\hline $\begin{array}{l}\text { Hanford } \\
\text { Sediment } \\
\text { pH } 7.2\end{array}$ & 34.2 & 349 & $2.16 \mathrm{e}-10$ & $2.35 \mathrm{e}-10$ & $6.18 \mathrm{e}-11$ & 0.352 & 0.244 \\
\hline $\begin{array}{l}\text { Montmorillonite } \\
\text { pH } 7.2\end{array}$ & 34.2 & 348 & $4.55 \mathrm{e}-10$ & $5.00 \mathrm{e}-10$ & $5.87 e-11$ & 0.409 & 0.244 \\
\hline $\begin{array}{l}\text { Hanford } \\
\text { Sediment }\end{array}$ & 30.1 & 476 & $8.21 \mathrm{e}-11$ & $9.00 \mathrm{e}-11$ & $1.72 \mathrm{e}-11$ & 0.459 & 0.209 \\
\hline Muscovite & 30.1 & 473 & $7.71 \mathrm{e}-11$ & $8.44 \mathrm{e}-11$ & $1.27 \mathrm{e}-11$ & 0.458 & 0.208 \\
\hline Kaolinite & 30.1 & 495 & $5.31 \mathrm{e}-11$ & $5.81 \mathrm{e}-11$ & $1.02 \mathrm{e}-11$ & 0.456 & 0.208 \\
\hline Albite & 30.1 & 424 & $3.89 \mathrm{e}-11$ & $4.24 \mathrm{e}-11$ & $5.79 \mathrm{e}-12$ & 0.442 & 0.208 \\
\hline Montmorillonite & 30.1 & 389 & $3.20 \mathrm{e}-11$ & $3.40 \mathrm{e}-11$ & $2.40 \mathrm{e}-11$ & 0.464 & 0.208 \\
\hline $\begin{array}{l}\text { Hanford } \\
\text { Sediment } \\
\text { pH } 7.2\end{array}$ & 30.9 & 349 & $1.51 \mathrm{e}-10$ & $1.63 \mathrm{e}-10$ & $3.21 \mathrm{e}-11$ & 0.352 & 0.215 \\
\hline $\begin{array}{l}\text { Montmorillonite } \\
\text { pH } 7.2\end{array}$ & 30.9 & 348 & $3.36 \mathrm{e}-10$ & $3.65 \mathrm{e}-10$ & $9.83 e-11$ & 0.409 & 0.215 \\
\hline $\begin{array}{l}\text { Hanford } \\
\text { Sediment } \\
\text { pH } 7.2\end{array}$ & 24.9 & 349 & $6.13 e-11$ & $6.49 \mathrm{e}-11$ & $3.18 \mathrm{e}-11$ & 0.352 & 0.168 \\
\hline $\begin{array}{l}\text { Montmorillonite } \\
\text { pH } 7.2\end{array}$ & 24.9 & 348 & $2.28 \mathrm{e}-10$ & $2.43 e-10$ & $6.76 \mathrm{e}-11$ & 0.409 & 0.168 \\
\hline $\begin{array}{l}\text { Hanford } \\
\text { Sediment }\end{array}$ & 20.3 & 476 & $2.53 e-11$ & $2.69 \mathrm{e}-11$ & $8.39 \mathrm{e}-12$ & 0.459 & 0.136 \\
\hline Muscovite & 20.3 & 473 & $1.21 \mathrm{e}-11$ & $1.29 \mathrm{e}-11$ & $1.08 \mathrm{e}-11$ & 0.458 & 0.136 \\
\hline Kaolinite & 20.3 & 495 & $1.17 \mathrm{e}-11$ & $1.24 \mathrm{e}-11$ & $8.30 \mathrm{e}-12$ & 0.456 & 0.136 \\
\hline Montmorillonite & 20.3 & 389 & $3.20 \mathrm{e}-11$ & $3.40 \mathrm{e}-11$ & $2.40 \mathrm{e}-11$ & 0.464 & 0.136 \\
\hline $\begin{array}{l}\text { Hanford } \\
\text { Sediment } \\
\text { pH } 7.2\end{array}$ & 20.0 & 349 & $3.10 \mathrm{e}-11$ & $3.25 \mathrm{e}-11$ & $2.74 \mathrm{e}-11$ & 0.352 & 0.134 \\
\hline $\begin{array}{l}\text { Montmorillonite } \\
\text { pH } 7.2\end{array}$ & 20.0 & 348 & $1.52 \mathrm{e}-10$ & $1.61 \mathrm{e}-10$ & $9.76 \mathrm{e}-11$ & 0.409 & 0.134 \\
\hline
\end{tabular}




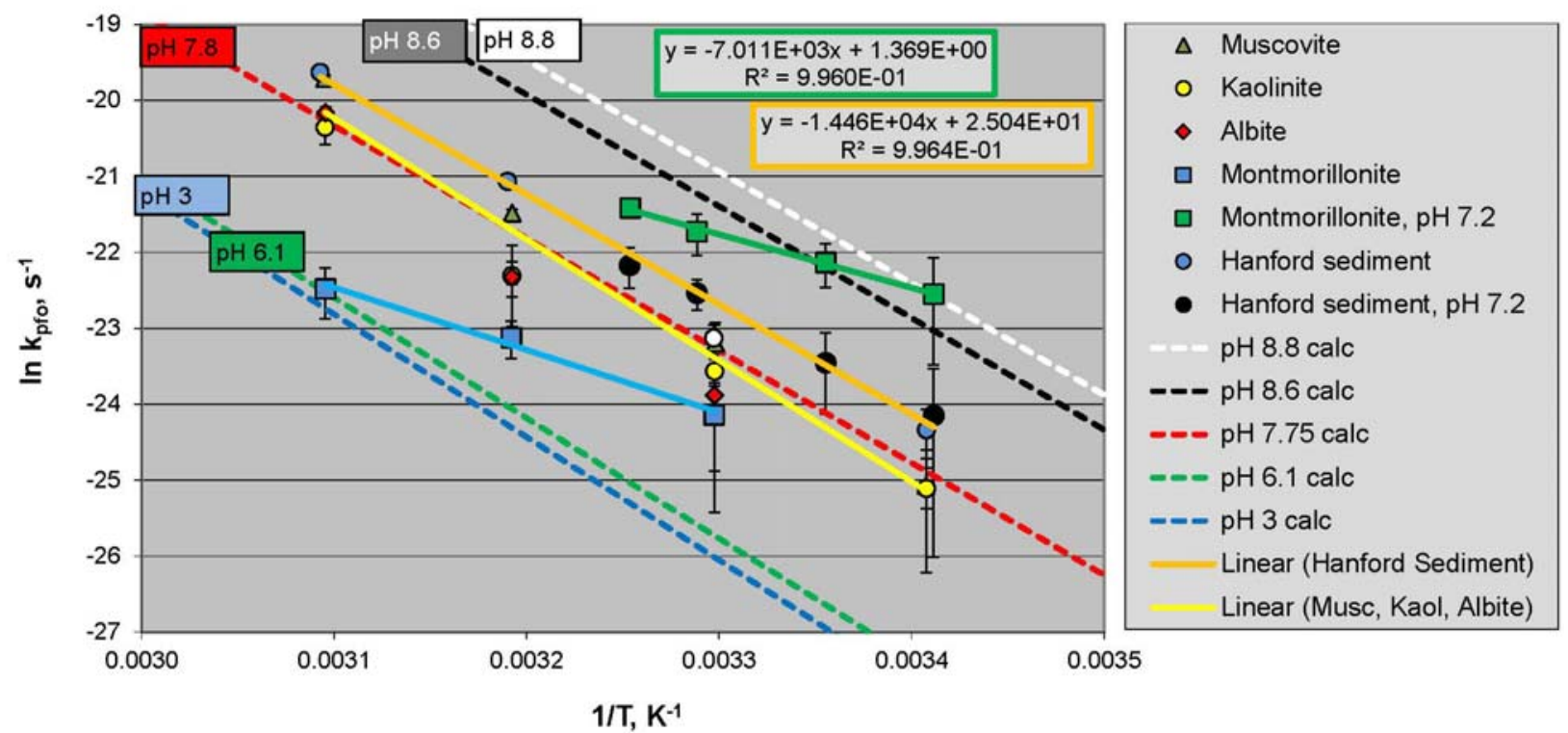

Figure 4.7. Arrhenius Plot of Observed Pseudo-First-Order Rate Data $\left(\mathrm{k}_{\mathrm{pfo}}\right)$ for Hydrolysis of Chloroform in Suspensions of Minerals or Hanford Sediment and Calculated for Homogeneous Solutions at Several pH Levels. White circle is datum not included in Arrhenius regression for Hanford sediment. Error Bars are 95\% Confidence Intervals.

units was recorded, and this mineral also yielded the largest decrease in hydrolysis rate. The $\mathrm{pH}$ of a suspension of the original montmorillonite in deionized water at the same concentration was 6.1.

Comparison of the heterogeneous rate constant data with that plotted for homogeneous solutions of known $\mathrm{pH}$ values adds further insight into the role of the solid phase in CF hydrolysis. The muscovite, albite, and kaolinite all yielded rates slower than would be expected for a homogeneous solution at $\mathrm{pH}$ 8.6, but agreed almost exactly what would be expected for $\mathrm{pH} 7.75$, the actual $\mathrm{pH}$ of the groundwater before degassing. These minerals would have very limited $\mathrm{pH}$ buffering capacities due to their low specific surface areas and thus would readily conform to the $\mathrm{pH}$ of the solution as observed in the $\mathrm{pH}$ testing described in the previous paragraph.

In contrast, the montmorillonite, which has a specific surface at least two orders of magnitude greater than that of the other minerals, and a correspondingly large exchange capacity for cations (including protons or hydronium ions) would be expected to buffer the solution $\mathrm{pH}$ much as a weak-acid might. The roughly similar apparent activation energies observed for the montmorillonite before and after equilibration at $\mathrm{pH} 7.2$ reflect this buffering capability, as protons would be expected to desorb from the montmorillonite as temperature increased and thereby slow CF hydrolysis. The huge difference in hydrolysis rates observed for the original $(\mathrm{pH} \mathrm{6.1)}$ ) and pre-equilibrated ( $\mathrm{pH}$ 7.2) montmorillonite experiments suggest that the initial sorbed proton status is very important, in analogy with the $\mathrm{pH}$ observed when adding the free-acid form of a weak acid or a mixture of free-acid and ionized forms to a solution. What is curious, however, is that after pre-equilibration at $\mathrm{pH} 7.2$, the montmorillonite yielded $\mathrm{CF}$ rate constants at room temperature similar to what would be expected for a homogeneous solution $\mathrm{pH}$ of $8.6-8.8$, much higher than the nominal $\mathrm{pH}$ of the equilibration. Perhaps the lateral edge sites of 
montmorillonite provide reactive sites that promote hydrolysis of CF well above that expected for the average bulk solution $\mathrm{pH}$ maintained by the mineral.

Lastly, we note that the Hanford sediment contains about $30 \%$ smectite $(21 \%$ in the clay-size fraction, the remainder an indeterminate mixture of 2:1 layer silicates such as smectite, chlorite and vermiculite in the silt size fraction). Montmorillonite is a common type of smectite. Hanford sediment rate constants are consistently faster than those of the other minerals, but slower than those obtained with pure montmorillonite pre-equilibrated to $\mathrm{pH}$ 7.2. However, Hanford sediment does not show much evidence for proton release at higher temperatures as the apparent activation energy $\left(120 \mathrm{~kJ} \mathrm{~mol}^{-1}\right)$ is similar to that of the comparable homogeneous solution at $\mathrm{pH} 7.8\left(123 \mathrm{~kJ} \mathrm{~mol}^{-1}\right)$. It is also probable that the smectite adsorbs chloroform on portions of its surface that are hydrophobic. The potential consequences of such a reaction are beyond the scope of this discussion.

Regardless of the exact mechanisms involved, the main insight to be gained from the data in Figure 4.7 is simply that the solid phases seem to act as $\mathrm{pH}$ buffers that can have significant effects on $\mathrm{CF}$ hydrolysis rates. Further research into this phenomenon is needed to develop a mechanistic understanding of the rate at which CF hydrolyzes in Hanford and other sediments. 



\subsection{Summary Discussion}

During the project, a total of 114 experiments were successfully conducted, with several dozen more having been initiated. These experiments have provided data to calculate 106 robust rate constants under a variety of temperatures and other experimental conditions. A signature product of this project is the development of a ZHR at SUNY-Cortland that eliminates uncertainty associated with headspace corrections, allows multiple sampling of the same solution during a run, and yields highly reproducible results.

In general, the homogeneous data for CT obtained in this study are of high quality and show conclusively that the rates of hydrolysis at groundwater temperatures are significantly slower (by a factor of 3.5 at $16^{\circ} \mathrm{C}$ ) than predicted by extrapolations from high-temperature studies. There is no difference in rate between deionized $\mathrm{H}_{2} \mathrm{O}$ and Hanford groundwater, nor is there substantive evidence for an effect of Hanford sediment or pure mineral phases on hydrolysis of CT. Most of the robust rate constants measured for the heterogeneous systems are fully consistent with the homogeneous data, and all are within the $95 \%$ confidence belt bracketing the Arrhenius regression line for the homogeneous data.

A more complicated situation is encountered with hydrolysis of $\mathrm{CF}$, due to the presence of parallel pathways, neutral and base-catalyzed. The neutral pathway is consistent, very slow, and the dominant path at pHs of 6 and below. The base-catalyzed path requires hydroxyl ions, is dominant above $\mathrm{pH} 8$, and can be extremely effective at higher pHs.

Nucleophiles other than water and hydroxyl ion include monohydrogen phosphate ions and bicarbonate ions. Homogeneous base-catalyzed hydrolysis rates for CF are different for phosphatebuffered systems than for systems where hydroxide is the only base present. The differences are attributed to parallel hydrolysis reactions caused by the nucleophilic character of the phosphate anions, particularly $\mathrm{HPO}_{4}{ }^{2-}$. Although the activation energies in the phosphate buffers are higher than in $\mathrm{NaOH}$, the rates observed are similar at groundwater temperatures. It is surmised that neither phosphate nor $\mathrm{HCO}_{3}{ }^{-}$, which is common in groundwater and has a nucleophilic character comparable to $\mathrm{HPO}_{4}{ }^{2-}$, significantly increases the rates of hydrolysis for $\mathrm{CF}$ over those observed in waters where they are absent.

The project developed sufficient rate data for neutral and base-catalyzed homogeneous hydrolysis of $\mathrm{CF}$ to calculate the relative impacts of temperature and $\mathrm{pH}$ on $\mathrm{CF}$ hydrolysis rates, and to estimate the rate at any given combination of these factors within the ranges tested. For example, the estimated half-life of $\mathrm{CF}$ in $\mathrm{pH}-7.8$ Hanford groundwater at $16^{\circ} \mathrm{C}$ is 3400 years. An increase in $\mathrm{pH}$ of about one unit or an increase in temperature of about $15^{\circ} \mathrm{C}$ will decrease the hydrolysis half-life of CF by an order of magnitude. Similar rate data can be applied to hydrolysis of CT to show the effect of temperature. The estimated half-life of CT in aqueous systems at $16^{\circ} \mathrm{C}$ is 630 years. An increase in temperature of about $13^{\circ} \mathrm{C}$ can decrease the half-life by an order of magnitude.

Applications of this knowledge to site remediation are obvious. The reported hydrolysis rates can be used to evaluate degradation processes as part of the natural attenuation of CT and CF in the aquifer. Of interest, is the clear evidence for heterogeneous effects on CF hydrolysis. These effects likely stem from the $\mathrm{pH}$ buffering capacities of minerals, which vary substantially. The clear role of smectite as a $\mathrm{pH}$ buffer offers exciting possibilities for understanding how CF hydrolyzes in sediments of different mineralogy. It is also possible that CF sorbs to smectite (Riley et al. 2005) and this may be an important 
factor that also needs exploration. In relation to active remediation, manipulations to increase subsurface temperatures, even if only by a few tens of ${ }^{\circ} \mathrm{C}$, would have a huge impact on the hydrolysis rates of CT and $\mathrm{CF}$ and yield relatively benign products $(\mathrm{CO}$ and $\mathrm{HCl})$ at the ppm level.

At SUNY-Cortland, liquid-vapor partition coefficients $\left(\mathrm{K}_{\mathrm{lv}}\right)$ for $\mathrm{CT}$ and CF were measured at the temperatures and CF concentrations used in our homogeneous hydrolysis experiments. A smaller set of $\mathrm{K}_{\mathrm{lv}}$ values for CT determined at PNNL by an entirely different approach were in excellent agreement with the SUNY data. Although at near-ambient temperatures good agreement with published values for the Henry's law constant $\left(\mathrm{K}_{\mathrm{h}}\right)$ was obtained, our CT values displayed a substantially weaker temperature dependence. Our assessment, based on the excellent agreement in $\mathrm{K}_{\mathrm{lv}}$ values determined by complementary techniques, and the excellent agreement in measured rate constants when these values are used to correct for headspace effects in the ampule experiments to the zero-headspace results measured directly, is that development of bulk pressures inside the sealed ampules leads to a different partitioning behavior that is not captured by Henry's law constants. Unfortunately, limited resources did not permit further work in this area, particularly for $\mathrm{CF}$, but it is something that needs refinement for use in future laboratory studies with volatile organic compounds. 


\subsection{References}

Amonette JE, PM Jeffers, O Qafoku, CK Russell, DR Humphreys, TW Wietsma, and MJ Truex. $2010 \mathrm{~b}$. Abiotic Degradation Rates for Carbon Tetrachloride and Chloroform: Progress in FY 2010. PNNL20044, Pacific Northwest National Laboratory, Richland, Washington.

Amonette JE, PM Jeffers, O Qafoku, CK Russell, TW Wietsma, and MJ Truex. 2008. Abiotic Degradation Rates for Carbon Tetrachloride and Chloroform: Progress in FY 2008. PNNL-18020, Pacific Northwest National Laboratory, Richland, Washington.

Amonette JE, PM Jeffers, O Qafoku, CK Russell, TW Wietsma, and MJ Truex. 2009. Carbon Tetrachloride and Chloroform Attenuation Parameter Studies: Heterogeneous Hydrolytic Reactions. PNNL-18735, Pacific Northwest National Laboratory, Richland, Washington.

Amonette JE, PM Jeffers, O Qafoku, CK Russell, TW Wietsma, and MJ Truex. 2010a. Abiotic Degradation Rates for Carbon Tetrachloride and Chloroform: Progress in FY 2009. PNNL-19142, Pacific Northwest National Laboratory, Richland, Washington.

EPA, Ecology, and DOE-RL. 2008. Record of Decision, Hanford 200 Area 200-ZP-1 Superfund Site Benton County, Washington. U.S. Environmental Protection Agency, Region 10, Lacey, Washington; Washington State Department of Ecology, Olympia, Washington; U.S. Department of Energy, Richland Operations Office, Richland, Washington.

Gorgenyi M, J Dewulf, and H Van Langenhove. 2002. "Temperature dependence of Henry's law constant in an extended temperature range." Chemosphere 48(7):757-762.

Gossett JM. 1987. "Measurement of Henry's law constants for $\mathrm{C}_{1}$ and $\mathrm{C}_{2}$ chlorinated hydrocarbons." Environmental Science \& Technology 21(2):202-208.

Gustafsson JP. 2012. Visual MINTEQ ver 3.0. Version compiled 18 October 2012 in Visual Basic .NET 2005 and downloaded 24 October 2012 from

http://www2.lwr.kth.se/english/OurSoftware/vminteq/download.html KTH Royal Institute of Technology, Department of Land and Water Resources Engineering, Stockholm, Sweden.

Heron G, TH Christensen, and CG Enfield. 1998. "Henry's law constant for trichloroethylene between 10 and $95{ }^{\circ}$ C." Environ. Sci. Technol. 32(10):1433-1437.

Jeffers PM, C Brenner, and NL Wolfe. 1996. "Hydrolysis of carbon tetrachloride." Environmental Toxicology and Chemistry 15(7):1064-1065.

Jeffers PM, P Coty, S Luczak, and NL Wolfe. 1994. "Halocarbon hydrolysis rates - a search for ionic strength and heterogeneous effects." Journal of Environmental Science and Health, Part A 29(4):821831.

Jeffers PM, LM Ward, LM Woytowitch, and NL Wolfe. 1989. "Homogeneous hydrolysis rate constants for selected chlorinated methanes, ethanes, ethenes and propanes." Environmental Science \& Technology 23(8):965-969. 
McAuliffe CD. 1971. "GC determination of solutes by multiple phase equilibration." Chem. Tech. $1(1): 46-51$.

Oostrom M., ML Rockhold, PD Thorne, MJ Truex, GV Last, and VJ Rohay. 2007. "Carbon tetrachloride flow and transport in the subsurface of the 216-Z trench at the Hanford Site." Vadose Zone Journal 6(4):971-984.

Riley RG, DS Sklarew, CF Brown, PM Gent, JE Szecsody, AV Mitroshkov, and CJ Thompson. 2005. Carbon Tetrachloride and Chloroform Partition Coefficients Derived from Aqueous Desorption of Contaminated Hanford Sediments. PNNL-15239, Pacific Northwest National Laboratory, Richland, Washington.

Rorabacher DB. 1991. "Statistical treatment for rejection of deviant values: Critical values of Dixon's "Q" parameter and related subrange ratios at the 95\% confidence level." Anal. Chem. 63(2):139-146.

Schwarzenbach RP, PM Gschwend, and DM Imboden. 1993. Environmental Organic Chemistry. John Wiley \& Sons, New York.

Staudinger J and PV Roberts. 2001. “A critical compilation of Henry's law constant temperature dependence relations for organic compounds in dilute aqueous solutions." Chemosphere 44(4):561-576.

Swain CG and CB Scott. 1953. Quantitative correlation of relative rates. "Comparison of hydroxide ion with other nucleophilic reagents toward alkyl halides, esters, epoxides and acyl halides." Journal of the American Chemical Society 75(1):141-147.

Truex MJ, CJ Murray, CR Cole, RJ Cameron, MD Johnson, RS Skeen, and CD Johnson. 2001. Assessment of Carbon Tetrachloride Groundwater Transport in Support of the Hanford Carbon Tetrachloride Innovative Technology Demonstration Program. PNNL-13650, Pacific Northwest National Laboratory, Richland, Washington. 



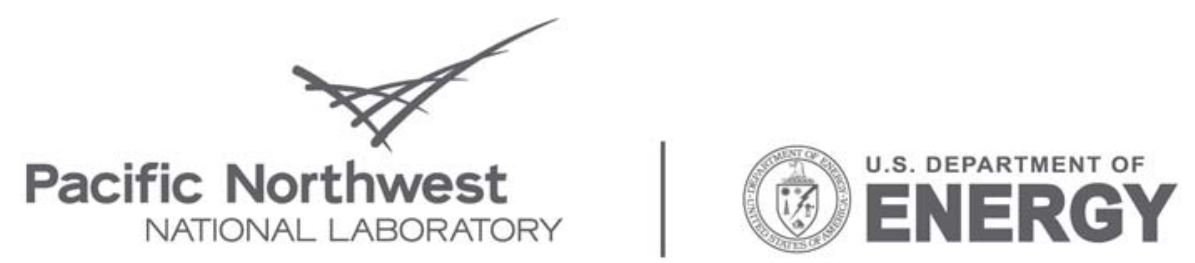

Proudly Operated by Battelle Since 1965

902 Battelle Boulevard

P.O. Box 999

Richland, WA 99352

1-888-375-PNNL (7665)

www.pnl.gov 